Universidade de Brasília

Faculdade de Medicina

Programa de Pós-Graduação

em Patologia Molecular

\title{
Expressão de fragmentos de anticorpos que reconhecem o antígeno CD20 humano.
}

\author{
Tarcila Zuleica Zaparolli Lopes
}

Orientadora: Prof. ${ }^{a}$ Dr. ${ }^{a}$ Andréa Queiroz Maranhão Co-Orientador: Prof. Dr. Marcelo de Macedo Brígido 
Universidade de Brasília

ii

Faculdade de Medicina

Programa de Pós-Graduação

em Patologia Molecular

\title{
Expressão de fragmentos de anticorpos que reconhecem o antígeno CD20 humano.
}

\author{
Tarcila Zuleica Zaparolli Lopes
}

Orientadora: Prof. ${ }^{\text {a }}$ Dr. ${ }^{\text {a }}$ Andréa Queiroz Maranhão

Co-Orientador: Prof. Dr. Marcelo de Macedo Brígido

Dissertação apresentada ao

Programa de Pós-Graduação

em Patologia Molecular da

Universidade de Brasília como

requisito parcial à obtenção do

grau de Mestra em Patologia

Molecular.

BRASÍLIA-DF 


\section{Banca Examinadora:}

Prof. Dr. Spartaco Astolfi Filho- UFAM

Membro Titular

Prof $^{\underline{a}}$ Dr ${ }^{\mathrm{a}}$ Kelly Grace Magalhães- UnB

Membro Titular

Prof $^{\underline{a}} \operatorname{Dr}^{\mathrm{a}}$ Andréa Queiroz Maranhão- UnB

Orientadora

Prof. Dr. Marcelo de Macedo Brígido- UnB

Co-orientador

Trabalho desenvolvido no Laboratório de Biologia

Molecular da Universidade de Brasília sob orientação da Prof ${ }^{a}$ Drª Andréa Queiroz Maranhão. 
Eu dedico esse trabalho a todos que acreditaram em mim! 
"No início, faça o imprescindível, depois o possivel, e de repente estará fazendo o impossível!" 


\section{AGRADECIMENTOS}

Primeiramente gostaria de agradecer a Deus por esta oportunidade!

Sou imensamente grata a minha orientadora Prof ${ }^{a} D r^{a}$ Andréa Queiroz Maranhão e ao meu co-orientador Prof. Dr. Marcelo de Macedo Brígido, pelos anos de orientação, companheirismo, apoio, paciência e confiança. Aprendi muito com vocês! Muito obrigada! Agradeço a minha mãe Elza Zaparolli Lopes e toda minha família pelo apoio, amor e carinho durante toda esta etapa! Agradeço as minhas amigas e amigos de Brasília e Votuporanga/SP, pela amizade, pelos momentos divertidos e pelo imenso apoio! Agradeço a todos os membros do Laboratório de Imunologia Molecular, pelo apoio, companheirismo e pelos conhecimentos compartilhados! Agradeço a todos os alunos, funcionários e professores do Laboratório de Biologia Molecular, pelo apoio, companheirismo e gentileza! Agradeço aos membros da banca pela atenção e pela oportunidade de compartilhar conhecimentos!

Agradeço ao Programa de Pós-Graduação em Patologia Molecular/UnB pelo apoio e gentileza!

Agradeço ao BNDES e ao Laboratório Cristália Produtos Químicos e Farmacêuticos Ltda, por apoiarem e patrocinarem o projeto: "ANTI-CD2O DESENVOLVIMENTO DE TECNOLOGIA DE ANTICORPOS ESPECÍFICOS PARA O ANTÍGENO LINFOCITÁRIO HUMANO CD20". 


\section{Sumário}

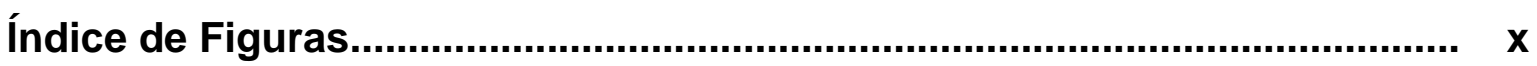

Índice de Tabelas................................................................................... xii

Lista de Abreviaturas............................................................................. xiii

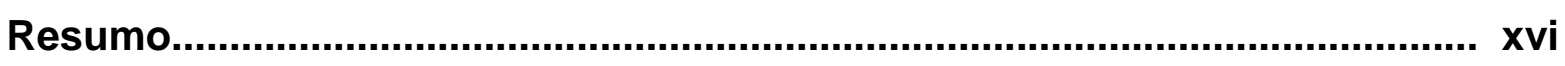

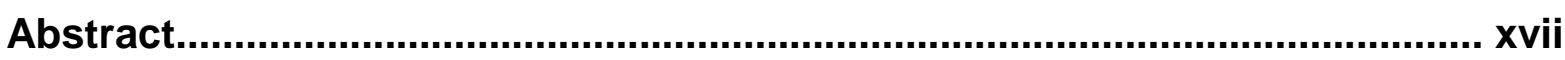

Introdução

1.1 Imunoterapia........................................................................... 2

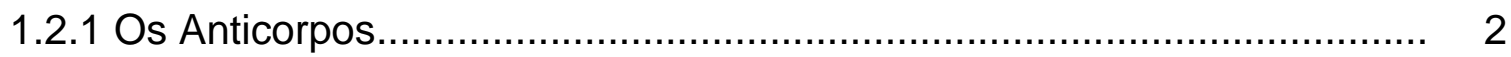

1.2.2 Anticorpos Monoclonais................................................................. 9

1.2.3 Engenharia e Humanização de anticorpos........................................... 10

1.3 Anticorpos de uso terapêutico......................................................... 14

$1.4 \mathrm{O}$ antígeno CD20 e os anticorpos anti-CD20 ....................................... 18

1.5 Expressão heteróloga de anticorpos.................................................. 26

1.6 Desenho gênico de versões humanizadas dos domínios variáveis leve e pesado do Rituximabe ........................................................................ 29

\section{Objetivos}

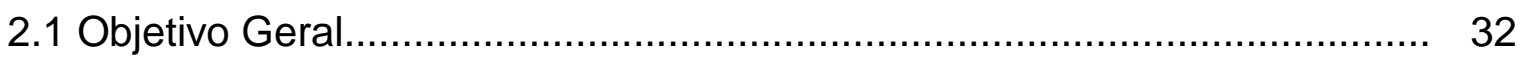

2.2 Objetivos Específicos.................................................................... 32

\section{Materiais e Métodos}

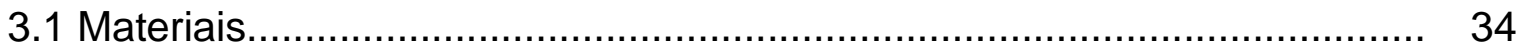

3.1.1 Linhagem de Bactéria.............................................................................. 34

3.1.2 Linhagem de Célula de Mamífero................................................................. 34

3.1.3 Meios de cultura e soluções para bactérias..................................................... 34

3.1.4 Meios de cultura e soluções para células de mamíferos.................................. 36

3.1.5 Soluções para extração de DNA plasmídial................................................... 37

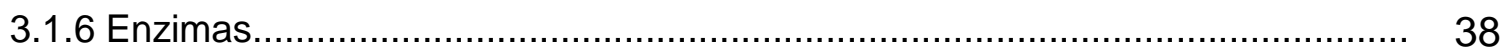

3.1.7 Soluções e reagentes para eletroforese em gel de agarose........................... 39

3.1.8 Oligonucleotídeos utilizados para confirmação das clonagens dos $\quad 39$ scFvs no vetor de expressão

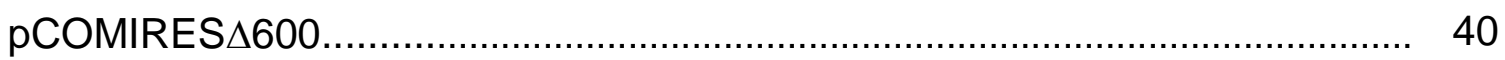


3.1.10 Marcadores moleculares para proteína................................................... 42

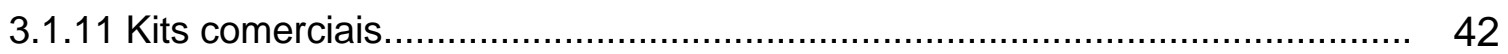

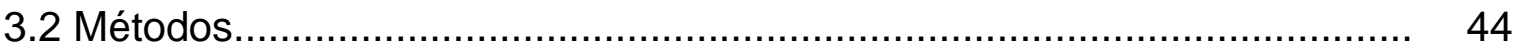

3.2.1 Extração de DNA plasmidial.................................................................... 44

3.2.2 Análise de DNA plasmidial por eletroforese em gel de agarose..................... 46

3.2.3 Digestão do DNA plasmidial com enzimas de restrição.................................. 47

3.2.4 Eletroeluição de fragmentos de DNA em gel de agarose com o kit comercial Ultrafree-DA Centrifugal Filter Unit (Millipore)................................................ 47

3.2.5 Precipitação de DNA utilizando glicogênio como carreador........................... 48

3.2.6 Ligação de fragmentos de DNA............................................................... 48

3.2.7 Preparação de células competentes e transformação bacteriana................... 49

3.2.8 Condições e preparo da Reação em Cadeia da Polimerase (PCR) ................ 51

3.2.9 Cultura de células de mamíferos................................................................. 52

3.2.10 Descongelamento de células $\mathrm{CHO}-\mathrm{K} 1$ e passagem de células..................... 53

3.2.11 Tripsinização, passagem das células e formação de monocamada celular.

3.2.12 Congelamento de células CHO-K1 - Criopreservação................................. 54

3.2.13 Determinação da viabilidade celular por meio da contagem em câmara de Neubauer

3.2.14 Estimativa do número de células por meio de contagem em câmara de Neubauer.

3.2.15 Transfecção de Células $\mathrm{CHO}$ utilizando o reagente JetPEI ${ }^{\mathrm{TM}}$ (Polyplus Transfection)

3.2.16 Seleção de células transfectadas utilizando Geneticina ${ }^{\circledR}$ (G418Sulfato)

3.2.17 Análises dos sobrenadantes de cultura em placas de microtitulação por meio de ELISA.

3.2.18 Purificação de Proteínas com a coluna His Trap da Ge HealthCare e concentração das amostras eluídas com a coluna Centricon da Millipore.

3.2.19 Análise de proteínas em gel de poliacrilamida desnaturante

3.2.20 Coloração do gel SDS- PAGE com o kit comercial Proteo Silver Stain da Sigma

3.2.21 Análise das proteínas recombinantes por Western Blot. 
Resultados e Discussão.

4.1 Clonagem dos scFv humanizados e murino no vetor de expressão pCOMIRES $\triangle 600$

4.2 Obtenção da população mista de clones estáveis de células CHO$\mathrm{K} 1$ produtores dos FvFcs recombinantes..

4.3 Produção e purificação das proteínas recombinantes

Conclusão.

Conclusão e Perspectivas............................................................. 81

Referências Bibliográficas........................................................................ 83 


\section{Índice de Figuras}

Figura 1 Representação esquemática de uma IgG Humana........................ 4

Figura 2 Diagrama esquemático do rearranjo dos segmentos gênicos que codificam para as cadeias leve e pesada..

Figura 3 Resumo esquemático das estratégias abordadas para engenharia de anticorpos.

Figura 4 Representação de uma molécula de imunoglobulina (lgG) em comparação com fragmentos gerados por técnicas do DNA recombinante (FvFc e scFv)

Figura 5 Demonstração esquemática da interação antígeno CD20 e os dois tipos de anticorpos anti- CD20: em A o tipo I e B o tipo II.

Figura 6 O epítopo descontínuo ao qual o Rituximab se liga, localiza-se dentro do domínio extracelular do CD20 humano.

Figura 7 Ontogenia da célula B, mostrando as linhagens de linfócitos que expressam o antígeno CD20

Figura 8 Mecanismos de ação propostos pelo Rituximab contra o antígeno CD20 humano

Figura 9 : Desenho esquemático do vetor pCOMIRES $\triangle 600$

Figura 10 Desenho esquemático da estratégia de clonagem com o vetor de expressão em células de mamíferos pCOMIRES $\triangle 600$

Figura 11 Desenho esquemático do vetor: pCOMIRES $\Delta 600$ com a versão humanizada scFv $A$ e análise comparativa do perfil de restrição em gel de agarose.

Figura 12 Desenho esquemático do vetor pCOMIRES $\Delta 600$ com a versão murina scFv O e análise comparativa do perfil de restrição em gel de agarose.

Figura 13 Desenho esquemático do vetor pCOMIRES $\Delta 600$ com a versão humanizada $s c F v L$ e análise comparativa do perfil de restrição em gel de agarose.

Figura 14 Desenho esquemático dos primers utilizados para a confirmação das clonagens por PCR

Figura 15 Análise em gel de agarose $1,5 \%$ com o resultado da PCR das 


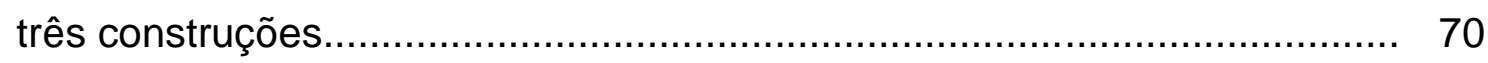

Figura 16 Gel SDS-PAGE mostrando as três construções, após os

processos de purificação................................................................... 76

Figura 17 Análise por Western Blot dos fragmentos FvFcs A, O e L, após

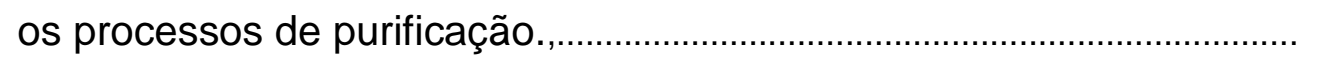

Figura 18 Capacidade de ligação á molécula CD20 das três construções

FvFcs em comparação com o anticorpo rituximabe. 


\section{Índice de Tabelas}

Tabela 1: Anticorpos monoclonais aprovados pela FDA até 2014

Tabela 2: Anticorpos anti- CD20 utilizados na clínica médica e aprovados pela FDA

Tabela 3: Oligonucleotídeos utilizados para confirmação das clonagens dos scFvs no vetor de expressão

Tabela 4: Quantificação estimada do total em $\mathrm{ng} / \mathrm{mL}$ referente ao acumulo de sobrenadante de cada garrafa da versão $O$

Tabela 5: Quantificação estimada do total $\mathrm{em} \mathrm{ng} / \mathrm{mL}$ referente ao acumulo de sobrenadante de cada garrafa da versão $A$.

Tabela 6:Quantificação estimada do total $\mathrm{em} \mathrm{ng} / \mathrm{mL}$ referente ao acumulo de sobrenadante de cada garrafa da versão 


\section{Lista de Abreviaturas}

ADCC do inglês Antibody Dependent Cell Mediated Cytotoxicity- Citotoxidade cellular dependente de anticorpo

ADCP do inglês Antibody-Dependent Cellular Phagocytosis - Fagocitose celular dependente de anticorpo.

$A m p^{R}$ - Gene de resistência à ampicilina ( $\beta$-lactamase)

C-Terminal - Extremidade carboxi - terminal

CDC do inglês Complement- Mediated Cytotoxicity -Citotoxidade dependente de complemento

cDNA - Ácido desoxirribonucléico complementar

CDR - Região determinante de complementariedade

$\mathrm{CH}$ - Cadeia constante pesada de anticorpo

$\mathrm{CHO}$ - Células de ovário de hamsterchinês

CL - Cadeia constante leve de anticorpo

CMV - citomegalovírus

$\mathrm{CO}_{2}$ - Dióxido de Carbono

$\mathrm{dH}_{2} \mathrm{O}$ - Água destilada

DMSO - Dimetilsulfóxido

DNA - Ácido desoxirribonucléico

dNTPs - mistura dos desoxirribonucleotídeos trifosfatados adenosina, citidina, guanosina e timidina.

dsDNA - DNA de fita dupla

EDTA - Ácido etilenodiaminotetracético

Fab - Fragmento (de anticorpo) de ligação ao antígeno

FACS - FluorescenceActivetedCellSorter

Fc - Fragmento (de anticorpo) cristalizável (porção constante)

FcR- Receptor de Fc

FDA - Food and Drug Administration (EUA)

FITC - Fluoresceína isotiocianato

FR - Arcabouço (Framework)

Fv - Fragmento (do anticorpo) varável

$g$ - Força gravitacional

g - Grama

HACA- do inglês, Human Anti-Chimeric Antibody

HAHA- do inglês Human Anti- Humanized Antibody 
HAMA- do inglês Human Anti-Murine Antibodies

Ig - Imunoglobulina

IL - Interleucina

$\mathrm{kb}$ - Kilobase

$\mathrm{kDa}$ - Kilodalton

L - Litro

M - Molar

$\mathrm{mA}$ - Miliampère

mAb - Anticorpo Monoclonal

mg - Miligrama

MM - Massa Molecular

$\mathrm{mM}$ - Milimolar

mRNA - Ácido ribonucléico mensageiro

ms - Milisegundo

C - Grau Celcius

OD - densidade óptica

OKT3 - Anticorpo monoclonal anti-CD3 clone OKT3

ori - Origem de replicação

$\mathrm{p}$ - Peso

$\mathrm{p} / \mathrm{v}$ - razão peso/volume

$\mathrm{pb}$ - Par de base

PBS - Tampão salina fosfato

PCD (do inglês Programmed Cell Death)- Morte Celular Programada

PCR - Reação em cadeia da polimerase (do inglês Polymerase Chain Reaction)

PDB - Protein Data Bank

PE - Ficoeritrina

PEG - Polietileno glicol

PMSF - Fluoreto de fenilmetilsulfonato

ptnA - Proteína A de Staphylococcus aureus

RNA - Ácido ribonucléico

RNAase - Ribonuclease

rpm - Rotações por minuto

scFv - Fragmento variável (de anticorpo) de cadeia única

SDS - Sódio Duodecil Sulfato

SFB - soro fetal bovino

TE - tampão Tris/EDTA 
Tris - Tri (hidroximetil) aminometano

$U$ - Unidade

UTR - Região não traduzida do gene

$\mathrm{V}-$ volts

v/v - razão volume/volume

VH - Domínio variável da cadeia pesada de um anticorpo

VL - Domínio variável da cadeia leve de um anticorpo

T - tempo de passagem da corrente elétrica

$\Omega$ - unidade de medida da resistência elétrica (ohm) 


\section{RESUMO}

Em 1997, foi aprovado especificamente para o tratamento de pacientes com LNH de baixo grau (folicular) ou linfomas foliculares agressivos non-Hodgkin, o anticorpo recombinante anti-CD20: Rituximabe (MabThera $\AA$, Rituxan). Esse anticorpo, causa uma depleção seletiva e transitória de ambas subpopulações de células B CD20 positivas, normais ou malignas, dentro de etapas chaves da ontogenia das células $B$. Neste trabalho, objetivou-se a expressão, produção e purificação de fragmentos de anticorpos na forma FvFc específicos para o antígeno humano CD20, por meio de células de ovário de hamster chinês versão K1 (CHO-K1). Foram selecionadas duas versões scFvs humanizadas, contendo as CDRs do anticorpo monoclonal quimérico Rituximabe e uma versão $\mathrm{scFv}$ murina similar ao anticorpo original. Posteriormente, essas versões foram transferidas para o vetor de expressão em células de mamíferos pCOMIRES $\triangle 600$. Esse vetor possui os genes que codificam os domínios $\mathrm{CH} 2 \mathrm{e}$ $\mathrm{CH} 3$ do fragmento cristalizável de imunoglobulina humana IgG, de forma que a proteína liberada pela célula de mamífero corresponda ao fragmento FvFc do anticorpo. Após a finalização das etapas de clonagens, as células $\mathrm{CHO}-\mathrm{K} 1$ foram utilizadas como sistema de expressão e produção de anticorpos. Essas células foram mantidas na presença do antibiótico geneticina para a seleção da população mista de células $\mathrm{CHO}-\mathrm{K} 1$ produtoras dos FvFcs recombinantes. Os sobrenadantes de cultura foram avaliados quanto á presença de FvFc por meio de imunodetecção ELISA. Posteriormente, foram submetidos a uma cromatografia de afinidade, utilizando a coluna HITRAP protein A HP. Após a purificação as frações coletadas da coluna, foram analisadas quanto ao grau de pureza destes fragmentos por meio do gel SDS-PAGE e Wersten-Blot. Com esses resultados foi possível realizar análises da capacidade de ligação das proteínas recombinantes por meio de citometria de fluxo. Os resultados também sugerem que é possível propor avaliações das proteínas recombinantes quanto à estabilidade conformacional, e em relação as funções efetoras realizadas pelo rituximabe. 


\begin{abstract}
In 1997 was approved specifically for treating patients with low-grade NHL (follicular) or aggressive follicular non-Hodgkin lymphomas, anti-CD20 recombinant antibody: Rituximab (MabThera, Rituxan). This antibody causes a selective and transient depletion of both subpopulations of CD20 positive, normal or malignant, within key steps of B cell ontogeny This study aimed to expression, production and purification of antibody fragments in the form FvFc specific to human CD20 antigen, using Chinese hamster ovary cells version K1 (CHO-K1). Two versions of humanized scFvs were selected, containing the CDRs of the chimeric monoclonal antibody Rituximab and a scFv version similar to the original murine antibody. Subsequently, these versions were transferred to the expression vector into mammalian cells pCOMIRES $\Delta 600$. This vector has the gene encoding the $\mathrm{CH} 2$ and $\mathrm{CH} 3$ domains of the crystallizable fragment of human immunoglobulin IgG, so that the protein released from the mammalian cell FvFc corresponds to the fragment of the antibody. After completion of cloning steps, the $\mathrm{CHO}-\mathrm{K} 1$ cells were used as expression system and production of antibodies. These cells were maintained in the presence of the antibiotic geneticin for selecting the mixed population of $\mathrm{CHO}-\mathrm{K} 1$ cells producing the recombinant FvFcs. The culture supernatants were evaluated for the presence of FvFc by immunodetection ELISA. Subsequently, they were subjected to affinity chromatography using a HiTrap Protein A HP column. After purification the fractions collected from the column were analyzed for purity of these fragments by means of SDS-PAGE and gel blot Wersten. With these results it was possible to perform analyzes of the binding capacity of the recombinant proteins by flow cytometry. The results also suggest that it is possible to propose reviews of recombinant proteins for the conformational stability, and for the effector functions performed by rituximab.
\end{abstract}


Introducão 


\subsection{Imunoterapia}

O sistema imunológico exerce mecanismos fisiológicos determinados a manter a homeostasia, a defesa e a vigilância do organismo. Podendo atuar contra patógenos, identificar e tentar destruir qualquer substância exógena que possa ser considerada "estranha", discriminar o próprio e o não próprio, promover a especificidade, e exercer diferentes propriedades relacionadas com a adaptação e memória (Litman et al., 2010).

Embora a resposta imune seja um mecanismo defensor evoluído nos vertebrados, em nenhum indivíduo ela pode ser considerada totalmente perfeita em relação a todas as suas propriedades (Litman et al., 2010). Atualmente, a imunoterapia é uma das alternativas para aperfeiçoar tais mecanismos, uma vez que, tem como finalidade promover ou inibir as respostas imunes (Bornstein et. al., 2010).

Inúmeros são os desafios da medicina contemporânea, dentre os quais destacam-se: prover um tratamento menos "invasivo" a pacientes com tumores, administrar fármacos de alta especificidade em pacientes com doenças auto-imunes ou rejeição a transplantes. Atualmente a imunoterapia é considerada um tratamento promissor para diversas patologias envolvendo disfunções do sistema imune, infecções e neoplasias (Bornstein et. al., 2010).

Os anticorpos recombinantes podem resolver problemas de difícil solução, como por exemplo, o ataque de células cancerígenas (Robak e Robak, 2011). Diferente do soro o anticorpo monoclonal, consiste em uma preparação homogênea monoespecífica capaz de reconhecer um único alvo (Maranhão e Brígido, 2001).

Um dos êxitos da imunoterapia no tratamento do câncer é a administração do anticorpo recombinante Rituximabe (MabThera, Rituxan) em pacientes com linfomas foliculares ou agressivos non-Hodgkin (Bornstein et. al., 2010).

\subsubsection{Os Anticorpos}

Um dos principais mecanismos fisiológicos do sistema imune humoral é a produção de glicoproteínas solúveis por células B. Essas proteínas são denominadas anticorpos (Ac) ou imunoglobulinas (lg), possuem uma massa 
molecular em torno de $150 \mathrm{kDa}$, e podem estar presentes na superfície da membrana do linfócito B ou serem secretadas por linfócitos no estágio de diferenciação terminal (Davies e Metzger, 1983). São compostas por dois tipos de cadeias polipeptídicas: cadeia pesada ( $\mathrm{H}$ do inglês heavy) e cadeia leve ( $\mathrm{L}$ do inglês light) sendo que, cada imunoglobulina possui duas destas cadeias as quais formam tetrâmeros (Stanfield et.al., 1990). Estes tetrâmeros perfazem três fragmentos com tamanhos aproximadamente iguais (Figura 1), sendo dois fragmentos ligadores de antígeno (Fab) e um terceiro fragmento que induz a atividade efetora do sistema imune, também conhecido como fragmento cristalizável (Fc) (Stanfield et.al., 1990).

As cadeias $\mathrm{H}$ e $\mathrm{L}$ formam a unidade básica das moléculas de imunoglobulinas, possuem pontes dissulfeto (ligações bissulfídicas) e interações não covalentes, sendo que, a quantidade destas interações varia entre os diferentes tipos de anticorpo (Davies e Metzger, 1983). As cadeias pesada e leve e as duas cadeias pesadas são mantidas juntas por pontes dissulfeto intercadeia e por interações não covalentes (Stanfield et.al., 1990). Há também, pontes dissulfeto dentro de cada uma das cadeias polipeptídicas, essas ligações bissulfídicas intercadeias criam os domínios de imunoglobulina, caracterizados pela estrutura de sete folhas-B-pregueadas conectadas por voltas (loops) do anticorpo (Stanfield et.al., 1990).

Estas ligações bissulfídicas, estão presentes em intervalos regulares de aproximadamente 100-110 aminoácidos formando um domínio globular compacto em cada alça nas cadeias polipeptídicas covalentes. Logo, cada cadeia $L$ apresenta dois domínios, enquanto que cada cadeia $\mathrm{H}$ consiste em quatro ou cinco domínios separados por uma curta região flexível. Além da união entre as diferentes cadeias por meio das pontes dissulfeto, os domínios juntam-se em pares por meio de interações hidrofóbicas não covalentes (Stanfield et.al., 1990).

As cadeias leves e pesadas podem ser divididas em duas regiões com base na variabilidade da sequência de resíduos de aminoácidos: regiões amino-terminais variáveis e regiões carboxi-terminais constantes. As regiões constantes estão presentes na cadeia leve e na cadeia pesada de forma desigual (Figura 1), a cadeia leve tem um domínio carboxi-terminal constante CL1, enquanto que a cadeia pesada possui três ou quatro: $\mathrm{CH} 1, \mathrm{CH} 2, \mathrm{CH} 3$ e $\mathrm{CH} 4$. Os domínios $\mathrm{CH} 2, \mathrm{CH} 3$ e $\mathrm{CH} 4$ da cadeia pesada formam a região cristalizável $(F c)$ que recruta e interage com 
componentes efetores do sistema imune. Já o primeiro domínio constante das cadeias $\mathrm{H}$ e $\mathrm{L}$ executa interações biológicas, porque estão presentes no fragmento Fab da imunoglobulina juntamente com a região variável (Brodsky, 2009).

Os domínios amino-terminais variáveis das cadeias $\mathrm{He} \mathrm{L}$, fragmento variável $(\mathrm{Fv})$, representam a parte da molécula do anticorpo que se liga ao determinante antigênico, o epítopo (Brodsky, 2009). Nas extremidades do domínio N-terminal destas cadeias existem ilhas hipervariáveis (Figura 1), também conhecidas como regiões determinantes de complementariedade (CDRs) (Bassing et.al., 2002). Estas regiões hipervariáveis, consistem em uma sequencia de aproximadamente 110 aminoácidos com elevadas taxas de variabilidade, as quais conferem especificidade a um anticorpo e são denominadas como: CDR1, CDR2 e CDR3 (Gelert, 2002). Juntas, as CDRs formam o paratopo, sítios de ligação ao antígeno, que correspondem a uma superfície complementar ao epítopo. Dentre as três regiões hipervariáveis, a CDR3 é a região determinante de complementariedade com maior variabilidade de resíduos de aminoácidos (Jung, 2004).

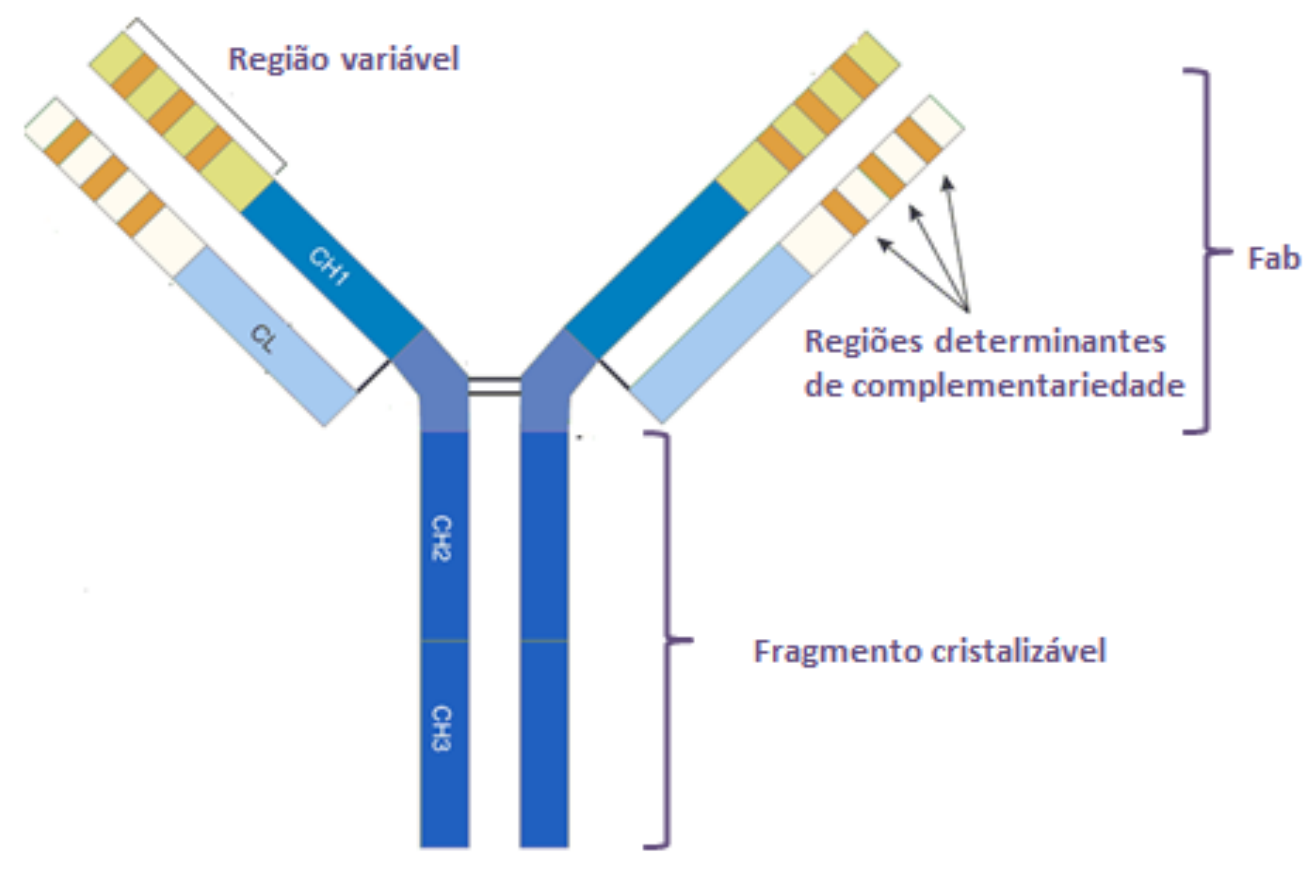

Figura 1. Representação esquemática de uma IgG humana. Em azul escuro, as regiões constantes da cadeia pesada. Em azul claro, as regiões constantes da cadeia leve. Em verde, região variável da cadeia pesada (VH). Em branco, região variável da cadeia leve (VL). Linhas laranjas, CDRs - regiões determinantes de complementaridade. Adaptada de (Brodsky, 2009). 
As atividades biológicas executadas pelas imunoglobulinas dependem das suas estruturas que definem os isótipos (classes). As cadeias $L$ são classificadas em $\kappa$ ou $\lambda$, de acordo com as regiões constantes carboxi- terminais que as compõem. Já as cadeias pesadas diferem umas das outras em relação ao conteúdo de carboidrato, tamanho, e classe (isótipos). A classificação da cadeia $\mathrm{H}$ tem como base as regiões constantes, as quais conferem diferentes funções biológicas a cada isótipo: $\mu, \varepsilon, \alpha, \gamma, \delta$ (Brodsky, 2009).

No organismo humano os plasmócitos, linfócitos que se diferenciaram, secretam anticorpos dos seguintes isótipos: $\lg \mathrm{M}, \lg \mathrm{E}, \lg \mathrm{A}, \lg \mathrm{G}$ e $\lg \mathrm{D}$. A $\lg \mathrm{A}$ é o principal anticorpo presente em secreções externas, e impede a ligação do patógeno com a superfície do epitélio. A lgD está presente na superfície das células $B$ e, assim como a lgE, é encontrado no soro em baixos títulos (Brodsky, 2009). A imunoglobulina IgE é encontrada na superfície de mastócitos e basófilos e exerce importantes atividades nas infecções helmínticas recrutando eosinófilos, e também promovendo a liberação de mediadores inflamatórios (Honjo et.al., 2002).

A imunoglobulina $\lg G$ é relevante nas respostas imunes secundárias muito comum e abundante sendo, inclusive, predominante entre os anticorpos de uso terapêutico. Este anticorpo é dividido em quatro subclasses: $\lg G 1$, IgG2, lgG3 e IgG4 (Brodsky, 2009).

Em mamíferos, os progenitores linfóides iniciais e as células tronco hematopoiéticas contém na sua configuração herdada genes organizados em seguimentos que codificam as cadeias leve e pesada das imunoglobulinas (Schatz e Ji, 2011). Nesta configuração (Figura 2), os loci destas cadeias têm em comum, múltiplos genes de regiões variáveis $(\mathrm{V})$, um ou alguns genes de regiões constantes (C) e, entre os genes $\mathrm{V}$ e $\mathrm{C}$ segmentos gênicos de junção $(\mathrm{J})$ compostos por várias porções pequenas de nucleotídeos (Papavasiliou et.al., 2002). Os genes que codificam a região variável da cadeia pesada de imunoglobulina, além de possuírem os seguimentos $\mathrm{V}$ e $\mathrm{J}$, também utilizam o seguimento de diversidade (D) enquanto que a região variável da cadeia leve conta com os seguimentos $V$ e J (Schatz e Ji, 2011).

Existe a possibilidade de serem formadas cerca de $10^{3}$ cadeias leves e $10^{4}$ cadeias pesadas diferentes. Visto que cada uma é formada independente da outra, cerca de $10^{7}$ tipos de imunoglobulinas podem ser criadas a partir da união das 
cadeias leve e pesada na célula (Bassing et.al., 2002). Para tanto (Figura 2), dois eventos genéticos estão envolvidos na síntese das cadeias de imunoglobulina: a organização e o rearranjo dos genes das cadeias leve e pesada e, a regulação da expressão dos genes de imunoglobulinas (Papavasiliou et.al., 2002). A organização e o rearranjo dos segmentos gênicos $\mathrm{V}$ e $\mathrm{J}$ (cadeia leve) ou VDJ (cadeia pesada) é também conhecida como recombinação somática. Este processo é mediado pela ação de recombinases e, pelas proteínas gênicas ativadoras de recombinase que reconhecem as sequências de DNA as quais flanqueiam todos os segmentos gênicos V, D e J (Schatz e Ji, 2011).

Sendo assim, uma molécula de imunoglobulina é formada a partir de dois genes criados durante a fase antígeno-independente do desenvolvimento do linfócito B. Embora existam duas cópias cromossômicas da cadeia $\mathrm{H}$ em cada célula, somente uma poderá ser expressa de forma funcional. Dessa forma, a regulação da expressão dos genes de imunoglobulina é relevante para que cada célula B produza um anticorpo de uma única especificidade antigênica (Schatz e Ji, 2011). 


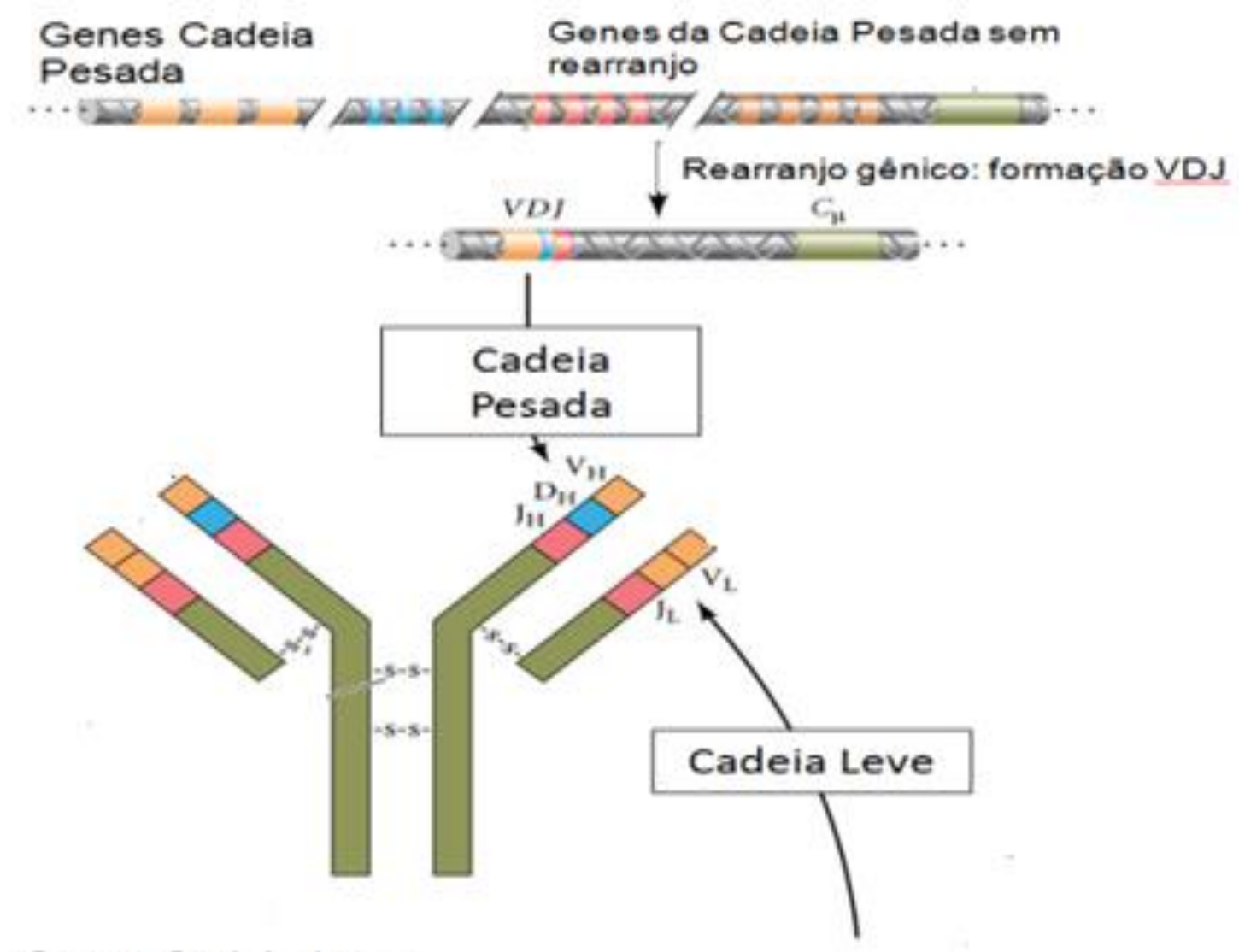

Genes Cadeia Leve

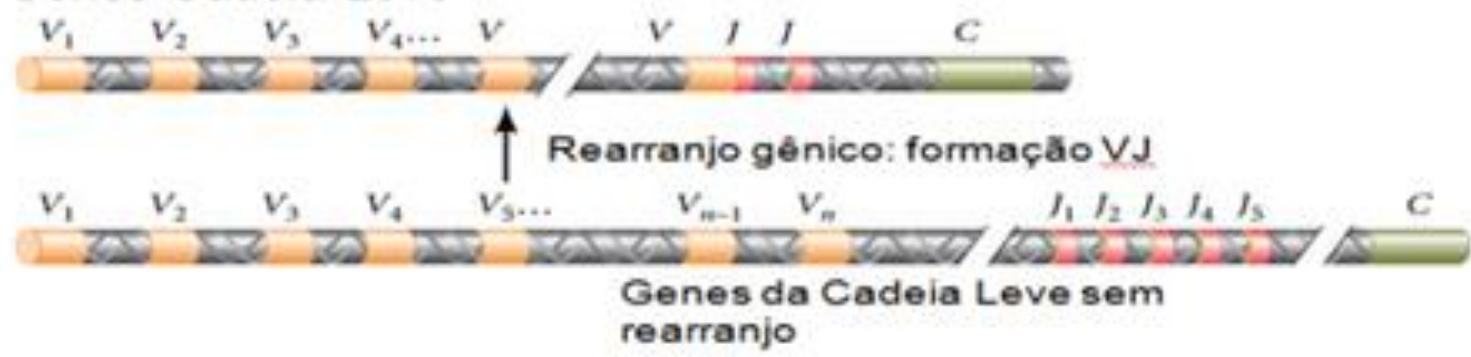

Figura 2. Diagrama esquemático do rearranjo dos segmentos gênicos que codificam para as cadeias leve e pesada. Adaptada de (Gilbert, 2006).

Os eventos genéticos da síntese das cadeias de imunoglobulina e a geração da diversidade das imunogloulinas contribuem para a formação do imenso repertório de linfócitos B capazes de lidar com um universo de epítopos diferentes (Bassing et.al., 2002). Outro mecanismo responsável pela síntese de um grande número de imunoglobulinas diferentes de forma que cada uma atue de forma específica para um determinado epítopo é, a troca de isótipo das imunoglobulinas. A troca de isótipo, ou troca de classe, consiste na sobreposição de rearranjos de DNA que 
justapõe os genes VDJ rearranjados a um gene diferente na região $C$ da cadeia pesada. Este evento ocorre em células B maduras e não altera a especificidade antigênica (Schatz e Ji, 2011).

Nas imunoglobulinas, a região de ligação ao antígeno forma uma superfície plana capaz de acomodar muitas formas diferentes, sendo assim as imunoglobulinas são capazes de se ligar a uma ampla variedade00 de antígenos, incluindo macromoléculas e moléculas químicas (Jung et.al., 2004). A força com a qual um anticorpo se liga à superfície de um epítopo é denominada: interação de afinidade (De Franco et.al., 2000). A repetida estimulação antigênica aumenta a afinidade de um anticorpo, sendo denominada maturação de afinidade (De Franco et.al., 2000).

A maturação de afinidade, é outro evento genético possível no linfócito $B$, deve-se aos pontos de mutação nas regiões $V$ ocorrendo quando as células $B$ ativadas migram para os folículos linfóides formando centros germinativos (De Franco et.al., 2000). Ou seja, é possível que durante a vida do linfócito B ele produza uma variedade de imunoglobulinas devida a mutações que podem ocorrer nos genes $\mathrm{V}$ das cadeias pesadas e/ou leves, sendo que, a sequência de aminoácidos desses anticorpos gerados por causa de um segundo estímulo é similar a sequência codificada devido ao primeiro estímulo (Niiro et.al., 2002). Esta mudança de resíduos de aminoácidos aumenta a variedade dos anticorpos e ocorre por um tempo limitado, sendo denominada: hipermutação somática (Niiro et.al., 2002).

Porém, apesar da afinidade ao mesmo antígeno, a maioria das imunoglobulinas presentes no soro não são idênticas entre si, e são derivadas de diferentes linhagens de células B. Logo, esta produção de anticorpos é definida como policlonal e nem sempre reprodutível na clínica médica, porque esses anticorpos não se direcionam ao mesmo epítopo (Brodsky, 2009).

Com base nestes conhecimentos, na década de 1970 os pesquisadores Milstein e Kohler desenvolveram um dos mais importantes avanços tecnológicos em imunologia: a geração de anticorpos monoclonais. Este foi um grande salto quanto ao poder de resolução e discriminação de anticorpos, porque diferente dos anticorpos policlonais os monoclonais são idênticos e capazes de reconhecer o mesmo epítopo (Kohler e Milstein, 1975). 


\subsection{2- Anticorpos monoclonais}

Os anticorpos monoclonais (mAc) consistem em populações homogêneas de anticorpos, produzidos por uma única célula $B$ imortalizada selecionada a partir da hibridização de uma célula $B$ do baço de um animal imunizado por um determinado antígeno com células de mielomas (tumores de plasmócitos) (Maranhão e Brígido, 2002).

Milstein e Kohler selecionaram uma população de células de mieloma, incapazes de produzir imunoglobulinas e a enzima HGPRT, e fusionaram com as células do baço de um camundongo recém imunizado. A mutação na linhagem celular do mieloma que impedia essas células de produzirem a enzima HGPRT (hipoxantina- guanina- fosforribosil transferase), não permitia que essas células sobrevivessem em cultura quando eram adicionadas drogas que inibem a síntese de purinas e timidilato, síntese de DNA, como a aminopterina presente no meio HAT (hipoxantina, amnopterina e timidina). No caso, a fusão ou hibridização, entre as células tumorais e os linfócitos $B$ do baço de um camundongo imunizado, gerava hibridomas e, também permitia a sobrevivência das células fusionadas em meio HAT, uma vez que as células $B$ do animal imunizado expressavam a enzima HGPRT normalmente. (Kohler e Milstein, 1975).

O êxito desta hibridização experimental deve-se ao fato dos linfócitos $B$, provenientes do baço do camundongo, serem HGPRT+e produtores de imunoglobulinas. A partir de uma população de hibridomas, uma célula híbrida pode ser selecionada e clonada originando uma população de células que secretam anticorpos idênticos com a mesma especificidade para um determinado epítopo (Kohler e Milstein, 1975).

Atualmente, os anticorpos monoclonais são protagonistas nos testes diagnósticos específicos e na imunoterapia. No entanto, para que esses anticorpos monoclonais chegassem à clínica médica diversas abordagens em engenharia genética foram utilizadas fazendo com que essas imunoglobulinas provenientes de camundongo tivessem resultados clínicos consistentes. Porque, apesar do alto poder de resolução e discriminação dos anticorpos monoclonais, o fato de, na maioria dos casos, serem gerados por camundongos, torna limitante a sua administração contínua em humanos. Esta limitação se dá pelo fato do sistema 
imunológico reconhecer essas imunoglobulinas de caráter murino como estranhas e, produzir a resposta HAMA (do inglês Human Anti-Murine Antibodies) (Maranhão e Brígido, 2002).

A resposta HAMA, também conhecida como doença do soro, consiste em uma reação de hipersensibilidade (tipo III), na qual os pacientes produzem anticorpos contra proteínas e complexos imunes compostos pelos anticorpos injetados. Os imunocomplexos ficam depositados nos vasos sanguíneos, rins e articulações, levando a superprodução de citocinas ("chuva de citocinas"), inflamação, glomerulonefrite e artrite. Outro efeito deletério da resposta HAMA é a rápida remoção do anticorpo monoclonal que é neutralizado por anticorpos de classe IgM e IgG produzidos pelo paciente, devido a grande quantidade de resíduos murinos (Holliger e Hudson, 2005).

A humanização de anticorpos foi a responsável por tornar o quadro favorável para a utilização dos anticorpos monoclonais na clínica. O objetivo de humanizar anticorpos,é fazer com que o anticorpo exerça suas funções na forma de uma estrutura discreta, não induzindo respostas imunes significativas, sendo assim, ele passaria pelas demais células como uma estrutura protéica comum (o que será mais difícil se ele tiver grandes fragmentos protéicos de origem murina). Este processo também resguarda a especificidade e afinidade da imunoglobulina (Maranhão e Brígido, 2002).

\subsection{3- Engenharia e Humanização de Anticorpos}

O potencial terapêutico do uso de anticorpos monoclonais tem sido explorado pelas empresas farmacêuticas. Investimentos e novos projetos estruturais melhoraram a farmacocinética in vivo (Figura 3), gerando uma ampla variedade de moléculas modificadas capazes de reconhecer um amplo repertório imune e se direcionar contra alvos refratários e proteínas complexas (Marszal e Fowler, 2012).

A inovadora tecnologia do DNA recombinante tem melhorado a eficiência clínica dos mAbs murinos, a primeira estratégia para reduzir a imunogenicidade foi a produção de mAbs quiméricos (Marszal e Fowler, 2012). O processo de quimerização envolve a fusão gênica da porção Fab do anticorpo murino ao fragmento cristalizável $(\mathrm{Fc})$ de uma imunoglobulina humana, formando uma quimera 
(Figura 3) (Maranhão e Brígido, 2002). Apesar deste processo reduzir a imunogenicidade e melhorar o mecanismo efetor do biofármaco, a permanência da fração Fab murina na molécula têm provocado, em pelo menos $9 \%$ dos pacientes, a resposta HACA (do inglês, Human Anti-Chimeric Antibody) (Weiner et. al., 2010). Similar à resposta HAMA, a resposta HACA inviabiliza a utilização dos anticorpos de uma forma repetitiva, uma vez que o paciente passa a produzir imunoglobulinas das classes lgG e lgM contra as versões de anticorpos quiméricos, provocando a sua neutralização e podendo resultar na doença do soro (Weiner et. al., 2010).

Diante destas evidências, foi proposto que a humanização de anticorpos deveria diminuir a quantidade de resíduos de aminoácidos murinos, aumentando a estrutura humana da molécula. Com a finalidade de reduzir ao máximo a quantidade destes resíduos e preservar a função do anticorpo, surgiu a técnica CDR grafting (transplante de CDR). Por meio de manipulação gênica, esta técnica permite que as três CDRs murinas permaneçam em um arcabouço (framework) humano, no caso, a estrutura de uma Fv (Weiner et. al., 2010). Sendo assim, as regiões amino- terminais variáveis das cadeias leve e pesada são redesenhadas de forma homóloga a imunoglobulina do camundongo, propiciando 0 transplante das sequências codificadoras das CDRs murinas. Para finalizar a construção do anticorpo humanizado, uma porção constante humana é fusionada a Fv humanizada (Figura 3) (Presta, 2008).

Outras técnicas também podem ser abordadas para transplantar as CDRs do anticorpo murino, tais como: a escolha de sequências germinais, best fit e resurfacing. A técnica de resurfacing substitui apenas os resíduos acessíveis ao reconhecimento dos anticorpos, porque ficam expostos ao solvente. A técnica best fit ou "melhor encaixe" consiste na escolha das sequências humanas que melhor se assemelham as sequências murinas, hipermutadas, não necessariamente germinais. A seleção das sequencias germinais tem como base o princípio das técnicas best fit e CDR grafiting, porém somente as sequencias germinais são analisadas como arcabouço, uma vez que acredita-se que essas sequencias possuem menor imunogenicidade porque estão presentes em linfócitos B imaturos e não passaram pelo processo de hipermutação somática (Presta, 2008).

O reconhecimento pelo sistema imune das CDRs murinas dos anticorpos humanizados, ou qualquer outro fragmento de anticorpo murino presente no 
arcabouço do anticorpo, resultando na resistência a terapia é denominada: resposta HAHA (do inglês Human Anti- Humanized Antibody). Embora rara, a resposta HAHA é possível e provoca as mesmas sintomatologias das respostas HACA e HAMA (Weiner et. al., 2010).

Diversas estratégias (Figura 3) para a produção de anticorpos terapêuticos totalmente humanos estão sendo desenvolvidas. São exemplos: a seleção a partir de bibliotecas de fragmentos de anticorpos humanos por phage display, e a utilização de camundongos transgênicos produtores de anticorpos humanos. A técnica de transgênia em camundongos permite a substituição dos loci de imunoglobulina murina por imunoglobulina humana resultando na produção de anticorpos monoclonais humanos (Krauss, 2003).

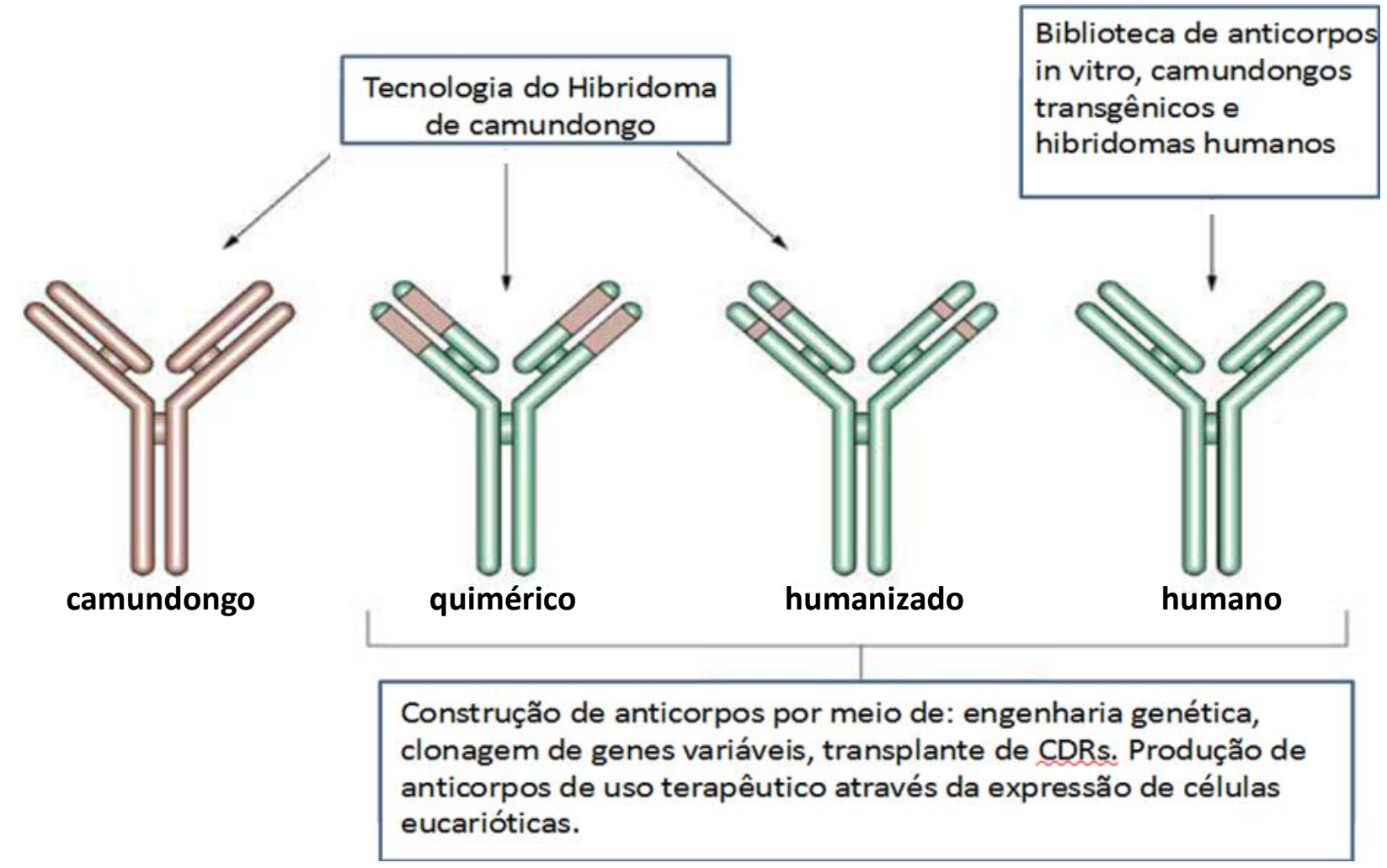

Figura 3: Resumo esquemático das estratégias abordadas para engenharia de anticorpos. Adaptada de (Sevastsyanovich et.al., 2009).

A possibilidade de dividir a molécula de imunoglobulina em diversos fragmentos (humanos ou humanizados) também é uma alternativa para diminuir a imunogenicidade (Andrade et.al., 2000). Foi isolado e caracterizado o fragmento de 
ligação ao antígeno (Fab), que pode ser clivado proteolíticamente com papaína e ser desmembrado da fração Fc. Este fragmento pode ser quimicamente modificado, melhorando suas propriedades de retenção e de internalização, sendo vantajoso no tratamento de patologias onde a função efetora do anticorpo não se faz necessária (Fang et.al., 2011).

Outra abordagem similar capaz de otimizar essas vantagens é a manipulação gênica para a construção do fragmento scFv (Andrade et.al., 2000). O fragmentoscFv (Figura 4) ou fragmento variável de cadeia única (do inglês single chain Fv) é composto pelas regiões variáveis das cadeias leves e pesadas unidas por um polipeptídeo conector composto por aminoácidos hidrofílicos que conferem flexibilidade a estrutura protéica $\left(\mathrm{Gly}_{4} \mathrm{Ser}\right)_{3}$, por exemplo. Este fragmento interage com o antígeno e não possui os domínios constantes $\mathrm{CH} 1, \mathrm{CH} 2, \mathrm{CH} 3$ e CL1 (Figura 4). No caso, nestas construções a molécula tem que ter alta afinidade ao epítopo, porque sua remoção da circulação sanguínea será mais rápida (Andrade et.al., 2005).

Porém, um anticorpo capaz de recrutar as funções efetoras do sistema imune e também ser removido rapidamente da circulação sanguínea, pode ser mais eficaz em algumas doenças (Bornstein et.al., 2009). O fragmento Fc é extremamente relevante para recrutar essas funções efetoras. Outra vantagem do fragmento Fc foi demonstrada por Andrade e colaboradores por meio de análises termodinâmicas e experimentos in vitro utilizando agentes desnaturantes. Eles mostraram que 0 fragmento FvFc possui maior estabilidade conformacional que o scFv uma vez que a presença dos domínios carboxi-terminais conferem esta estabilidade. Estes fragmentos (Figura 4) contém regiões variáveis das cadeias leve e pesada (fragmento Fv) essenciais à especificidade do anticorpo, as quais são formadas por um único cistron que confere uma estequiometria correta dessas cadeias (Andrade et.al., 2005). Estes fragmentos são obtidos a partir do fragmento scFv fusionado aos domínios $\mathrm{CH} 2$ e $\mathrm{CH} 3(\mathrm{Fc})$, preservando o sítio de glicosilação (Fang et.al., 2011). 


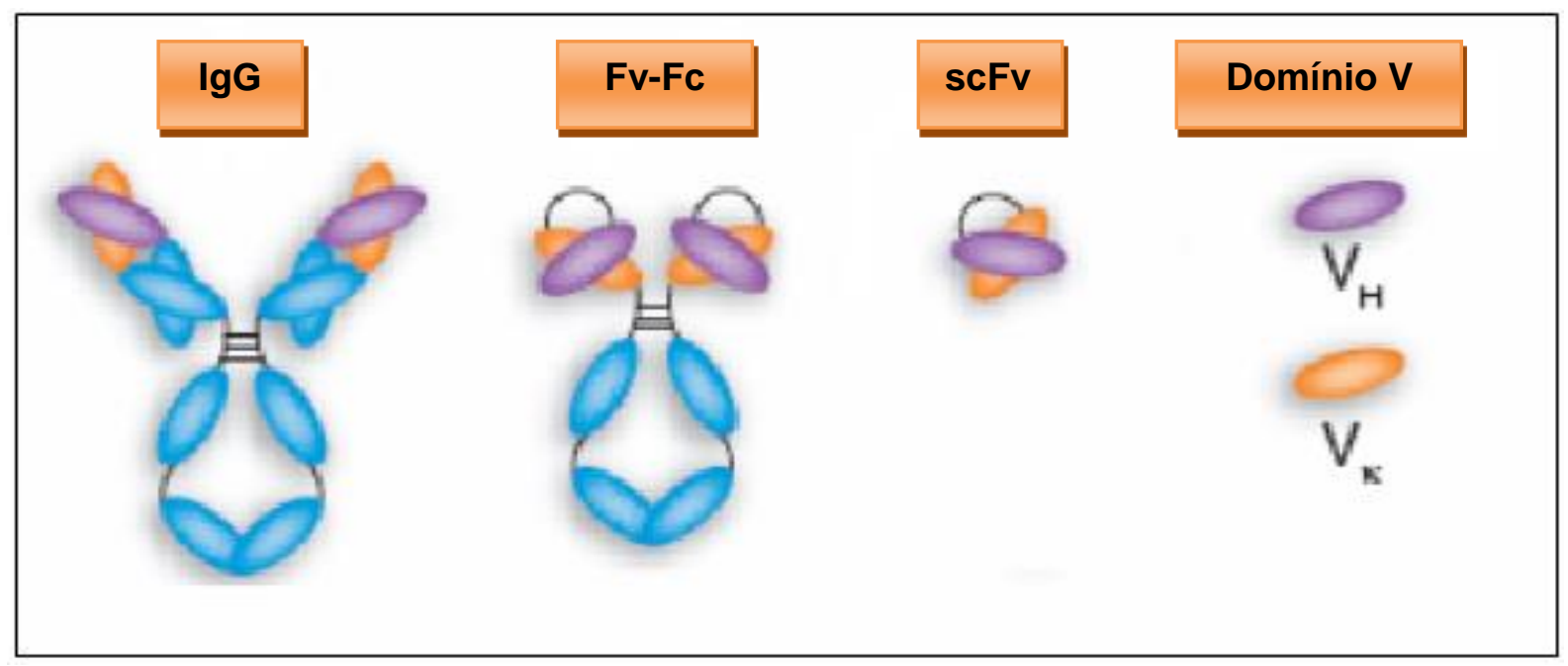

Figura 4: Representação de uma molécula de imunoglobulina (IgG) em comparação com fragmentos gerados por técnicas do DNA recombinante (FvFc e scFv). Adaptada de (Holliger e Hudson, 2005).

Várias estratégias podem ser abordadas para modificar os fragmentos de anticorpos, melhorando as suas propriedades em comparação a molécula progenitora. Todas elas dependem de inúmeros fatores, tais como: a densidade e a acessibilidade dos epítopos, estudos cristalográficos, a flexibilidade conformacional do alvo e os módulos de ligação ao antígeno. Analisando estas condições e através da estrutura tridimensional proposta, é possível, também, conjugar quimicamente diferentes moléculas nos fragmentos de imunoglobulinas. Um exemplo, é a construção de um scFvCD20Cys humano que foi conjugado a um micro RNA não codificador com atividade repressora, o antagomiR155. Este biofármaco não encontra- se disponível para uso clínico, porém os resultados farmacocinéticos são consistentes e confirmam a entrega e a função eficiente tanto do single chain quanto do micro RNA não codificador aos seus respectivos alvos (Wang et.al., 2014).

\subsection{Anticorpos de uso terapêutico}

A utilização de anticorpos monoclonais (mAbs) para fins terapêuticos têm solucionado muitos problemas no tratamento de várias patologias. A tecnologia do hibridoma desenvolvida por Milstein e Kohler forneceu bases teóricas para que em 1986, o primeiro anticorpo monoclonal fosse aprovado pela FDA- do inglês Food and Drug Administration- o Orthoclone OKT3. Esta preparação homogênea 
monoespecífica é capaz de reconhecer um único alvo: a molécula de CD3 humana presente no complexo receptor da célula $T$. Este anticorpo murino foi utilizado para redução de rejeição a transplantes (Silva et.al., 2009).

Assim como o OKT3, vários outros mAbs de origem murina foram aperfeiçoados por técnicas de engenharia genética para diminuir os efeitos colaterais sem afetar a especificidade do biofármaco. Diversos mAbs têm sido aprovados pela FDA: em 1997 o primeiro anticorpo humanizado pela técnica de transplante de CDR foi aprovado para uso clínico, o anti-IL2R Zenapax®, PDL (Vicent, 1998). Em 2002, utilizando-se a técnica de phage display um anticorpo totalmente humano foi aprovado, o anti-TNF $\alpha$ Humira Abbott (Measi, 2005). Em 2006, foi aprovado o primeiro anticorpo monoclonal produzido por camundongo transgênico, o Panitumumabe (utilizado no tratamento para câncer coloretal) (Gibson et. al., 2006).

Essas inovações tecnológicas perfazem uma das áreas de maior crescimento na indústria farmacêutica atual, a tabela 1 mostra os anticorpos monoclonais aprovados pela FDA (Food Drug Administration).

Tabela 1. Anticorpos monoclonais aprovados pela FDA até 2014*.

\begin{tabular}{|c|c|c|c|c|c|}
\hline Anticorpo & $\begin{array}{l}\text { Molécula } \\
\text { Alvo }\end{array}$ & Tipo & Indicação & Empresa & $\begin{array}{c}\text { Ano de } \\
\text { aprovaçãa }\end{array}$ \\
\hline $\begin{array}{c}\text { OKT3 } \\
\text { (Muromonab- } \\
\text { CD3) }\end{array}$ & CD3 & Murino & $\begin{array}{c}\text { Rejeição a } \\
\text { transplantes }\end{array}$ & Johnson \& Johnson & 1986 \\
\hline $\begin{array}{c}\text { Reopro } \\
\text { (Abciximab) }\end{array}$ & $\mathrm{CA} 17-1^{\mathrm{a}}$ & Quimérico & PTCA & Centocor & 1994 \\
\hline $\begin{array}{c}\text { Panorex } \\
\text { (Edrecolomab) }\end{array}$ & GPIIb/IIla & Quimérico & $\begin{array}{l}\text { Câncer } \\
\text { Coloretal }\end{array}$ & Centocor & 1995 \\
\hline $\begin{array}{c}\text { Rituxan } \\
\text { (Rituximab) }\end{array}$ & CD20 & Quimérico & $\begin{array}{l}\text { Linfoma Non- } \\
\text { Hodgkin }\end{array}$ & $\begin{array}{l}\text { Biogen } \\
\text { IDEC }\end{array}$ & 1997 \\
\hline $\begin{array}{c}\text { Zenapax } \\
\text { (Daclizumab) }\end{array}$ & IL2R & Humanizado & $\begin{array}{l}\text { Rejeição a } \\
\text { transplantes }\end{array}$ & Prot Design Labs & 1997 \\
\hline $\begin{array}{c}\text { Simulect } \\
\text { (Basiliximab) }\end{array}$ & IL2R & Quimérico & $\begin{array}{l}\text { Rejeição a } \\
\text { transplantes }\end{array}$ & Novarts & 1998 \\
\hline
\end{tabular}




\begin{tabular}{|c|c|c|c|c|c|}
\hline $\begin{array}{c}\text { Synagis } \\
\text { (palivizumab) }\end{array}$ & RSV F & Humanizado & Profilaxia de RSV & Medlmmune & 1998 \\
\hline $\begin{array}{l}\text { Remicade } \\
\text { (Infliximab) }\end{array}$ & TNF- $\alpha$ & Quimérico & $\begin{array}{l}\text { Artrite reumatóide e } \\
\text { doença de Crohn }\end{array}$ & Centocor & 1998 \\
\hline $\begin{array}{c}\text { Herceptin } \\
\text { (Trastuzumab) }\end{array}$ & Her2/neu & Humanizado & $\begin{array}{c}\text { Metástase de } \\
\text { câncer de mama }\end{array}$ & Genentech & 1998 \\
\hline $\begin{array}{c}\text { Mylotarg } \\
\text { (Gemtuzumab) }\end{array}$ & CD33 & Humanizado & Leucemia mielóide & Wyeth & 2000 \\
\hline $\begin{array}{c}\text { Campath } \\
\text { (Alemtuzumab) }\end{array}$ & CD52 & Humanizado & Leucemia linfocítica & $\begin{array}{l}\text { Millennium/ } \\
\text { ILEX }\end{array}$ & 2001 \\
\hline $\begin{array}{c}\text { Zevalin } \\
\text { (lbritumomab) }\end{array}$ & CD20 & Murino & $\begin{array}{c}\text { Linfoma Non- } \\
\text { Hodgkins }\end{array}$ & $\begin{array}{l}\text { Biogen } \\
\text { IDEC }\end{array}$ & 2002 \\
\hline $\begin{array}{c}\text { Humira } \\
\text { (Adalimumab) }\end{array}$ & TNF- $\alpha$ & Humano & $\begin{array}{c}\text { Artrite } \\
\text { reumatóide,doença } \\
\text { de Crohn }\end{array}$ & Abbott & 2002 \\
\hline $\begin{array}{c}\text { Xolair } \\
\text { (Orlalizumab) }\end{array}$ & $\lg E$ & Humanizado & Asma & Genentech & 2003 \\
\hline $\begin{array}{c}\text { Bexxar } \\
\text { (Tositumomab- } \\
\text { I131) }\end{array}$ & CD20 & Murino & $\begin{array}{l}\text { Linfoma Non- } \\
\text { Hodgkins }\end{array}$ & Corixa & 2003 \\
\hline $\begin{array}{c}\text { Raptiva } \\
\text { (Efalizumab) }\end{array}$ & CD11a & Humanizado & Psoríase & Genentech & 2003 \\
\hline $\begin{array}{c}\text { Erbitux } \\
\text { (Cetuximab) }\end{array}$ & EGFR & Quimérico & Câncer coloretal & Imclone Systems & 2004 \\
\hline $\begin{array}{c}\text { Avastin } \\
\text { (Bevacizumab) }\end{array}$ & VEGF & Humanizado & $\begin{array}{c}\text { Câncer coloretal, } \\
\text { renal }\end{array}$ & Genentech & 2004 \\
\hline $\begin{array}{c}\text { Tysabri } \\
\text { (Natalizumab) }\end{array}$ & $\begin{array}{l}\text { Integrina } \\
\text { A4 }\end{array}$ & Humanizado & $\begin{array}{c}\text { Doença de crohn, } \\
\text { esclerose }\end{array}$ & $\begin{array}{l}\text { Biogen } \\
\text { IDEC }\end{array}$ & 2004 \\
\hline $\begin{array}{c}\text { Lucentis } \\
\text { (Renibizumab) }\end{array}$ & VEGF-A & Humanizado & $\begin{array}{c}\text { Degeneração } \\
\text { macular }\end{array}$ & Genentech & 2006 \\
\hline $\begin{array}{c}\text { Vectibix } \\
\text { (Panitumomab) }\end{array}$ & EGFR & Humano & Câncer coloretal & Amgen & 2006 \\
\hline $\begin{array}{c}\text { Soliris } \\
\text { (Eculizumab) }\end{array}$ & C5 & Humanizado & $\begin{array}{l}\text { Hemoglobinúria } \\
\text { (PNH) }\end{array}$ & Alexion Pharm & 2007 \\
\hline
\end{tabular}




\begin{tabular}{|c|c|c|c|c|c|}
\hline Milatuzumab & CD74 & Humanizado & $\begin{array}{c}\text { Mieloma múltiplo, } \\
\text { Linfoma Non- } \\
\text { Hodgkin }\end{array}$ & Immunomedics & 2008 \\
\hline $\begin{array}{c}\text { Cimzia } \\
\text { (Certolizumab) }\end{array}$ & Integrina & Humanizado & Doença de Crohn & $\begin{array}{l}\text { Biogen } \\
\text { IDEC }\end{array}$ & 2008 \\
\hline $\begin{array}{c}\text { Simponi } \\
\text { (Golimumab) }\end{array}$ & TNF- $\alpha$ & Humano & Artrite reumatoide & Johnson \& Johnson & 2009 \\
\hline $\begin{array}{c}\text { llaris } \\
\text { (Canakinumab) }\end{array}$ & IL-1 $\beta$ & Humano & CAPS & Novartis & 2009 \\
\hline $\begin{array}{c}\text { Stelara } \\
\text { (Ustekinumab) }\end{array}$ & $\begin{array}{c}\text { IL-12 e IL- } \\
23\end{array}$ & Humano & Psoríase & Johnson \& Johnson & 2009 \\
\hline $\begin{array}{c}\text { Arzerra } \\
\text { (Ofatumumab) }\end{array}$ & CD20 & Humano & $\begin{array}{l}\text { Leucemia linfocítica } \\
\text { crônica }\end{array}$ & Genmab & 2010 \\
\hline $\begin{array}{c}\text { Vedotin } \\
\text { (Brentuximab) }\end{array}$ & CD30 & Quimérico & Linfoma Hodgkin & Seatle Genetics & 2011 \\
\hline $\begin{array}{c}\text { Ipi } \\
\text { (Ipilimumab) }\end{array}$ & CTLA-4 & Humano & $\begin{array}{l}\text { Melanoma } \\
\text { metastático }\end{array}$ & Bristol & 2011 \\
\hline $\begin{array}{c}\text { Belimumab } \\
\text { (Benlysta) }\end{array}$ & BLyS & Humano lgG1 & $\begin{array}{l}\text { Lúpus Eritematoso } \\
\text { Sistêmico }\end{array}$ & $\begin{array}{c}\text { Human Genome } \\
\text { Sciences }\end{array}$ & 2011 \\
\hline $\begin{array}{c}\text { Brentuximab } \\
\text { vendontin } \\
\text { (Adcetris) }\end{array}$ & CD30 & $\begin{array}{l}\text { Quimérico lgG1; } \\
\text { imunoconjugado }\end{array}$ & $\begin{array}{c}\text { Linfoma de } \\
\text { Hodgkin, Linfoma } \\
\text { de grandes células } \\
\text { anaplásicas } \\
\text { sistêmicas }\end{array}$ & Seatle Genetics & 2011 \\
\hline $\begin{array}{c}\text { Pertuzumab } \\
\text { (Perjeta) }\end{array}$ & HER2 & $\begin{array}{l}\text { Humanizado } \\
\qquad \lg \mathrm{G} 1\end{array}$ & Cancer de mama & Genentech & 2012 \\
\hline $\begin{array}{c}\text { Raxibacumab } \\
\text { (Pending) }\end{array}$ & $\begin{array}{c}\text { B anthrasis } \\
\text { PA }\end{array}$ & $\begin{array}{l}\text { Humano } \\
\text { IgG1 }\end{array}$ & Infecção Antrax & $\begin{array}{c}\text { Human Genome } \\
\text { ieScnces }\end{array}$ & 2012 \\
\hline $\begin{array}{c}\text { Ado- } \\
\text { trastuzumab } \\
\text { entansine } \\
\text { (Kadcyla) }\end{array}$ & HER2 & $\begin{array}{c}\text { Humanizado } \\
\text { lgG1 } \\
\text { imunoconjugado }\end{array}$ & Câncer de mama & Genentech/ Roche & 2013 \\
\hline $\begin{array}{l}\text { Obinutuzumab } \\
\text { (Gazyva) }\end{array}$ & CD20 & $\begin{array}{l}\text { Humanizado } \\
\qquad \lg G 1\end{array}$ & $\begin{array}{c}\text { Leucemia } \\
\text { Linfocítica Crônica }\end{array}$ & Roche & 2013 \\
\hline
\end{tabular}




\begin{tabular}{|c|c|c|c|c|c|}
\hline $\begin{array}{l}\text { Siltuximab } \\
\text { (Sylvant) }\end{array}$ & IL-6 & Quimérico lgG1 & $\begin{array}{l}\text { Doença de } \\
\text { Castleman }\end{array}$ & Janssen Biotech & 2014 \\
\hline $\begin{array}{c}\text { Vedolizumab } \\
\text { (Entyvio) }\end{array}$ & $\begin{array}{c}\alpha 4 \beta 7 \\
\text { integrina }\end{array}$ & $\begin{array}{l}\text { Humanizado } \\
\qquad \lg \mathrm{G} 1\end{array}$ & $\begin{array}{l}\text { Colite ulcerativa e } \\
\text { Doença de Crohn }\end{array}$ & $\begin{array}{c}\text { Millennium } \\
\text { Pharmaceuticals/ } \\
\text { Takeda }\end{array}$ & 2014 \\
\hline $\begin{array}{c}\text { Ramucirumab } \\
\text { (Cyramza) }\end{array}$ & VEGFR2 & Humano lgG1 & Câncer Gástrico & ImClone Systems & 2014 \\
\hline
\end{tabular}

*Adaptada do site da Food Drug Administration

Disponível em: http://www.antibodysociety.org/news/approved_mabs.php

\subsection{0 antígeno CD20 e os anticorpos anti-CD20}

Os linfomas são neoplasias malignas que se originam nos linfonodos. Em 1832 o Dr.Thomas Hodgkin fez os primeiros diagnósticos de linfomas, descrevendoos como sendo formados por células mononucleadas, Linfomas de Hodgkin. Em 1900 a $\mathrm{Dr}^{\mathrm{a}}$ Dorothy Reed e o Dr Carl Sternberg observaram células B grandes e multinucleadas formando um complexo com as células mononucleadas, representando aproximadamente $1 \%$ do tumor, essas células são denominadas Reed-Sternberg (RS) e o complexo formado com as células mononucleares HRS. Posteriormente, outros pesquisadores descrevem que além das células HRS, são encontradas diversas células que infiltram o tumor, tais como linfócitos e histiócitos (van Oers e Kersten, 2011).

Todos os outros linfomas que não se enquadram neste padrão, são denominados Linfomas Non-Hodgkin (LNH). Uma vez que, os Linfomas de Hodgking são constituídos por células que perderam suas características de origem, ao contrário dos LNH que as mantêm em grande parte. Atualmente, Segundo a Organização Mundial de Saúde, a classificação dos Linfomas não-Hodgkin relaciona as características imunogenéticas, morfológicas e moleculares do tumor, as quais descrevem mais de 20 subtipos, em geral, $85 \%$ são de células B sendo raros os linfomas de células T (Marszal e Fowler, 2012).

Em 1980 surgiu o anti-CD20 B1, o primeiro anticorpo monoclonal para o 
tratamento do Linfoma Non- Hodgkin de células B capaz de reconhecer um antígeno presente e específico nesta célula, o antígeno CD20 humano (Fang et.al., 2011). Por ser um anticorpo monoclonal murino, o anti- CD20 B1 ou tositumomabe, não foi rapidamente aprovado para uso clínico. Nos anos seguintes os anticorpos antiCD20 foram geneticamente modificados para aplicação clínica, atualmente são classificados em tipos I e II (Ernest et al, 2005). Vários aspectos os diferenciam, principalmente: a cinética de depleção das células $B$ e a estequiometria em que permanecem após realizarem as interações com o antígeno CD20 (Klein et al, 2013). Em 1997, foi aprovado especificamente para o tratamento de pacientes com LNH de baixo grau (folicular) ou linfomas foliculares agressivos non- Hodgkin, o primeiro anticorpo recombinante: Rituximabe (MabThera®, Rituxan) (Kotani et.al., 2006).

O MabThera ${ }^{\circledR}$ Rituxan e a maioria dos anticorpos anti-CD20 são classificados como tipo I (Figura 5), exemplos: ocrelizumab $(2 \mathrm{H} 7)$ e ofatumumab (2F2). Os anticorpos tipo I após estabelecerem as ligações com o antígeno CD20, induzem a sua translocação em microdomínios lipídicos dentro da membrana plasmática, depletando o linfócito $B$ através dos seguintes mecanismos: morte celular programada PCD (do inglês Programmed Cell Death), citotoxidade celular dependente de anticorpo ADCC (do inglês Antibody Dependent Cell Mediated Cytotoxicity), fagocitose celular dependente de anticorpo ADCP (do inglês AntibodyDependent Cellular Phagocytosis), citotoxidade dependente de complemento CDC (do inglês complement- mediated cytotoxicity), (Oflazoglu e Aldoly, 2010).

O processo de translocação do CD20 favorece geometricamente a formação de clusters de anticorpos (Figura 5) na superfície do limfócito B posicionando melhor a região $\mathrm{Fc}$ do anticorpo aumentando o recrutamento da função efetora (Marszal e Fowler, 2012). A cinética de depleção das células B promovida por imunoglobulinas anti-CD20 do tipo II (Figura 5) deve-se á adesão homotípica que eles realizam ao se ligarem na molécula CD20. Sendo assim, eles induzem menos CDC e ADCC. (Binder et. al., 2006). Recentes estudos comprovaram que os anticorpos anti-CD20 do tipo II, não promovem apoptose e sim uma forma direta e não apoptótica de morte celular. A interação de um anti-CD20 tipo II com a molécula CD20 aumenta o contato da actina célula a célula resultando no rompimento dos lisossomos e da 
geração de espécies reativas de oxigênio promovendo a morte celular. São exemplos de anticorpos tipos II: GA101 e tositumomabe (B1) (Klein et al, 2013).

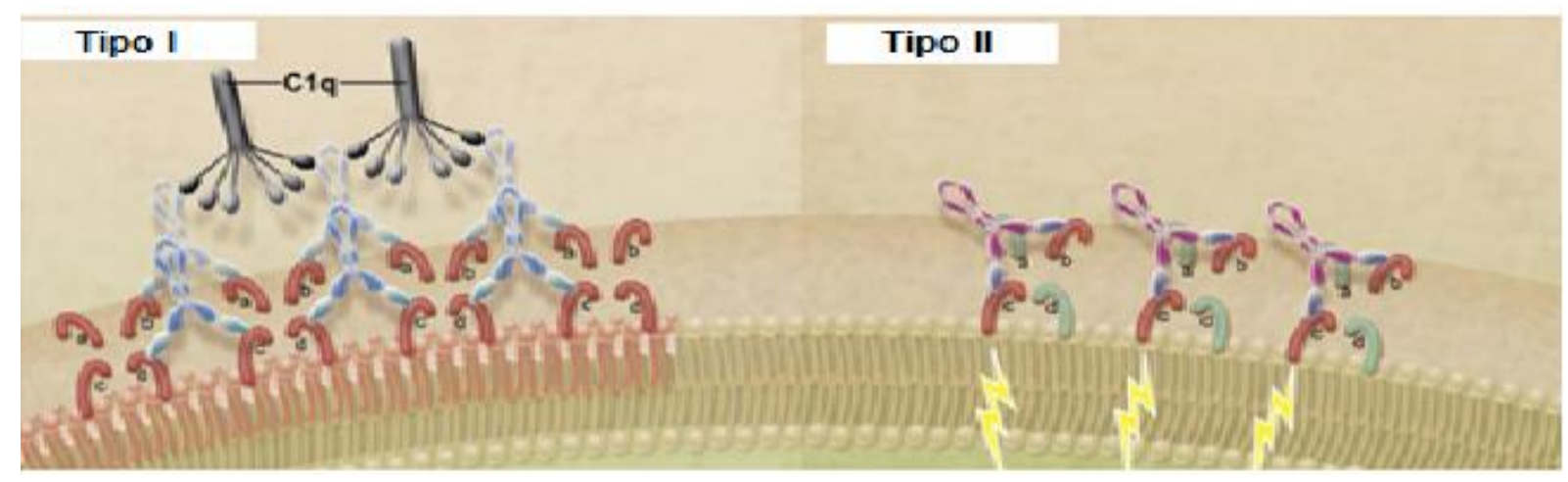

Figura 5: Demonstração esquemática da interação antígeno CD20 e os dois tipos de anticorpos anti-CD20: tipo I e tipo II respectivamente. Adaptada de (Cragg, 2011).

O rituximabe consiste em um anticorpo monoclonal quimérico anti-CD20, onde a fração $F v$ é de origem murina e fusionada às regiões humanas constantes de IgG1 e Ck, seu peso molecular é de $145 \mathrm{kDa}$ sendo duas cadeias pesadas de 451 aminoácidos e duas cadeias leves de 213 (Lim, et.al., 2010). Este modelo quimérico, no formato de IgG1 humana é atualmente, utilizado no tratamento de pacientes com Leucemia Linfocítica Crônica (LLC) (Keatting, 2010) e Artrite Reumatóide (AR) (Perscovitz, 2009) e Miastenia Graves (Wang et.al., 2014), sendo manufaturado pelas empresas Genentech e Biogen. O medicamento foi aprovado para uso clínico em 1997 (Pateinakis e Pyrpasopoulou, 2014).

$O$ antígeno leucocitário humano CD20, esta presente na superfície de células da linhagem linfóide $B$, desde seu estágio pré $B$ á linfócito $B$ maduro, não sendo, em condições naturais, expresso em plasmócitos (Oflazoglu e Aldoly, 2010). É uma fosfoproteína transmembrânica não glicosilada de aproximadamente 33 a $37 \mathrm{kDa}$ capaz de atravessar quatro vezes a membrana plasmática, estando presente na maioria dos linfócitos B. A principal característica desta molécula é uma volta ("loop") extracelular de aproximadamente 44 aminoácidos (Figura 6) com uma ponte bissulfeto entre as citeínas 167-183 localizada entre os domínios 3 e 4 transmembrânicos (Ernst et. al., 2005).

O epítopo reconhecido pelo rituximabe (Figura 6) é formado pelos peptídeos (170) ANPS (173) e (182) YCYSI (186) ambos unidos por pontes disulfeto C (167) - 
C (183) (Klein, et AL, 2013). Esses resíduos formam pontes de hidrogênio ao redor dos loops das CDRs (Klein et.al., 2013). O epítopo descontínuo do CD20 contribui com a estabilidade de ligação do rituximabe (Binder et.al., 2006). Outro fator que pode contribuir (Figura 6) são as pontes dissulfeto entre os resíduos $C(167)$ e C(183)5 que aparentemente se aproximam favorecendo a ligação do rituximabe ao epítopo descontínuo, sendo que, os resíduos de alanina na posição 170 (A170), e prolina na posição 176 (P172) são considerados os mais relevantes para permitir que estas interações sejam formadas (Klein et.al., 2013).

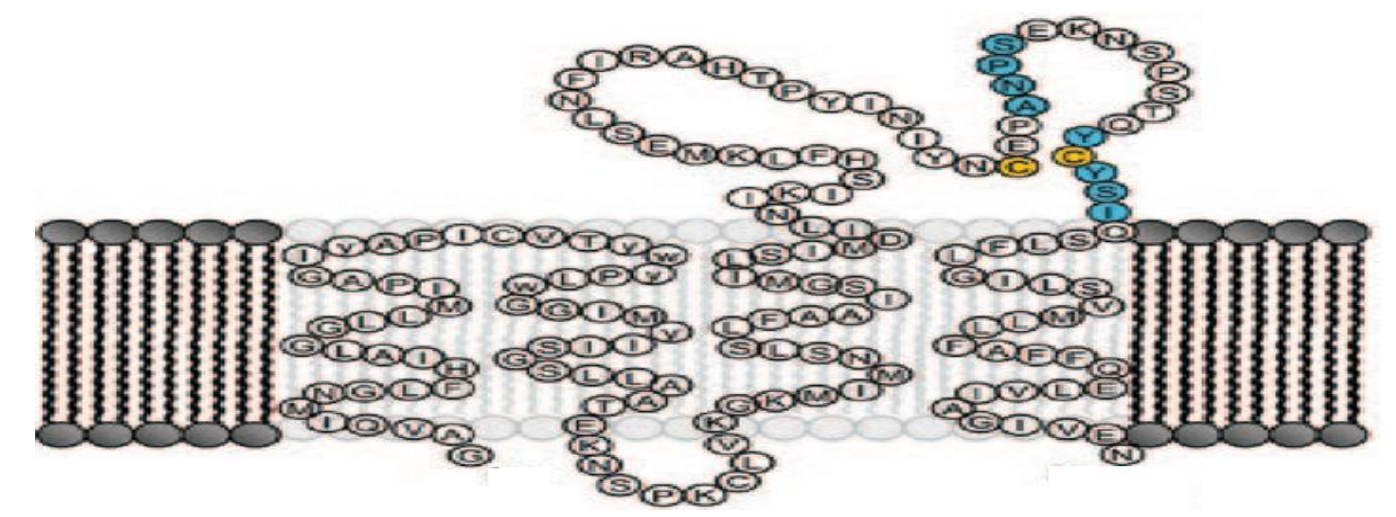

Figura 6: 0 epítopo descontínuo ao qual o rituximabe se liga. Em amarelo os resíduos $C(167)$ e $\mathrm{C}(183) 5$ que formam pontes dissulfeto. *Adaptada de (Binder et.al., 2006).

Nas células B normais, a expressão do antígeno CD20 é de aproximadamente 100.000 moléculas por células, em outros tipos celulares esta expressão é insignificante, mas nas células B malignas esta expressão encontra- se aumentada (Montraveta et.al., 2014).

Sendo assim, o rituximabe causa uma depleção seletiva e transitória de ambas subpopulações de células $B$ normais CD20 positivas e de células $B$ malignas (Figura 7). Porém, a expressão do CD20 ocorre dentro de etapas chaves do desenvolvimento das células $B$ que dão origem a diversas patologias, não sendo expresso em células-tronco hematopoiéticas $B$, de modo que a hematopoiese de células $B$, os plasmócitos e outras linhagens de células não são alvejadas (Ruuls et.al., 2008).

Dados na literatura demonstram que o espectro de ação deste biofármaco em outras patologias onde, a depleção de células B CD20+ pode ser relevante (Montraveta et.al., 2014). Já existem aplicações nos seguintes tipos de doenças: Lupus eritematoso sistêmico (Pateinakis e Pyrpasopoulou, 2014). Síndrome de Stiff 
Person (Bacorro e Tehrami, 2010), Diabetes Mellitus do tipo I (Xinyu et.al, 2013), Leucemia Linfóide Crônica (Keating, 2010), como adjuvante para a tolerização de órgãos em procedimentos de rejeição a transplantes (Sarkar e Philip, 2013) dentre outras.

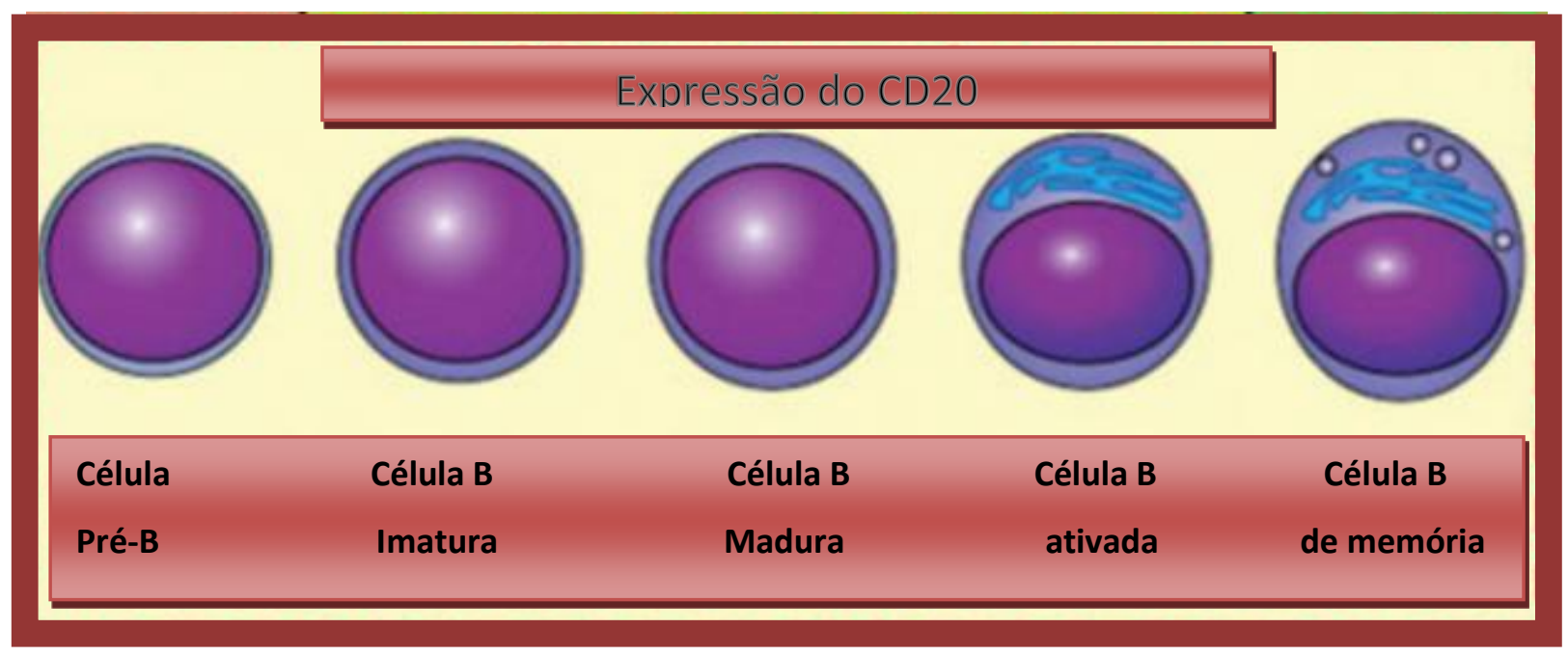

Figura 7: Linhagens de linfócitos que expressam o antígeno CD20. *Adaptada de (Ruuls et.al., 2008).

Diversos estudos demonstram que o papel terapêutico do Rituximab na depleção de células $B$ esta relacionado com quatro mecanismos (Figura 8): ADCP, CDC, ADCC e PCD (Ruuls et.al., 2008).

Vários mecanismos são descritos sobre apoptose (Figura 8) durante 0 tratamento com anti- CD20, porque após estabelecida a interação do anticorpo com o CD20 ocorrem fosforilações na membrana plasmática das células- alvo (Pateinakis e Pyrpasopoulou, 2014). As vias apoptóticas incluem tanto mecanismos intrínsecos da via de ativação da caspase quanto, vias dependentes de permeabilização. (Oflazoglu e Aldoly, 2010). São exemplos clássicos: as vias das caspases 3 e 9 , interações com os genes Bcl-2 e Bcl-6, com as vias Bax e Bak e com o NFkB (Pateinakis e Pyrpasopoulou, 2014).

Os anticorpos de classe lgG1 como o rituximabe, facilitam a deposição de proteínas do sistema complemento por meio da via clássica quando ligam-se aos seus respectivos antígenos, formando um imunocomplexo (Figura 8), resultando na citotoxidade dependente de complemento (CDC). Isso acontece porque a proteína 
C1q do complemento se liga as duas regiões $\mathrm{Fc}$ do anticorpo quimérico as quais ficam expostas (Amoroso et.al., 2011).

As células Natural Killer também reconhecem e se ligam à região cristalizável (receptor Fc) do rituximabe, mas por meio de seu receptor FcyRllla. Essas células são então ativadas, devido à ligação entre seu receptor e por meio das interações entre as porções hidrato de carbono, liberando grânulos capazes de destruir a célula B (Pievani et.al., 2011). Outro evento, menos descrito na literatura, é a fagocitose dependente de anticorpo. Macrófagos e monócitos expressam receptores Fc e receptores para proteínas do sistema do complemento, logo existe a possibilidade do linfócito ser fagocitado juntamente com o anticorpo (Pateinakis e Pyrpasopoulou, 2014).

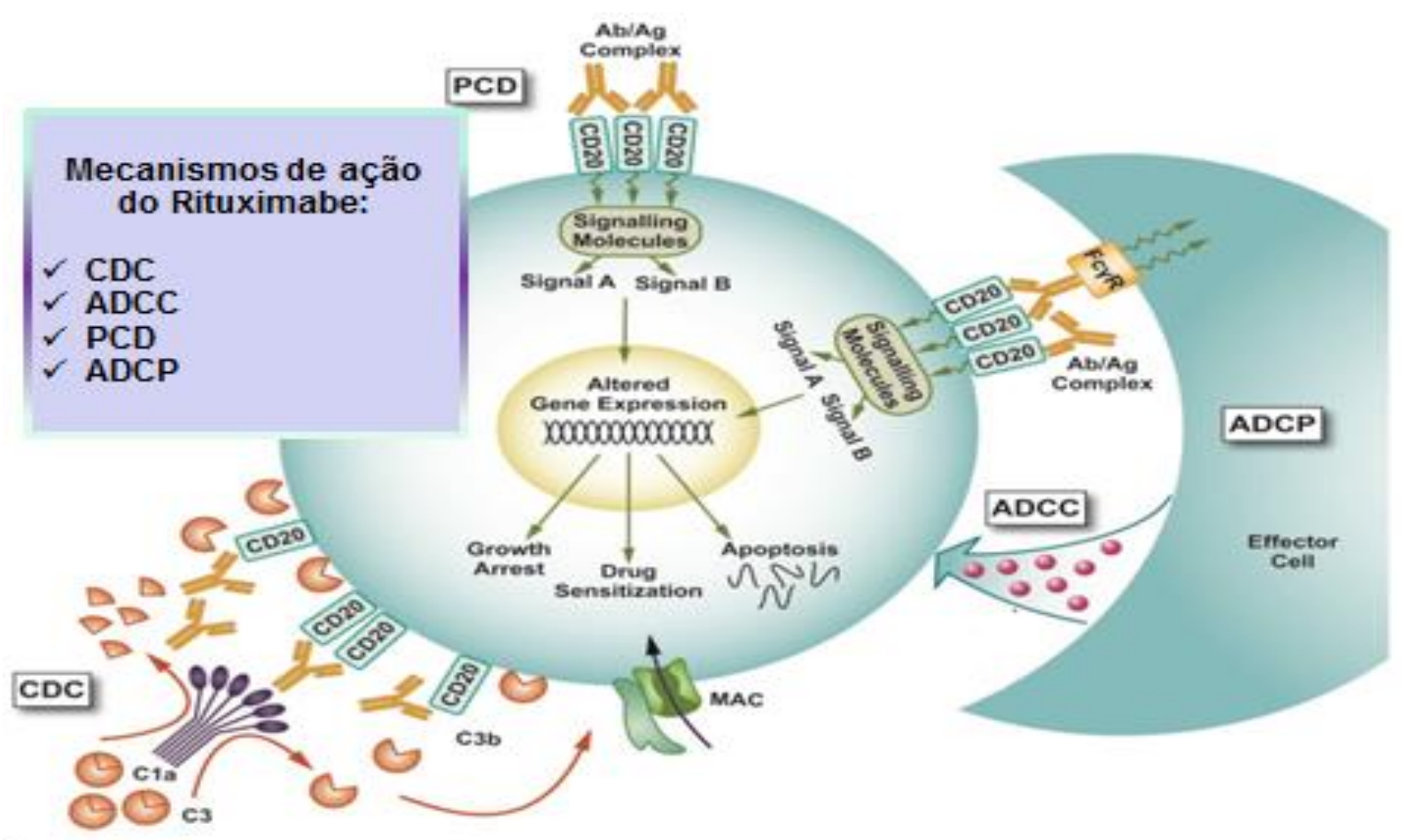

Figura 8: Mecanismos de ação propostos pelo rituximabe contra o antígeno CD20 humano. *Adaptada de (Oflazoglu e Aldoly, 2010).

Apesar do rituximabe ser eficaz em depletar células B, cerca de $50 \%$ dos pacientes com câncer HNL CD20 não respondem à terapia inicial com rituximabe, resistência inata, de 30 e cerca de $60 \%$ dos pacientes não vão mais se beneficiar com o tratamento novamente, resistência adquirida (Zimmermann et al, 2014). 
Estudos mostram que alterações no domínio intracelular do antígeno CD20 podem afetar a função das proteínas pró-apoptóticas SERCA3 e Bax/Bak resultando num decréscimo do influxo de $\mathrm{Ca}^{2+}$ intracelular inibindo a apoptose. Porém, acreditase que a maior parte dos mecanismos de resistência não estão vinculados a atividades intrínsecas das células B malignas (Zimmermann et al, 2014).

Outro mecanismo de resistência comum esta relacionado à constituição gênica dos receptores FcyR das células efetoras. Alguns genes responsáveis por codificar esses receptores exibem polimorfismo alélico, resultando em alótipos, por exemplo o geneFcyRIII: devido ao seu dimorfismo, pode codificar FcyRIIla (CD16) com o aminoácido fenilalanina $(F)$ ou valina $(V)$ na posição 158. Os indivíduos homozigotos para FcyRIIla-valina valina158 (V_/_V) estabelecem ligações mais fortes com o fragmento Fc da IgG1 (Waleed e Tim, 2011).

Entretanto, este polimorfismo e a redução da eficácia do tratamento com o rituximabe são contestáveis, por exemplo, de acordo com Zimmermann et. al 2014 , pacientes com doenças linfoproliferativas pós- transplantados portadores da região polimórfica com fenilalanina na posição 158 do FcgRllla podem responder bem ao tratamento desde que aumentadas as doses do biofármaco, imunoquimioterapia RCHOP em vez de quimioterapia CHOP (ciclofosfamida, hidroxidoxorubicina, vincristina e prednisona) após monoterapia rituximab R-CHOP (Zimmermann. et al, 2014). Outro exemplo de polimorfismo ocorre no componente C1qA do sistema complemento, e está correlacionado com a remissão completa após a terapia prolongada do rituximabe (Waleed e Tim, 2011).

Apesar da eficiência, em 3\% dos pacientes com linfoma, a terapia com rituximabe pode estar associada a imunossupressores e corticosteróides devido à respota HACA (Human Anti-Chimeric Antibodies) (van Oers e Kersten, 2011). Porém essa resposta é bem maior quando o rituximabe é usado para o tratamento de doenças auto-imunes e leva a uma tolerização à terapia (Pinto et.al., 2013). Com a finalidade de minimizar tais efeitos colaterais, foram propostos outros modelos de anticorpos recombinantes, de origem murina ou humanizados, dentre os quais destacam- se Ofatumumab 6,7, Ocrelizumab8, Veltuzumab 11,12, AME-133v13,14 e GA101 (Lim et. al., 2010). Na tabela 2 estão representados os anticorpos anti- CD20 utilizados na clínica médica e aprovados pela FD.A. 
Tabela 2: Anticorpos anti-CD20 utilizados na clínica médica e aprovados pela FDA.

\begin{tabular}{|c|c|c|c|c|c|}
\hline Anticorpo & Forma & Tipo & Indicação & Empresa & $\begin{array}{c}\text { Ano de } \\
\text { aprovação ou } \\
\text { Fase de teste }\end{array}$ \\
\hline $\begin{array}{l}\text { Rituximabe } \\
\text { Rituxan }\end{array}$ & Quimérico & $T$ & NHL, RA & Genentech & 1997 \\
\hline $\begin{array}{l}\text { Ibritumoabe } \\
\text { Zevalin }\end{array}$ & Murino & 1 & $\mathrm{NHL}$ & Biogen IDEC & 2002 \\
\hline $\begin{array}{l}\text { Tositumomabe } \\
\text { Bexxar }\end{array}$ & Murino & ॥ & $\mathrm{NHL}$ & $\begin{array}{c}\text { GlaxoSmithKlin } \\
\mathrm{e}\end{array}$ & 2003 \\
\hline $\begin{array}{c}\text { Ofatumumabe } \\
\text { Arzerra }\end{array}$ & Humano & I & NHL, RA, CLL & $\begin{array}{c}\text { Genmab, } \\
\text { GlaxoSmithKlin } \\
\mathrm{e}\end{array}$ & 2009 \\
\hline Ocrelizumabe & Humanizado & 1 & NHL, RA & $\begin{array}{l}\text { Genentech, } \\
\text { Roche, Biogen }\end{array}$ & III \\
\hline Veltuzumabe & Humanizado & 1 & NHL, ITP & Immunomedics & ॥ \\
\hline Obinutuzumabe & Humanizado & $\|$ & NHL, CLL & Roche & $\|$ \\
\hline AME-133v & Humanizado & 1 & NHL & $\begin{array}{l}\text { Applied } \\
\text { Molecular } \\
\text { Evolution }\end{array}$ & ॥ \\
\hline TRU-015 & $\mathrm{FvFc}$ & ॥ & RA & $\begin{array}{l}\text { Trubion } \\
\text { Pharma }\end{array}$ & ॥ \\
\hline PR0131921 & Humanizado & 1 & NHL, CLL & Genentech & I, II \\
\hline GA-101 & Humanizado & II & CLL, NHL & Glycart / Roche & I, II \\
\hline
\end{tabular}

*Adaptada do site da Food Drug Administration

Disponível em : http://www.antibodysociety.org/news/approved mabs.php 


\subsection{Expressão heteróloga de anticorpos em células de mamíferos}

Na década de 1970, com o aperfeiçoamento das técnicas de engenharia genética e produção de proteínas recombinantes, surgiu um grande interesse por parte dos pesquisadores em padronizar técnicas e protocolos para produção de biofármacos em células de mamíferos. Essas células perfazem o sistema ideal para produção de anticorpos. Elas possuem capacidades intrínsecas de mimetizar essa produção pelo organismo humano, devido ao alto grau de fidelidade em relação às modificações pós-traducionais, tais como: a N-gligosilação, acetilação, metilação, fosforilação, glicosilação, prenilação, sulfonação dentre outros (Jayapal et.al., 2007).

Segundo Datta et.al., 2013, a produção industrial de anticorpos recombinantes por meio de células de mamíferos, em especial as células $\mathrm{CHO}$, correspondem a mais de $70 \%$ das proteínas terapêuticas em um mercado global avaliado em US $\$ 30$ bilhões em vendas anuais (Datta et. al., 2013).

A linhagem imortalizada de ovário de hamster chinês $(\mathrm{CHO})$ e suas variantes, como por exemplo a $\mathrm{CHO}-\mathrm{K} 1$, são comumente utilizadas para produção de biofármacos (Ruggiero, 2002). Essas células epiteliais de morfologia fibroblastóide são aderentes ao plástico. Para permanecerem aderidas ao plástico após se propagarem, ou mesmo manterem sua morfologia, essas linhagens de $\mathrm{CHO}$ necessitam de soro fetal bovino como fonte de hormônios, fatores de crescimento, proteção contra variações de pH e pressão osmótica (Jayapal et.al., 2007).

Para que as células de mamíferos possam produzir anticorpos fidedignos a sua sequência gênica, elas necessitam de vetores de expressão adaptados as suas necessidades, e previamente planejados a lidar com alguns dos mecanismos de regulação da expressão gênica em eucariotos (Silva et. al., 2009). O Grupo de Imunologia Molecular da UnB, trabalha com diversos projetos na área de expressão heteróloga de anticorpos, vários vetores foram construídos com o objetivo de melhorar a produção dessas proteínas recombinantes. O vetor utilizado neste trabalho, foi o vetor pCOMIRES $\Delta 600$. (Figura 9) (Quilici, 2012). 


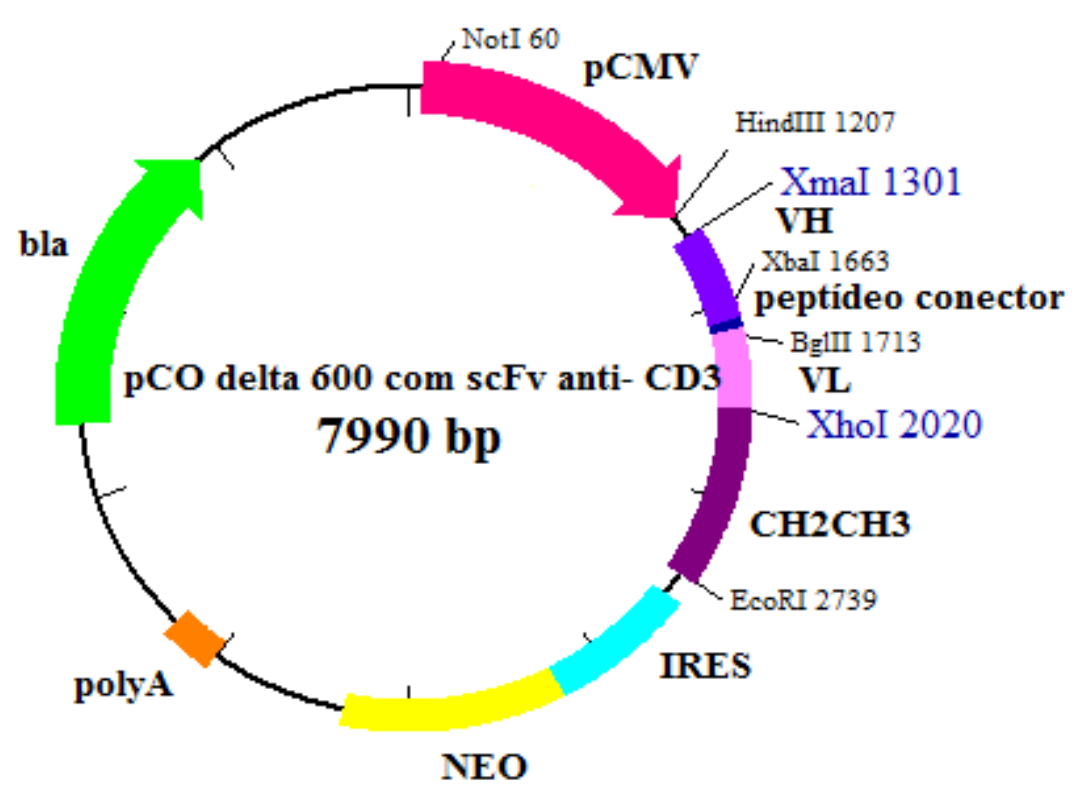

Figura 9: Desenho esquemático do vetor pCOMIRES $\Delta 600$. Adaptado de (Qulici, 2012).

O vetor foi construído por Quilici (2012) e possibilita a produção heteróloga das proteínas recombinantes em células de mamíferos. $O$ vetor pCOMIRES $\triangle 600$ possui os genes relacionados com as cadeias $\mathrm{CH} 2$ e $\mathrm{CH} 3$ do $\mathrm{Fc}$ de imunoglobulina humana IgG, que estão presentes entre o sítio da enzima Xho I e da enzima EcoR I, de forma que a proteína liberada pela célula de mamífero corresponda ao fragmento FvFc do anticorpo (Quilici, 2012). O vetor pCOMIRES $\triangle 600$, também possui: gene para resistência á ampicilina (Bla), que facilita a manipulação em bactéria e o gene de resistência a geneticina $\left(\mathrm{NEO}^{\mathrm{R}}\right)$, para a seleção de transfectomas estáveis (Sousa, 2013).

Os genes que codificam o fragmento FvFc estão em fase com a sequência líder, codificadora do peptídeo sinal de imunoglobulina, dirigindo assim os produtos recombinantes para o aparato secretório da célula (Sousa, 2013). A expressão do gene é dirigida pelo promotor CMV (Citomegalovírus), este promotor tem como principal característica promover altos níveis de transcrição do gene da proteína recombinante (Mariati et.al., 2010), para tanto ele possui o íntron A com uma deleção de 600 pares de base (Quilici, 2012). O íntron A é responsável para que a performance do processo de splicing ocorra de forma a permitir maior fidelidade de transcrição do $\mathrm{FvFc}$, que encontra-se clonado como cDNA (Le et.al., 2003). O vetor também possui o sinal de poliadenilação eficiente do vírus 40 de macaco SV40 
(Smian Vírus 40) que codifica a "cauda polyA" do RNA (Le et.al., 2003).

Outra característica importante é que o gene de resistência a geneticina $\left(\mathrm{NEO}^{\mathrm{R}}\right.$ ) está clonado a montante á um elemento IRES (do inglês Internal Ribossome Entry Site). O IRES consiste em sequências localizadas na região 5 'UTR (do inglês Untranslated Region) de alguns vírus de RNA e sua presença em um vetor de expressão é considerada extremamente importante para possibilitar a expressão policistrônica por permitir uma expressão duradoura e estável de proteínas recombinantes, como imunoglogulinas (Houbebine et.al., 1999).

Essa característica faz com que tanto o mRNA gerado a partir do cassete de expressão contenha a sequência codificadora da proteína recombinante, o IRES e a sequência que codifica a marca seletiva Neo. Esse mRNA serve de molde para a tradução simultânea de ambos os cistrons, de forma que ao se selecionar a célula pela sua resistência a geneticina, seleciona-se aquele com capacidade de produzir proteína recombinante (Houbebine et.al., 1999).

Um vetor com todas essas características pode influênciar positivamente no processo de produção de anticorpos recombinantes, e ser uma estratégia promissora para produção em larga escala.

\subsection{Desenho gênico de versões humanizadas dos domínios variáveis leve e pesado do rituximabe.}

Com o objetivo de desenvolver uma estrutura menos complexa do que a do anticorpo inteiro, podendo apresentar um tempo de meia vida menor na circulação sanguínea, sendo considerado ideal nos tratamentos onde a rápida remoção do biofármaco pode resultar em uma melhor evolução do quadro do paciente (Maranhão e Brígido, 2002), foram produzidos dois fragmentos FvFc humanizados e um fragmento FvFc similar a estrutura original do rituximab, onde o domínio Fc é o mesmo que o dos domínios da lgG humana.

A especificidade da molécula original foi mantida, transplantando as CDRs murinas do rituximabe para dois arcabouços humanos, através da técnica CDR grafting. Não foi necessário realizar a construção da molécula inteira, uma vez que o grupo de Imunologia Molecular já tinha uma sequencia gênica para dos domínios $\mathrm{CH} 2$ e $\mathrm{CH} 3$, clonados no vetor de expressão pCOMIRES $\Delta 600$. Os scFvs foram 
desenhados de forma a propiciar a fusão gênica desses domínios e receber as CDRs murinas do rituximabe, analisando os resíduos de aminoácidos essenciais correspondentes a sequencia que codifica a estrutura cristalográfica.

Como visto, manter as CDRs murinas do rituximabe é uma estratégia promissora, pois o êxito na depleção das células B em uma fase de desenvolvimento chave promove um tratamento adequado à pacientes de várias patologias. As CDRs são capazes de manter esta identidade da molécula progenitora. Possíveis mutações que possam ocorrer na molécula CD20 afetando o epítopo do rituximabe são raras, ocorrem em apenas 0,4\% dos pacientes. (Klein et. al., 2013).

Foram selecionados frameworks humanos para as cadeias VH e VL murinas que estão presentes no anticorpo original Rituximabe (Andrade et.al., 2000). E realizadas buscas a partir de sequências humanas de cadeias variáveis germinais depositadas no banco de dados que apresentaram maior similaridade com a sequência do anticorpo murino (Caldas, 2000). Essas sequências foram alinhadas e analisadas usando o programa Bioedit. Para a escolha das sequências similares, foi considerada as sequencias depositadas no lg Blast.

Segundo Kaswiuri et. al 2005, a correta escolha de um modelo tridimensional humano e a identificação dos resíduos no framework, são cruciais para estabelecer ligações com o antígeno (Kaswiuri et. al 2005). O uso das sequencias germinais reduz a imunogenicidade da molécula. Os frameworks de dois anticorpos humanos diferentes podem ser usados como molde para o processo de humanização das cadeias VH e VL, no caso desta humanização as duas versões humanizadas são similares em relação a estrutura tridimensional, pois as duas cadeias $L$ poderiam receber as CDRs do rituximab e a mesma cadeia $\mathrm{H}$ de imunoglobulina, logo foram produzidos dois fragmentos ScFv humanizados com a mesma cadeia pesada e diferentes cadeias leves.

Posteriormente, foram realizadas a retro-tradução das sequências peptídicas em polinucleotídicas, levando em conta a presença de códons preferenciais para células de mamíferos, propondo- se a sequência dos genes a serem sintetizados quimicamente (Caldas et. al, 2000). Foram selecionados dois segmentos germinais de cadeias pesadas de imunoglobulina e três seguimentos germinais para cadeia

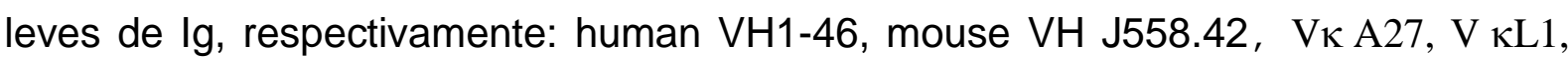
$\mathrm{V} \kappa \mathrm{am} 4$. Sendo assim, foram sintetizadas quimicamente duas versões scFvs 
humanizadas e uma versão $\mathrm{ScFv}$ murina similar a do rituximabe original,

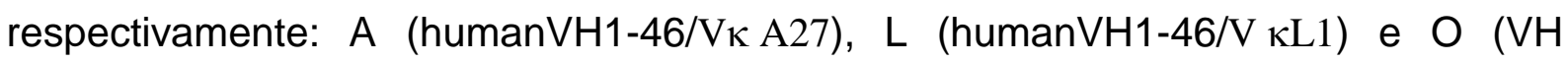
J558.4/Vкат4). 
Objetivos 


\subsection{Objetivo Geral}

Expressar, produzir e purificar, fragmentos de anticorpos anti-CD20 na forma FvFc. Sendo, uma versão FvFc murina similar ao rituximabe original e duas versões FvFcs humanizadas.

\subsection{Objetivos Específicos}

- Clonagem dos scFvs humanizados e murino no vetor de expressão pCOMIRES $\triangle 600$.

- Obtenção da população mista de células CHO-K1 produtoras dos FvFcs recombinantes.

- Produção e purificação das proteínas recombinantes. 
Materiais e Métodos 


\subsection{Materiais}

\subsubsection{Linhagem de bactéria}

Linhagem de bactéria Escherichia coli utilizada para os procedimentos de clonagem neste trabalho, os genes listados indicam alelos mutantes.

- XL1-blue (Stratagene): recA1 endA1 gyrA96 thi-1 hsdR17 supE44 relA1 lac [F'proAB laclqZ $\Delta \mathrm{M} 15$ Tn10 (Tetr)]. E. coli foi desenvolvida para a transformação de grandes moléculas de DNA, e com alta eficiência.

\subsubsection{Linhagem de Célula de Mamífero}

- CHO-K1- Linhagem celular derivada da subclonagem de uma célula de ovário de hamster Chinês $(\mathrm{CHO})$ parental, iniciada pela biópsia de um ovário da fêmea adulta do hamster Chinês Cricetulus griseus.

São células epiteliais, aderentes e necessitam de suplementação de soro fetal bovino e prolina ao meio de cultura. Número ATCC: CCL-61. As células foram cultivadas em meio HAM-F12 (Hyclone) contendo soro fetal bovino (SFB) a uma concentração de $10 \%(\mathrm{v} / \mathrm{v})$

\subsubsection{Meios de Cultura e soluções para bactérias}

Meio LB (Luria-Bertani)

Peptona de caseína 1,0 \% (p/v)

Extrato de levedura $0,5 \%(\mathrm{p} / \mathrm{v})$

$\mathrm{NaCl} 1,0 \%(\mathrm{p} / \mathrm{v})$

$\mathrm{pH} 7,0$.

Meio LB ágar

Meio LB adicionado de ágar bacteriológico a 1,4% (p/v).

Meio SB (Super Broth)

Peptona de caseína 3,0 \% (p/v) 
Extrato de levedura 2,0\% (p/v)

MOPS $1,0 \%(p / v)$

$\mathrm{pH} 7,0$.

Meio SOB

Bacto-triptona 2,0\% (p/v)

Extrato de levedura $0,5 \%(\mathrm{p} / \mathrm{v})$

$\mathrm{NaCl} 0,06 \%(p / v)$

$\mathrm{KCl} 0,002 \%(p / v)$

$\mathrm{pH} 7,0$.

Meio SOC

Meio SOB $98 \mathrm{~mL}$

Solução estoque de $\mathrm{Mg}^{2+} 2 \mathrm{M} 1 \mathrm{~mL}$

Solução estoque de glicose $2 \mathrm{M} 1 \mathrm{~mL}$

Solução estoque de glicose $2 \mathrm{M}$

Esterilizada por filtração e estocada a $4^{\circ} \mathrm{C}$.

Solução estoque de Mg $2 \mathrm{M}$

$\mathrm{MgCl}_{2} 1 \mathrm{M}$

$\mathrm{MgSO}_{4} 1 \mathrm{M}$

Esterilizada por filtração e estocada a $4^{\circ} \mathrm{C}$.

Solução de $\mathrm{CaCl}_{2}$

$\mathrm{CaCl}_{2} 50 \mathrm{mM}$

Esterilizada por filtração e estocada a $4^{\circ} \mathrm{C}$

Glicerol $50 \%(\mathrm{v} / \mathrm{v})$

Esterilizado por filtração e estocada a $4^{\circ} \mathrm{C}$ 
Cubetas de eletroporação (Gene Pulser/MicroPulser Cuvettes, Biorad ${ }^{\circledR}, n^{0}$ catálogo: 165-2086)

Após dissolver os reagentes em água, todos os meios de cultura foram autoclavados a $120^{\circ} \mathrm{C}$ por 15 minutos

\subsubsection{Meios de cultura e soluções para cultura de células de mamíferos}

Para a cultura das linhagens de células de mamífero utilizadas neste estudo, foi utilizado o meio de cultura HAM-F12 da Sigma e da Gibico. Todos esses meios de cultura apresentam uma composição química bastante complexa, contendo sais inorgânicos diversos, vitaminas, aminoácidos e outros compostos. Era adicionado bicarbonato de sódio no meio, com a finalidade de manter o pH durante a estocagem a $4 \mathrm{C}^{\circ}$.

Meio Ham-F12 com L-Glutamina a 2 mM (Invitrogen $\circledast$, no cat 21700-075)

Meio Base 1 pacote

$\mathrm{NaHCO}_{3} 1,176 \mathrm{~g}$

$\mathrm{dH}_{2} \mathrm{O}$ q.s.p $1 \mathrm{~L}$

$\mathrm{pH} 7,4$

Meio de Congelamento de Células

HamF12 45\%

Soro Fetal Bovino $45 \%(\mathrm{v} / \mathrm{v})$

DMSO $10 \%(v / v)$

Soluções utilizadas para cultura de células $\mathrm{CHO}-\mathrm{K} 1$ :

*Tripsina-EDTA (Invitrogen ${ }^{\circledR}, \mathrm{n}^{\circ}$ catálogo: 27250-018)

Tripsina $2,5 \mathrm{~g}$

EDTA $0,38 \mathrm{~g}$

BSS.CMF qsp $1 \mathrm{~L}$

$\mathrm{pH} 8,0$ 
*Soro Fetal Bovino (Invitrogen ${ }^{\circledR}, \mathrm{n}^{\circ}$ catálogo: 10438-026)

Estocar de -5 a $-20{ }^{\circ} \mathrm{C}$.

Adicionado ao meio de cultura Ham-F12 com L-glutamina à concentração de $5 \%$ ou $10 \%(\mathrm{v} / \mathrm{v})$.

${ }^{*}$ Azul de Tripan

Corante Azul de Tripan $400 \mathrm{mg}$

PBS pH 7,2 q.s.p. $100 \mathrm{~mL}$

*Reagente de transfecção JetPEI ${ }^{\mathrm{TM}}$ (Polyplus Transfection, $n^{\circ}$ de catálogo 101-01N)

Esse reagente de transfecção é um derivativo linear de uma polietilenimina. É um composto catiônico cuja formulação específica permite a transfecção de diversas linhagens de células de mamíferos.

\subsubsection{Soluções para extração de DNA plasmidial}

Solução I

Tris- $\mathrm{HCl} \mathrm{pH} 8,025 \mathrm{mM}$

EDTA pH 8,0 10 mM

Glicose $50 \mathrm{mM}$

Solução II

$\mathrm{NaOH} 0,2 \mathrm{M}$

SDS $1,0 \%(p / v)$

Solução III

Acetato de potássio $3 \mathrm{M}$

Ácido Acético $2 \mathrm{M}$

pH ajustado para 4,8 - 5,0

RNAse A (Invitrogen ${ }^{\circledR}, \mathrm{n}^{\circ}$ de catálogo 12091-021). 


\section{Clorofane}

Fenol equilibrado em $\mathrm{pH}$ 7,6 $1 \mathrm{v}$

Clorofórmio $1 \mathrm{v}$

B-hidroxiquinilona $0,05 \%(p / v)$

Equilibrado com 0,1 v de Tris-HCl $100 \mathrm{mM} \mathrm{pH} \mathrm{7,6}$

Clorofil

Clorofórmio $24 \mathrm{v}$

Álcool isoamílico $1 \mathrm{v}$

Equilibrado com $0,25 \vee$ de tampão TE

Acetato de Sódio 3 M, pH 4,8

Utilizada para precipitação de DNA em preparação de pequena escala.

Acetato de amônio 7,5 M

Utilizada para precipitação de DNA em preparação de larga escala.

\subsubsection{Enzimas}

\section{Enzimas de Restrição}

*Biolabs:

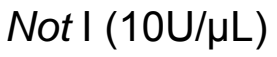

Hind III $(10 \mathrm{U} / \mu \mathrm{L})$

EcoR I $(20 \mathrm{U} / \mu \mathrm{L})$

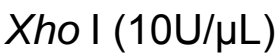

$X m a$ I $(1 \mathrm{U} / \mu \mathrm{L})$

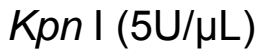

Pst I $(10 \mathrm{U} / \mu \mathrm{L})$

*Fermentas:

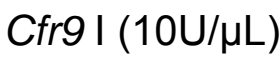

Xho I (10U/uL) 
*Promega

Kpn I (10U/ $/ \mathrm{L})$

$P s t \mathrm{I}(10 \mathrm{U} / \mu \mathrm{L})$

Outras enzimas

*Invitrogen

T4 DNA Ligase (100u/ uL)

Taq DNA polimerase (100 u/uL) Invitrogen

\subsubsection{Soluções e reagentes para eletroforese em gel de agarose}

Tampão de corrida TEB 1X (Trizma- Base, Edta, Ácido Bórico) pH 8,0

Tampão de corrida TAE 1X (Trizima- Base, Tris- Acetato, Ácido Ácetico Glacial)

Tampão de amostra para gel de agarose 10X Azul de Bromofenol 0,1 \% (p/v)

\subsubsection{Anticorpos utilizados no ELISA}

Goat anti-Human IgG $(\mathrm{H}+\mathrm{L})$ Secondary Antibody $2 \mathrm{mg}$, da Life thecnologies, número de catálogo A18807.

F(ab')2-Goat anti-Human IgG Fc Secondary Antibody, AP conjugate 500ug, da Life thecnologies, número de catálogo A24479. (Também utilizado no Western). 


\subsubsection{Oligonucleotídeos utilizados para confirmação das clonagens dos scFvs no vetor de expressão pCOMIRES $\Delta 600$.}

Os oligonucleotídeos foram fornecidos pela GenOne e solubilizados em água Milli-Q para concentração de uso de 10 pmoles/ $\mu \mathrm{L}$. A tabela 3 mostra as seqüências de cada um dos oligonucleotídeos.

Tabela 3. Seqüências dos oligonucleotídeos utilizados

\begin{tabular}{l|l|l}
\hline Identificação & Seqüência do Oligonucleotídeo & Utilização \\
\hline VH Xma I & 5' GGTGTACATTGTGAGCTCGCCCG 3' & $\begin{array}{l}\text { Anela com o início da CDR 1 na } \\
\text { região variável da cadeia pesada } \\
(\text { VH) }\end{array}$ \\
\hline VH Xbal & 5' TGGAACCACCGTGACCGTGT 3' & $\begin{array}{l}\text { Anela com o final da CDR 3 na } \\
\text { região variável da cadeia pesada } \\
(\mathrm{VH})\end{array}$ \\
\hline VL Bgl II & 5'CTGGAGGAGGAGGATCAGATC 3' & $\begin{array}{l}\text { Anela com o início da CDR 1 na } \\
\text { região variável da cadeia leve (VL) }\end{array}$ \\
\hline VL Xho I & 5' CCTCCTACCTTCGGAGGAGGA 3' & $\begin{array}{l}\text { Anela com o final da CDR 3 na } \\
\text { região variável da cadeia leve (VL) }\end{array}$ \\
\hline
\end{tabular}




\subsubsection{Antibióticos}

\section{Ampicilina}

A ampicilina liofilizada foi ressuspendida em água destilada na concentração de 20 a $50 \mathrm{mg} / \mathrm{mL}$. Após a ressuspensão, ela foi esterilizada por filtração em membrana Millipore de $0,22 \mu \mathrm{m}$. Após a filtração, ela foi estocada a $-20^{\circ} \mathrm{C} \mathrm{e}$ protegida da luz. Este antibiótico foi utilizado como marca de seleção para plasmídios transformados em células de E. coli.

\section{Tetraciclina}

A tetraciclina liofilizada foi ressuspendida em etanol $70 \%$ na concentração de $50 \mathrm{mg} / \mathrm{mL}$ e esterilizada por filtração em membrana Millipore de 0,22 $\mu \mathrm{m}$. Após a filtração, ela foi estocada a $-20^{\circ} \mathrm{C}$ e protegida da luz. Este antibiótico foi utilizado para a semeadura e manutenção de células $E$. coli das linhagens XL1-blue e XL10gold, que possuem o gene de resistência a esse antibiótico.

\section{Antibiótico/Antimicótico 100X (GIBCO)}

Penicilina 10.000U

Estreptomicina $10.000 \mu \mathrm{g}$

Anfotericina B $25 \mu \mathrm{g} / \mathrm{mL}$

Preparada em $0,85 \%$ de salina

Solução utilizada como antibacteriano e antimicótico que foi adicionada aos meios de cultura das células de mamífero, na concentração final 1X.

\section{Geneticina $^{\circledR}$ (G418-Sulfato)}

Liofilizada foi ressuspendida em água destilada na concentração de $50 \mathrm{mg} / \mathrm{mL}$ e esterilizada por filtração em membrana Millipore de 0,22 $\mu \mathrm{m}$. Após a filtração, ela foi estocada a $-20^{\circ} \mathrm{C}$ e protegida da luz. A geneticina foi utilizada para a obtenção de clones estáveis de construções com seqüências indutoras de Z-DNA na linhagem CHO-K1. 


\subsubsection{Marcadores moleculares para DNA}

$1 \mathrm{~kb}$ plus DNA Ladder - (Invitrogen ${ }^{\circledR} \mathrm{n}$ ㅇ. catálogo. 10787-026)

Fragmentos de DNA em pb: 100; 200; 300; 400; 500; 650; 850; 1.000; 1.650; 2.000; $3.000 ; 4.000 ; 5.000 ; 6.000 ; 7.000 ; 8.000 ; 9.000 ; 10.000 ; 11.000 ; 12.000$.

1 kb DNA Ladder - (Invitrogen ${ }^{\circledR}$ no . catálogo. 15615-016)

Fragmentos de DNA em pb: 201; 220; 298; 344; 396; 500; 517; 1.018; 1.636; 2.036 ; $3.054 ; 4.072 ; 5.090 ; 6.106 ; 7.126 ; 8.144 ; 9.162 ; 10.180 ; 11.198 ; 12.216$.

Low Mass DNA Ladder (Invitrogen ${ }^{\circledR} \mathrm{n}$ ㅇ. catálogo. 10068-013)

Mistura equimolar de fragmentos de DNA em pb de 2.000; 1.200; 800; 400; $200 \mathrm{e}$ 100. Utilizando $4 \mu \mathrm{L}$ do marcador, corresponde a massa de 200; 120; 80; 60; 40 e 20 ng, respectivamente.

High Mass DNA Ladder (Invitrogen ${ }^{\circledR} \mathrm{n}$ ‥ catálogo 10496-016) Mistura equimolar de fragmentos de DNA em pb de 10.000; 6.000; 4.000; 3.000; 2.000 e 1.000. Utilizando $4 \mu \mathrm{L}$ do marcador, corresponde a massa de 200; 120; 80; $60 ; 40$ e 20 ng, respectivamente.

\subsubsection{Marcadores moleculares para proteína}

BenchMark Pre-Stained Protein Ladder ( 2x 250uL), Life Thecnologies, número de catálogo 10748-010.

NexusPointer Mid Range Dual Color (250ul), Bionexus, número de catálogo BNPM30.

\subsubsection{Kits comerciais}

QIAGEN Plasmid Midi Kit 100 - Para preparação plasmidial em escala intermediária (Qiagen ${ }^{\circledR}$, no. catálogo 12145).

QIAprep Spin Miniprep Kit (250) - Para preparação plasmidial em pequena escala (Qiagen ${ }^{\circledR}$, no. catálogo 27106).

Colunas para extração de DNA de gel de agarose por Freeze Squize - Ultrafree DA 
Centrifugal Unit (Millipore ${ }^{\circledR}$, no. catálogo 42600). Para extração de DNA de gel de agarose.

Qubit Fluorometer - para quantificação de DNA/RNA. Invitrogen $\left(\mathrm{n}^{\circ}\right.$ catálogo: Q32860) 


\subsection{Métodos}

\subsubsection{Preparação de DNA plasmidial}

$\checkmark$ Em pequena escala adaptado do livro Técnicas Básicas de Biologia Molecular. Capitulo IV (Maranhão e Moraes, 2003).

Para as preparações de DNA plasmídial em pequena escala, preparava- se um inóculo de 5,0 mL meio LB/ Amp ampicilina $(150 \mu \mathrm{g} / \mathrm{mL})$ com células E. coli $X L 1 B L U E$, transformadas com o plasmídio de interesse. Imcubava-se o inóculo durante 16 horas a $37^{\circ} \mathrm{C}$, sob agitação de $250 \mathrm{rpm}$.

Após o crescimento, os $3 \mathrm{~mL}$ do inóculo eram centrifugados por meio de duas centrifugações de 3 minutos a $3.000 \mathrm{rpm}$ em microtubos de $1,5 \mathrm{~mL}$, sendo o sobrenadante desprezado a cada centrifugação:

- Ressuspendia- se o sedimento em $200 \mu \mathrm{L}$ de Solução I. Depois incubava- se as amostras no gelo por 5 min.

- Após 5 min com a solução I, adicionava- se $400 \mu \mathrm{L}$ de Solução II e homogeneiza- se as amostras vagarosamente várias vezes. Incubava-se no gelo por 5 min.

- Depois, acrescentava- se $300 \mu \mathrm{L}$ de Solução III, repetindo-se o mesmo procedimento de homogeneização e incubou-se no gelo por $10 \mathrm{~min}$.

- Centrifugou-se a $12.000 \mathrm{rpm}$ por $15 \mathrm{~min}$ a $4^{\circ} \mathrm{C}$.

- Recolhia- se o sobrenadante em microtubos e eram adicionados $10 \mu \mathrm{L}$ de RNAse A (na concentração de $10 \mathrm{mg} / \mathrm{mL}$ ) depois incubava-se por 2 horas a $37^{\circ} \mathrm{C}$.

- Foram adicionados $300 \mu \mathrm{L}$ de clorofane e, após forte agitação no vortex, centrifugava-se por $5 \mathrm{~min}$ a $5.000 \mathrm{~g}$ à temperatura ambiente, e recolhiase a fase aquosa em outro microtubo.

- Foram adicionados $300 \mu \mathrm{L}$ de clorofil e repetiu-se o mesmo procedimento anterior de agitação intensa, centrifugação e coleta.

- Foram adicionados 2,0 v de etanol absoluto gelado e incubou-se a $-20^{\circ} \mathrm{C}$ por no mínimo 2 horas. 
- 10- Centrifugou-se a $12.000 \mathrm{rpm}$ por $45 \mathrm{~min}$ a $4^{\circ} \mathrm{C}$. Desprezava-se o sobrenadante.

- Foram adicionados $300 \mu \mathrm{L}$ de etanol $70 \%$ gelado e centrifugou-se novamente a $12.000 \mathrm{rpm}$ por $15 \mathrm{~min}$ a $4^{\circ} \mathrm{C}$.

- Secava-se o sedimento a vácuo ou por simples exposição ao ar.

- O sedimento foi ressuspendido em $50 \mu \mathrm{L}$ de TE, e as amostras conservadas a $-20^{\circ} \mathrm{C}$.

$\checkmark$ Em larga escala adaptado do livro Técnicas Básicas de Biologia Molecular. Capitulo IV, (Maranhão e Moraes, 2003).

Para as preparações de DNA plasmidial em larga escala, preparava- se um inóculo de $5,0 \mathrm{~mL}$ meio LB/Amp ampicilina $(150 \mu \mathrm{g} / \mathrm{mL})$ com células $E$. coli $X L 1 B L U E$, transformadas com o plasmídio de interesse. Imcubava- se o pré- inóculo durante 16 horas a $37^{\circ} \mathrm{C}$, sob agitação de $250 \mathrm{rpm}$.

Depois, eram utilizados $1 \mathrm{~mL}$ deste pré- inóculo para preparar um inóculo de $200 \mathrm{~mL}$ de cultura em meio LB/ Amp $(200 \mu \mathrm{g} / \mathrm{mL})$. A cultura crescia durante a noite por 16 horas a $37^{\circ} \mathrm{C}$, sob agitação de $250 \mathrm{rpm}$.

Posteriormente os $200 \mathrm{~mL}$ eram centrifugados durante $15 \mathrm{~min}$ a $3.000 \mathrm{xg}$, desprezando-se o sobrenadante:

- O sedimento de células era ressuspendido em $5 \mathrm{~mL}$ de Solução I sob forte agitação. Incubavam-se as amostras no gelo por $10 \mathrm{~min}$.

- Em seguida adicionava- se $10 \mathrm{~mL}$ de Solução II e homogeneizavam-se as amostras, vagarosamente diversas vezes. Depois incubavam- se as amostras no gelo por $5 \mathrm{~min}$.

- Foram adicionados $7,5 \mathrm{~mL}$ de Solução III, repetindo o mesmo procedimento de homogeneização e incubou-se no gelo por 20 min.

- Foram centrifugadas a $10.000 \times \mathrm{g}$ por $30 \mathrm{~min}$ a $4^{\circ} \mathrm{C}$.

- O sobrenadante era filtrado em papel de filtro umedecido e, eram adicionados $0,6 \mathrm{v}$ de isopropanol. Após uma incubação de 5 min à temperatura ambiente, as amostras eram centrifugadas a $12.000 \times \mathrm{g}$ por $20 \mathrm{~min}$ a temperatura ambiente. 
- Desprezou-se o sobrenadante e, após a secagem por exposição ao ar, o sedimento foi ressuspendido em $500 \mu \mathrm{L}$ de TE ao qual eram adicionados 10 $\mu \mathrm{L}$ de RNAse A. Incubou-se por 2 horas a $37^{\circ} \mathrm{C}$.

- Foram adicionados $1 \mathrm{v}$ de clorofane e, após forte homogeneização e centrifugação de 5 min a $5.000 \times \mathrm{g}$ à temperatura ambiente, a fase aquosa foi coletada para outro tubo.

- O passo anterior foi repetido mais uma vez.

- Foram adicionados $1 \mathrm{v}$ de clorofil e repetia-se o mesmo procedimento anterior de homogeneização, centrifugação e coleta.

- Adicionaram-se 0,5 v de acetato de amônio 7,5 M e 2,0 v de etanol $100 \%$ gelado seguido de incubação por, no mínimo 2 horas a $-20^{\circ} \mathrm{C}$.

- Foram centrifugadas a $12.000 \mathrm{rpm}$ por $45 \mathrm{~min}$ a $4^{\circ} \mathrm{C}$. Desprezou-se 0 sobrenadante.

- Foram adicionados $1 \mathrm{~mL}$ de etanol $70 \%$ gelado e centrifugava-se novamente a $12.000 \mathrm{rpm}$ por $15 \mathrm{~min}$ a $4^{\circ} \mathrm{C}$.

- Após secagem o sedimento foi ressuspendido em $200 \mu \mathrm{L}$ de TE, e as amostras foram conservadas a $-20^{\circ} \mathrm{C}$.

\subsubsection{Análise de DNA plasmidial por eletroforese em gel de agarose.}

Adaptado do livro Técnicas Básicas de Biologia Molecular. Capitulo VII (de-Souza, 2003).

O gel de agarose era preparado de acordo com a faixa de tamanho (kb) de DNA (dupla fita ou linear), em geral neste trabalho os géis eram feitos em 0,7 a 1,5 $\%$. O tampão utilizado era o TEB $1 \mathrm{X}$ ou TAE $1 \mathrm{X}$ com $0,5 \mu \mathrm{g} / \mathrm{mL}$ de brometo de etídeo.

Era acrescentado tampão nas amostras de DNA e depois, eram aplicadas no gel e submetidas à eletroforese em tampão TEB ou TAE 1X. Para visualização do DNA incidia-se luz ultravioleta no gel utilizando-se um transluminador (Pharmacia$\mathrm{LKB}^{\circledR}$ ) e a imagem era digitalizada em aparato de fotodocumentação. 


\subsubsection{Digestão do DNA plasmidial com enzimas de restrição.}

As digestões dos plasmídios utilizados foram realizadas com enzimas de restrição conforme instruções dos fabricantes. O tempo de incubação e a quantidade de material a ser digerido variavam de acordo com o interesse do experimento realizado.

\subsubsection{Eletroeluição de fragmentos de DNA em gel de agarose com o kit} comercial Ultrafree-DA Centrifugal Filter Unit (Millipore - número de catálogo 42600).

1 - Preparava- se o gel de agarose com tampão TAE 1x, de acordo com o tamanho da banda a ser eletroeluída.

2- O tempo e a velocidade a ser aplicada na corrida, também eram proporcionais ao tamanho da banda a ser eletroeluída. Em geral, a corrida era de 4 horas a 30Volts.

3- A banda correspondente ao fragmento de DNA a ser purificado era cortada do gel de agarose.

4 - A banda era embrulhada em um envelope de parafilme e depois congelada no freezer $-80^{\circ} \mathrm{C}$, por 20 minutos.

5 - Depois procedia- se com a maceração da banda embrulhada no envelope de parafilme, sem descongelar a agarose, a agarose congelada era transferida para as colunas do Ultrafree DA Centrifugal Unit (Millipore ${ }^{\circledR}$ ).

6- As colunas eram centrifugadas a $5000 \mathrm{~g}$ por 10 minutos e o sobrenadante coletado em microtubos.

7- Depois acrescentava- se 50 uL de buffer EB na coluna, e repetia o processo de centrifugação.

8- O líquido era coletado e acrescentado ao microtubo de coleta.

9- Após a centrifugação o material foi precipitado com a adição de $0,1 \vee$ de acetato de sódio 3M, $60 \mu \mathrm{g}$ de glicogênio e 2,5v etanol 100\% gelado. Procedeu-se a uma incubação a $-20^{\circ} \mathrm{C}$ durante a noite para um melhor rendimento da precipitação.

10- No outro dia, as amostras eram centrifugadas a $12.000 \mathrm{rpm}$ por $45 \mathrm{~min}$ a $4^{\circ} \mathrm{C}$. Desprezava-se o sobrenadante. 
11 - Eram adicionados $300 \mu \mathrm{L}$ de etanol $70 \%$ gelado e centrifugava- se novamente a 12.000 rpm por $15 \min$ a $4^{\circ} \mathrm{C}$.

12- Secava-se o sedimento a vácuo ou por simples exposição ao ar.

13- O sedimento foi ressuspendido em $15 \mu \mathrm{L}$ de água Milli $\mathrm{Q}$, e as amostras conservadas a $-4^{\circ} \mathrm{C}$.

\subsubsection{Precipitação de DNA utilizando glicogênio como carreador (Silva,} 2008).

O volume do material a ser precipitado foi aferido. Em seguida, acrescentouse, na ordem, $3 \mu \mathrm{L}$ de glicogênio $20 \mathrm{mg} / \mathrm{mL}, 1 / 10$ do volume de acetato de sódio 3M pH 5,0 e 2 volumes de etanol $100 \%$ gelado. O sistema de precipitação foi incubado a $-20{ }^{\circ} \mathrm{C}$ durante a noite. No dia seguinte, as amostras foram centrifugadas a $12.000 \times$ g por 45 minutos a $4{ }^{\circ} \mathrm{C}$. Descartou-se o sobrenadante e o sedimento foi lavado com $200 \mu \mathrm{L}$ de etanol $70 \%$ (v/v) gelado, centrifugando-se a $12.000 \times$ g por 15 minutos a $4^{\circ} \mathrm{C}$. O sobrenadante foi descartado e o sedimento foi deixado à temperatura ambiente por cerca de 15 minutos para secar.

\subsubsection{Ligação de fragmentos de DNA (Silva, 2008).}

As concentrações de DNA (vetor: inserto) utilizadas nos sistemas de ligação variaram de acordo com o experimento a ser realizado, sendo normalmente numa razão molar de 1:3 ou 1:5 e aplicando-se a fórmula:

$$
\frac{\text { ng vetor } X \text { tamanho do inserto em pb X razão inserto }}{\text { tamanho do vetor em pb }}=\underline{\text { ng de inserto }}
$$

As reações de ligação foram realizadas de acordo com instrução do fabricante da T4 DNA Ligase da Invitrogen. Após incubação, em geral de 16 horas a $4^{\circ} \mathrm{C}, \mathrm{os}$ sistemas de ligação eram usados para transformar células de E. coli. 


\subsubsection{Preparação de células competentes e transformação bacteriana.}

Adaptado do livro Técnicas Básicas de Biologia Molecular. Capitulo VIII (Maranhão, 2003).

$\checkmark$ Por choque térmico- $\mathrm{CaCl}_{2}$.

Preparava- se um pré-inóculo de $5 \mathrm{~mL}$ com tetraciclina na concentragão de $50 \mathrm{ug} / \mathrm{mL}$, com uma colônia isolada da célula XL1BLUE. Imcubava- se o inóculo durante 16 horas a $37^{\circ} \mathrm{C}$, sob agitação de 250 rpm.

Inoculavam-se $500 \mu \mathrm{L}$ do pré- inóculo em $50 \mathrm{~mL}$ de meio LB sem antibiótico. Incubava-se a $37^{\circ} \mathrm{C}$ com rotação de $220 \mathrm{rpm}$, até a cultura atingir uma densidade óptica a $600 \mathrm{~nm}\left(\mathrm{OD}_{600 \mathrm{~nm}}\right)$ de 0,1 a 0,3 .

Procedia- se com a centrifugação de $3.000 \times$ g por 15 min a $4^{\circ} \mathrm{C}$, desprezandose o sobrenadante e conservando as células em banho de gelo com água, procediase com :

- A centrifugação de $3.000 \times$ g por 15 min a $4^{\circ} \mathrm{C}$, desprezando-se 0 sobrenadante e conservando as células em banho de gelo com água.

O sedimento de células era ressuspendido em $10 \mathrm{~mL}$ de solução de $\mathrm{CaCl}_{2} 50 \mathrm{mM}$ estéril gelada, com movimentos suaves;

- Centrifugava-se a 3.000 x g por 15 min a $4^{\circ} \mathrm{C}$, desprezando-se 0 sobrenadante. $\mathrm{O}$ sedimento era ressuspendido em $1 \mathrm{~mL}$ de solução de $\mathrm{CaCl}_{2} 50 \mathrm{mM}$ estéril gelada, com movimentos suaves.

Após incubação de 1 hora em banho de água/gelo as células eram consideradas competentes, e procedia- se com o processo de transformação.

- Os sistemas de transformação eram realizados em tubos de hemólise vedados com parafilme (uma vez que, o vidro promove a troca de temperatura melhor do que o plástico) Incubavam-se de 100 a $200 \mu \mathrm{L}$ de célula competente com o plasmídio de interesse a ser transformado em banho de água/gelo por $30 \mathrm{~min}$.

- Procediam-se o choque térmico incubando-se o sistema de transformação em banho a $42^{\circ} \mathrm{C}$ por 3 min. 
- Adicionava-se imediatamente $1 \mathrm{~mL}$ de meio LB e incubava-se por $1 \mathrm{~h} \mathrm{a}$ $37^{\circ} \mathrm{C}$.

- Para semear as placas, eram utilizadas pérolas de vidro. Semeavamse quantidades variáveis do sistema de transformação em placas contendo meio LB-ágar contendo ampicilina a $200 \mu \mathrm{g} / \mathrm{mL}$. As placas eram mantidas na estufa a $37^{\circ} \mathrm{C}$ por 16 horas.

\section{Por eletroporação.}

Uma colônia isolada da célula de interesse foi inoculada em $10 \mathrm{~mL}$ de meio SB contendo o antibiótico de interesse. Esse pré-inóculo era mantido a $37^{\circ}$ sob agitação de 220 rpm por 16 horas.

Inoculava-se $1 \mathrm{~mL}$ do pré-inóculo em $500 \mathrm{~mL}$ de meio $\mathrm{SB}$ contendo $2,5 \mathrm{~mL}$ da solução estoque de glicose $2 \mathrm{M}$ e 2,5 mL da solução estoque de $\mathrm{Mg} 2 \mathrm{M}$. Incubava-se a $37^{\circ} \mathrm{C}$ a $220 \mathrm{rpm}$ até a cultura atingir uma $\mathrm{OD}_{600 \mathrm{~nm}}$ de 0,7 a 0,9. Posteriormente:

- Centrifugava-se a $3.000 \times \mathrm{g}$ por $20 \mathrm{~min}$ a $4^{\circ} \mathrm{C}$, desprezando-se 0 sobrenadante e mantendo sempre a célula gelada a partir desse momento.

- O sedimento era ressuspendido em $25 \mathrm{~mL}$ de glicerol $10 \%$ estéril gelado e a seguir adicionava-se mais $75 \mathrm{~mL}$ de glicerol $10 \%$ gelado.

- Centrifugava-se a 3.000 x g por 20 min a $4^{\circ} \mathrm{C}$, repetindo-se a etapa anterior.

- O sedimento era ressuspendido em $25 \mathrm{~mL}$ de Gilcerol $10 \%$ estéril gelado e submetido a última centrifugação a $3.000 \times \mathrm{g}$ por $20 \mathrm{~min}$ a $4^{\circ} \mathrm{C}$.

- O sedimento final era ressuspendido em 1 a $2 \mathrm{~mL}$ de glicerol $10 \%$ e as células eram aliquotadas, congeladas em banho de gelo seco com etanol e armazenadas imediatamente a $-80^{\circ} \mathrm{C}$.

- Para a transformação, o plasmídio, já em um tubo resfriado previamente, era adicionado à célula competente e imediatamente colocado na cubeta de eletroporação (BioRad ${ }^{\circledR}$ ) também já resfriadas.

- A eletroporação era feita seguindo os seguintes parâmetros elétricos: $2,5 \mathrm{kV}$, $25 \mu \mathrm{F}$ e $200 \Omega$, no aparelho Gene Pulser com Pulser Controller da BioRad. O т esperado nessas condições era de 4,0 a 5,0 milisegundos. 
- Imediatamente após o choque a cubeta era lavada com $3 \mathrm{~mL}$ de meio SOC e o meio era recolhido para um tubo de centrifugação de $50 \mathrm{~mL}$.

- Após uma incubação de $1 \mathrm{~h}$ a $37^{\circ} \mathrm{C}$ e $220 \mathrm{rpm}$, diluições da transformação eram semeadas em placas contendo ampicilina a $200 \mu \mathrm{g} / \mathrm{mL}$. As placas eram mantidas na estufa a $37^{\circ} \mathrm{C}$ por 16 horas.

\subsubsection{Condições e preparo da Reação de Polimerização em Cadeia (PCR).}

Os oligonucleotídeos com as seqüências controles e indutoras estão listados em materiais. A reação de polimerização em cadeia ( $P C R)$ foi realizada com a enzima Taq DNA Polymerase 100u da Invitrogen (Número de catálogo 18038-018).

\section{Condições da PCR}

\begin{tabular}{|c|c|c|}
\hline Reação & Temperatura & Tempo \\
\hline 1- Temperatura de Desnaturação & $95^{\circ} \mathrm{C}$ & $5 \mathrm{~min}$. \\
\hline 2- Temperatura de Desnaturação & $95^{\circ} \mathrm{C}$ & $1 \mathrm{~min}$. \\
\hline 3- Temperatura de Anelamento & $55^{\circ} \mathrm{C}$ & $1 \mathrm{~min}$. \\
\hline 4-Temperatura de Extensão & $72{ }^{\circ} \mathrm{C}$ & $1 \mathrm{~min}$. \\
\hline 5 Repetiu- se 29 vezes a partir do 2 & \\
\hline 6- Temperatura de Extensão & $72{ }^{\circ} \mathrm{C}$ & $5 \mathrm{~min}$. \\
\hline 7 - End & $4{ }^{\circ} \mathrm{C}$ & - \\
\hline
\end{tabular}




\section{Preparo da PCR}

\begin{tabular}{|c|c|c|c|c|c|c|c|c|}
\hline $\begin{array}{l}\text { DNA } \\
10 \mathrm{ng}\end{array}$ & $\begin{array}{c}\text { Primer } \\
\mathbf{5} \text { ' } \\
X \mathrm{ma} I \\
10 \mathrm{uM}\end{array}$ & $\begin{array}{c}\text { Primer } \\
\text { 3' } \\
\text { Xba I } \\
10 \text { uM }\end{array}$ & $\begin{array}{l}\text { dNTP } \\
10 \mathrm{mM}\end{array}$ & $\begin{array}{l}\mathrm{MgCl} 2 \\
50 \mathrm{mM}\end{array}$ & $\begin{array}{l}\text { Buffer } \\
\text { Taq. } \\
10 x\end{array}$ & $\begin{array}{l}\text { Taq. } \\
1 \mathrm{uL}\end{array}$ & $\begin{array}{l}\text { H2O } \\
\text { Milli } Q\end{array}$ & Vol.Total \\
\hline $1 \mathrm{uL}$ & $3 \mathrm{uL}$ & - & $5 \mathrm{uL}$ & $2 \mathrm{uL}$ & $5 \mathrm{uL}$ & $1 \mathrm{uL}$ & $34 \mathrm{uL}$ & $50 \mathrm{uL}$ \\
\hline $1 \mathrm{uL}$ & - & $3 \mathrm{uL}$ & $5 \mathrm{uL}$ & $2 \mathrm{uL}$ & $5 \mathrm{uL}$ & $1 \mathrm{uL}$ & $34 \mathrm{uL}$ & $50 \mathrm{uL}$ \\
\hline $1 \mathrm{uL}$ & $3 \mathrm{uL}$ & $3 \mathrm{uL}$ & $5 \mathrm{uL}$ & $2 \mathrm{uL}$ & $5 \mathrm{uL}$ & $1 \mathrm{uL}$ & $31 \mathrm{uL}$ & $50 \mathrm{uL}$ \\
\hline
\end{tabular}

\begin{tabular}{|c|c|c|c|c|c|c|c|c|}
\hline $\begin{array}{l}\text { DNA } \\
10 \mathrm{ng}\end{array}$ & $\begin{array}{c}\text { Primer } \\
\mathbf{5}^{\prime} \\
B g \mathrm{l} / \\
10 \mathrm{uM}\end{array}$ & $\begin{array}{c}\text { Primer } \\
\text { 3' } \\
\text { Xho I } \\
10 \text { uM }\end{array}$ & $\begin{array}{l}\text { dNTP } \\
10 \mathrm{mM}\end{array}$ & $\begin{array}{l}\text { MgCl2 } \\
50 \mathrm{mM}\end{array}$ & $\begin{array}{l}\text { Buffer } \\
\text { Taq. } \\
10 x\end{array}$ & $\begin{array}{l}\text { Taq. } \\
1 \mathrm{uL}\end{array}$ & $\begin{array}{c}\mathrm{H} 2 \mathrm{O} \\
\text { Milli } Q\end{array}$ & Vol.Total \\
\hline $1 \mathrm{uL}$ & $3 \mathrm{uL}$ & & $5 \mathrm{uL}$ & $2 \mathrm{uL}$ & $5 \mathrm{uL}$ & $1 \mathrm{uL}$ & $34 \mathrm{uL}$ & $50 \mathrm{uL}$ \\
\hline $1 \mathrm{uL}$ & - & $3 \mathrm{uL}$ & $5 \mathrm{uL}$ & $2 \mathrm{uL}$ & $5 \mathrm{uL}$ & $1 \mathrm{uL}$ & $34 \mathrm{uL}$ & $50 \mathrm{uL}$ \\
\hline $1 \mathrm{uL}$ & $3 \mathrm{uL}$ & $3 \mathrm{uL}$ & $5 \mathrm{uL}$ & $2 u L$ & $5 \mathrm{uL}$ & $1 \mathrm{uL}$ & $31 \mathrm{uL}$ & $50 \mathrm{uL}$ \\
\hline
\end{tabular}

\subsubsection{Cultura de células de mamíferos}

Durante toda a manutenção da cultura, as células eram observadas em microscópio invertido de contraste de fase NIKON DIAPOH e incubadas na estufa a $37{ }^{\circ} \mathrm{C}, 5 \%$ de $\mathrm{CO}_{2}$ e $70 \%$ de umidade. O meio utilizado foi o HamF12 da Gibico (para preparo), com adição de bicarbonato para manutenção do pH. O meio quando em cultura era suplementado com Soro Fetal Bovino a diferentes concentrações, sendo utilizado o Soro Fetal Bovino Low IgG a 1,25\% durante o acumúlo de sobrenadante. 


\subsubsection{Descongelamento de células CHO-K1 e passagem de células (Silva,} 2008).

1- Primeiramente, descongelou- se a $37^{\circ} \mathrm{C}$ criotubos com alíquotas de células $\mathrm{CHO}$ $\mathrm{K} 1$ preservadas em nitrogênio líquido, colocou- se em meio Ham-F12 acrescido de soro fetal bovino $20 \%$.

2- Centrifugou- se a 1.300 rpm por 5 minutos.

3- As células foram ressuspendidas e depois plaqueadas na densidade de $2 \times 10^{2}$ por garrafa de $25 \mathrm{~cm}^{2}$ em meio Ham-F12 acrescido de $10 \%$ SFB com antibióticoantimicótico $1 \%$ e incubadas a $37^{\circ} \mathrm{C}, 5 \%$ de $\mathrm{CO}_{2}$ e $70 \%$ de umidade.

\subsubsection{Tripsinização, passagem das células e formação de monocama} celular (Silva, 2008).

Após o descongelamento e passagem para as garrafas de $25 \mathrm{~cm}^{2}$, quando as células atingiam a confluência total de $100 \%$ elas eram tripsinizadas e transferidas para garrafas de $75 \mathrm{~cm}^{2}$, posteriormente quando atingiarm $100 \%$ de confluência além da tripsinização e da transferência para garrafa maior de $150 \mathrm{~cm}^{2}$, também era realizado o congelamento de alíquotas. $O$ protocolo para tripsinização tem poucas modificações em relação ao tamanho da garrafa:

1 - O meio de cultura da garrafa era descartado.

2 - Eram adicionados $3 \mathrm{~mL}$ de tripsina para garrafas com $25 \mathrm{~cm}^{2}$, para garrafas com $75 \mathrm{~cm}^{2} 5 \mathrm{~mL}$, e para garrafas com $150 \mathrm{~cm}^{2} 7 \mathrm{~mL}$. Logo após a adição de tripsina, as garrafas eram homogeneizadas até a tripsina ficar um pouco turva.

4 - Após 3 minutos, as células começaram a se descolar da superfície da garrafa. $O$ descolamento das células era acompanhado por visualização a olho nu.

5 - Para neutralizar a ação da tripsina, acrescia- se o dobro de meio cultura do que foi colocado de tripsina, o meio utilizado era suplementado com $30 \%$ de SFB.

6 - A suspensão celular era transferida para tubos tipo falcon de $50 \mathrm{~mL}$, e centrifugados a 1.300 rpm por 8 minutos. 
7 - O sobrenadante era descartado e o sedimento ressuspenso em $3 \mathrm{~mL}$ de meio acrescido de $10 \%$ SFB.

8 - Era transferida toda a população células para garrafas de: $25 \mathrm{~cm}^{2}, 75 \mathrm{~cm}^{2}$ ou 150 $\mathrm{cm}^{2}$ contendo respectivamente: 5,10 , ou $20 \mathrm{~mL}$ de meio HamF12 acrescido de $10 \%$ SFB.

9-. Foram realizadas 5 passagens para garrafas de $150 \mathrm{~cm}^{2}$.

\subsubsection{Congelamento de células $\mathrm{CHO}$ - Criopreservação (Ruggiero,} 2002).

1 - As células em cultura aderente eram tripsinas, como descrito no item anterior.

2 - A suspensão celular era então transferida para um tubo de centrifuga de $50 \mathrm{~mL}$, ao qual se adicionava- se o dobro de meio Ham-F12 acrescido de $10 \%$ de Soro fetal bovino (SFB), para a inativação da tripsina que é nociva as células.

3 - As células eram centrifugadas a 1300 rpm por 8 minutos.

4 - O sobrenadante era descartado e o sedimento ressuspenso no meio de cultura remanescente do tubo.

5 - As células eram ressuspendidas com $5 \mathrm{~mL}$ de meio para congelamento, preparado na seguinte proporção: $45 \%$ de meio HamF12, $45 \%$ de SFB e $10 \%$ de DMSO (dimetilsulfóxido).Depois, distribuídas em alíquotas de $500 \mu \mathrm{L} \mathrm{em}$ criotubos. 6 - Os criotubos eram incubados a $4 \stackrel{\circ}{\circ} \mathrm{C}$ por 30 minutos, depois a $-20 \stackrel{\circ}{\mathrm{C}}$ por 30 minutos e depois a - $80^{\circ} \mathrm{C}$ durante a noite. As células poderiam permanecer estocadas a esta temperatura ou ser transferidas para a estocagem em nitrogênio líquido.

\subsubsection{Determinação da viabilidade celular por meio da contagem em} câmara de Neubauer (Silva, 2008).

1 - As células foram tripsinizadas e transferidas para um tubo falcon de $15 \mathrm{~mL}$, ao qual se adicionou $5 \mathrm{~mL}$ de meio Ham F12 com SFB a $10 \%$.

2 - As células foram centrifugadas a $1300 \times \mathrm{g}$ por 8 minutos. 
3 - O sobrenadante era descartado e as células ressuspensas em $3 \mathrm{~mL}$ de meio de cultura Ham F12 com SFB a $10 \%$.

4 - Vinte microlitros da suspensão celular eram incubados com $80 \mu \mathrm{L}$ da solução de Azul de Tripan (diluição de 5 vezes da cultura).

5 - A câmara de Neubauer era montada, e nela aplicou-se um volume de $10 \mu \mathrm{L}$ da mistura.

6 - Eram contadas 200 células, entre viáveis (transparentes) e não-viáveis (azuis). A célula não-viável tem a membrana celular mais permeável, e por isso, o corante entra na célula, tornando-a azul.

3.2.14 Estimativa do número de células por meio de contagem em câmara de Neubauer (Silva, 2008).

1 - As células eram tripsinizadas e ressuspensas em $1 \mathrm{~mL}$ de meio de cultura.

2 - A câmara de Neubauer era coberta com a lamínula e eram aplicados $10 \mu \mathrm{L}$ de suspensão de células em cada compartimento da Câmara. Caso alguma diluição tivesse sido necessária, o número de células contado era multiplicado por esse fator de diluição.

3 - As células eram observadas em microscópio óptico (na objetiva com aumento de 40 vezes) e contadas nos 4 quadrantes externos. Em seguida, era utilizada a fórmula:

número de células contadas $X$ fator de diluição $X 10^{4}=n^{0}$ de células $/ \mathrm{mL}$ número de quadrantes contados

\subsubsection{Transfecção de Células $\mathrm{CHO}$ utilizando o reagente JetPEI ${ }^{\mathrm{TM}}$ (Polyplus Transfection, no de catálogo 101-01N).}

O reagente JetPEI consiste em um polímero catiônico derivado de polietilenimina linear, e tem como objetivo inibir a formação de complexos de DNA, permitindo a transfecção do DNA na célula.

1- Após as 5 passagens de células $\mathrm{CHO}-\mathrm{K} 1$, plaqueo- se $2 \times 10^{4}$, de células viáveis com $2 \mathrm{~mL}$ de meio HAM e SFB 10\% em placas para cultura de células com 6 poços. 
Essas células foram transfectadas quando atingiam uma confluência na placa entre 50 a $60 \%$, essa confluência ocorria após 24 horas.

2- Para transfectar as células $\mathrm{CHO}-\mathrm{K} 1$, placas de 6 poços foram divididas em três grupos de acordo com a versão do plasmídio pCOMIRES $\triangle 600$ : placas $A$ foram transfectadas com o plasmídio pCOMIRES $\triangle 600$ versão A (Vk A27/ humanVH1-46), placas $O$ com plasmídio pCOMIRES $\triangle 600$ versão $\mathrm{O}(\mathrm{V}$ am4/ mouse VH J558.4) e, placas $L$ com o plasmídio pCOMIRES $\triangle 600$ versão L (V kL1/ humanVH1-46).

3- Cada placa de cultura foi semeadas cerca de $2 \times 10^{4}$ células por poço, adicionando-se em seguida $2 \mathrm{~mL}$ de meio acrescido de $10 \%$ SFB e solução de antibiótico/antimicótico.

4- As células foram incubadas na estufa a $37^{\circ} \mathrm{C}, 5 \%$ de $\mathrm{CO}_{2}$ e $70 \%$ de umidade durante a noite, até que se atingisse a confluência ideal de 50 a $60 \%$.

5- Para a transfecção de Células $\mathrm{CHO}$ em placas de 6 poços, as células tinham aproximadamente $60 \%$ de confluência no momento da transfecção.

6- Foi diluído $1 \mu \mathrm{g}$ de DNA em $100 \mu \mathrm{l}$ do buffer jetPEl тм em um microtubo.Homogeneizou- se e o microtubo foi agitado no vórtex por 10 segundos.

7- Em seguida adicionou- se $2 \mu \mathrm{l}$ de reagente jetPRIME TM. Agitou- se no vórtex, por $10 \mathrm{~s}$, e homogeneizou- se por spin rapidamente.

8- Incubou- se por 10 min à temperatura ambiente.

9- Posteriormente, foram adicionados $100 \mu \mathrm{l}$ da mistura de transfecção, gota a gota, por poço com as células em meio de crescimento celular normal.

10- Homogeneizou- se suavemente as placas para trás e para os lados..

11- Após $4 \mathrm{~h}$ de transfecção o meio de crescimento foi trocado e as placas retornavam para estufa a $37^{\circ}$.

12- $O$ resultado era analisado 48 horas depois.

\subsubsection{Seleção de células transfectadas utilizando Geneticina ${ }^{\circledR}$ (G418-} Sulfato).

1 - Após 48 horas da transfecção o meio foi trocado por outro com geneticina a uma concentração de $400 \mu \mathrm{g} / \mathrm{mL}$ em todos os poços transfectados com o plasmídio e também nos poços controle, com células não transfectadas. 
2- Após 48 horas, foi realizada outra troca de meio, mas com a concentração de geneticina a $600 \mu \mathrm{g} / \mathrm{mL}$.

3 - Posteriormente o meio de cultura foi trocado a cada 2 dias nas mesmas condições descritas anteriormente e visualizava-se, ao microscópio ótico, a morte celular no poço controle de células não transfectadas, que ocorre quando essas células mudam sua morfologia de elípticas para esféricas e perdem a aderência à placa de cultura.

4- Quando observava- se a morte das células não transfectadas e que as células nos poços transfectados com os plasmídios atingiram uma confluência de aproximadamente $60 \%$, essas células passavam para as garrafas de $15 \mathrm{~cm} 2$.

\subsubsection{Análises dos sobrenadantes de cultura em placas de microtitulação por meio de ELISA.}

Eram realizadas análises dos sobrenadantes de cultura em placas de microtitulação por meio de ELISA sandwíche, utilizando os anticorpos descritos na seção de materiais. As placas permaneciam vedadas durante as incubações, e após as etapas de lavagens, elas eram invertidas e batidas em uma pilha de papel toalha. Três poços eram utilizados como background, onde procedia- se com a incubação de PBS.

1- As placas eram sensibilizadas com 150uL do anticorpo de Cabra anti- IgG humana $(\mathrm{H}+\mathrm{L})$ diluído com PBS em 1:1000.

2- Após 2 horas de sensibilização, as placas eram lavadas 3 vezes com 200 uL de tampão PBST.

3- Incubavam- se as placas com 200 uL de solução bloqueio (PBS com $5 \%$ de leite em pó) em temperatura ambiente por 2 horas.

4- Após a incubação, as placas eram lavadas 3 vezes com 200 uL de tampão PBST.

5- As amostras eram colocadas nos poços: as diluições tanto da curva padrão como das amostras eram: 1:1, 1:3, 1:9, 1:27, 1:81. A curva padrão era realizada com a IgG humana, e iniciava- se na concentração de $113 \mathrm{ng} / \mathrm{mL}$.

6- As amostras eram incubadas a temperatura ambiente por 2 horas.

7- Após a incubação, as placas eram lavadas 3 vezes com 200 uL de tampão PBST. 
8- Depois, acrescentavam- se $150 \mathrm{uL}$ do anticorpo de Cabra anti-Fc humana conjugado com fosfatase alcalina, na diluição de 1:5000.

9- As amostras eram incubadas a temperatura ambiente por 2 horas

10- Após a incubação, as placas eram lavadas 3 vezes com 200 uL de tampão PBST e uma vez com 200 uL de tampão APB (tampão para fosfatase alcalina).

11- Preparava- se a solução reveladora utilizando o Kit pNPP ( $p$-nitrophenyl phosphate) da Thermoscientifc, e depois acrescentava- se 200 uL desta solução em todos os poços.

12- Procedia- se com a leitura dos posços após incubação de 3 minutos com a placa embrulhada em papel alumínio. A leitura era realizada no leitor de ELISA Microplate reader Biorad, modelo 450 a um comprimento de onda de $405 \mathrm{~nm}$. Eram considerados os valores do controle com PBS e os valores da curva padrão para realizar os cálculos das concentrações dos sobrenadantes.

\subsubsection{Purificação de Proteínas com a coluna His Trap da GeHealthCare} e concentração das amostras eluídas com a coluna Centricon da Millipore.

1- Primeiramente foi montada a bomba peistáltica para ser utilizada com a coluna.

2- Desempacotou-se a resina na coluna, e depois colocou- se a coluna em posição vertical até que ela voltasse a ficar empacotada.

3- Abriu- se a mangueira da bomba peristáltica e filtrou- se $10 \mathrm{~mL}$ de Biding Buffer.

4- Posteriormente, foi colocado o sobrenadante diluído na proporção de 1:1 com Biding Buffer;

5- Assim que todo o sobrenadante foi passado pela coluna, colocou-se $30 \mathrm{~mL}$ de Biding Buffer.

6- Após a passagem dos $30 \mathrm{~mL}$, foi colocado $20 \mathrm{~mL}$ de Elution Buffer.

7-A eluição foi coletada em 20 microtubos.

8- Depois foram passados mais $10 \mathrm{~mL}$ de Biding Buffer na coluna.

9- Após este processo a coluna foi lavada com água Milli Q. com azida sódica a $0,5 \%$.

10- Posteriormente foram feitas análises por Dot Blot das frações eluídas da coluna.

11- Procedeu- se a concentrão das amostras com a coluna Centricon da Millipore.

12- A coluna foi centrifugada a $7.500 \mathrm{~g}$ por 10 minutos com tampão PBS. 
13- Depois ineverteu- se a coluna e colocou- se as amostras diluídas 1:1 com tampão PBS.

14- Centrifugou- se a $7.500 \mathrm{~g}$ por 10 minutos com tampão PBS.

15- Coletou- se as amostras em microtubos.

\subsubsection{Análise de proteínas em gel de poliacrilamida desnaturante} Adaptado do livro Técnicas Básicas de Biologia Molecular. Capitulo XII (SilvaPereira, 2003).

A eletroforese unidimensional em gel SDS- PAGE (SDS- PAGE: Sodium Dodecyl Sulphate- Polyacrilamide Gel Eletrophoresis) foi utilizada para determinar a massa molecular dos FvFcs recombinantes após as etapas de purificação. Foram preparados dois géis SDS- PAGE, um foi corado com a coloração de prata, e o outro foi transferido para uma membrana de nitrocelulose para ser feito o Western- Blot.

1- Primeiramente foi montado o aparato de eletroforese: limpeza das placas, montagem das placas com os espaçadores laterais.

2- Preparou- se a solução do gel separador na concentração de $12 \%$ de policacrilamida (proporcional a $55 \mathrm{kDa}$ ), removeu- se bolhas com butanou e depois lavou- se o gel com água Milli $Q$.

3- Manteu- se a placa em posição vertical, até que a polimerização do gel terminasse.

4- Preparou- se a solução com o gel concentrador, vertendo sobre o gel separador e, introduzindo o pente para a formação de poços.

5- Após a polimerização do gel concentrador, removeu- se o pente.

6- Posteriormente as amostras foram preparadas: adicionou- se o tampão de amostras contendo $\beta$ - mercaptoetanol $4 \%$, e depois cada amostra foi fervida a $100^{\circ} \mathrm{C}$ durante 5 minutos.

7- As amostras foram aplicadas nos poços com os marcadores. Descritos em materiais.

8- As condições de migração do gel foram: $20 \mathrm{~mA}$ (miliampéres), voltagem $300 \mathrm{v}$, durante 4 horas. 


\subsubsection{Coloração do gel SDS-PAGE com o kit comercial Proteo Silver}

\section{Stain da Sigma.}

1- Após a eletroforese o gel SDS- PAGE foi fixado por 40 minutos com a solução de fixação em uma placa de petri de vidro;

2- Depois a solução de fixação foi desprezada e o gel foi lavado com $100 \mathrm{~mL}$ de etanol $30 \%$ por 10 minutos.

3- Lavou- se o gel com 100mL de água Milli $Q$.

4- Imcubou- se o gel com a solução de sensibilização por 10 minutos.

5- Depois a solução de sensibilização foi desprezada e colocou- se $100 \mathrm{~mL}$ da solução equilibrada com prata, por 10 minutos.

6- Desprezou- se a solução e incubou- se com água Milli Q. por 1 minuto.

7- Depois a água foi desprezada e incubou- se o gel com a solução reveladora por 10 minutos.

8- Após o aparecimento das bandas do gel SDS- PAGE, adicionou- se $5 \mathrm{~mL}$ da solução Stop Proteo Silver.

9. Depois a solução foi desprezada e o gel foi armazenado com água Milli $Q$.

\subsubsection{Análise das proteínas recombinantes por Western Blot}

Adaptado do livro Técnicas Básicas de Biologia Molecular. Capitulo XIII (Brígido, 2003).

Após realizada a corrida do gel SDS- PAGE, um dos géis preparados no item 3.2.20, foi transferido para uma membrana da nitrocelulose.

1- Foram cortados 12 pedaços de papel filtro Whatmam e uma pedaço de membrana de nitrocelulose (todos do tamanho do gel que foi transferido).

2- A membrana de nitrocelulose e os papeis filtros, foram molhados com o tampão de transferência.

3- Montou-se um sanduíche com os papeis filtros e a membrana de nitrocelulose com o gel no meio. E colocou- se sobre o eletrodo de grafite.

4- A transferência do gel procedeu- se com 80 mA, $10 \mathrm{~V}$, por cerca de duas horas. 
5- Após o gel ser transferido para a membrana de nitrocelulose, a membrana foi incubada por 2 horas com a solução bloqueio (PBS com 5\% de leite em pó Molico).

6- A membrana de nitrocelulose foi lavada com PBST por 3 vezes.

7- Após as lavagens, incubou- se por 2 horas o anticorpo conjugado com fosfatase alcalina, $F\left(a b^{\prime}\right) 2-G o a t$ anti-Human IgG Fc.

8- Depois foram feitas 3 lavagens com PBST.

9- Após as lavagens adicionou- se a solução reveladora Immun-Blot ${ }^{\circledR} \mathrm{Opti-} 4 \mathrm{CN}^{\mathrm{TM}}$ da Bio rad. 


\section{$\underline{\text { Resultados e Discussão }}$}




\subsection{Clonagem dos scFvs humanizados e murino no vetor de expressão pCOMIRES $\triangle 600$.}

Como descrito na introdução, foram sintetizadas quimicamente no vetor pBSK duas versões scFvs humanizadas e uma versão scFv murina similar a do Rituximabe

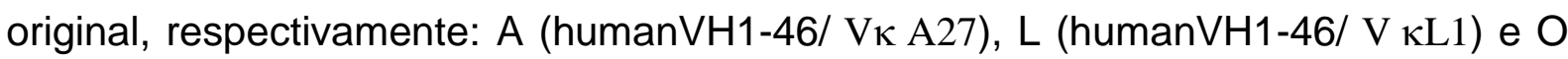
(VHJ558.4/Vкат4). Primeiramente, o vetor de escolha para as etapas de clonagens foi o vetor de expressão em células de mamíferos pCOMIRES $\triangle 600$ desenvolvido por Quilici (2008). Este vetor possibilitou a produção heteróloga das proteínas recombinantes em células de mamíferos. Nos desenhos gênicos foram inseridos sítios para clivagem com enzimas de restrição, de forma a possibilitar a clonagem no vetor pCOMIRES $\triangle 600$ (Quilici, 2008). As versões scFvs sintetizadas quimicamente no vetor pBSK, e os sítios para clivagem dos scFvs correspondem as endonucleases Xma I e Xho I, presentes também em sítios únicos no vetor pCOMIRES $\Delta 600$, com uma versão scFv anti-CD3 humanizada.

$O$ vetor pCOMIRES $\triangle 600$ possui os genes que codificam os domínios $\mathrm{CH} 2 \mathrm{e}$ $\mathrm{CH} 3$ do fragmento cristalizável de imunoglobulina humana IgG, que estão presentes entre o sítio da enzima Xho I e da enzima $E c o R I$, de forma que a proteína liberada pela célula de mamífero corresponda ao fragmento FvFc do anticorpo (Silva et.al., 2009). O vetor pCOMIRES $\triangle 600$, também possui: gene para resistência á ampicilina (bla), que facilita a manipulação em bactéria e o gene $\mathrm{NEO}^{\mathrm{R}}$ que confere as células $\mathrm{CHO}$ resistência á geneticina, com isso selecionando transfectomas estáveis (Silva et.al., 2009). Outra característica importante é que o gene de resistência a geneticina $\left(\right.$ NEO $^{\mathrm{R}}$ ) está clonado a jusante ao elemento IRES (Internal Ribossome Entry Site).

Nas etapas de clonagens das versões e também na amplificação dos plasmídios originais, foram utilizadas células Escherichia coli, linhagem XL1BLUE, a qual possui o gene de resistência à tetraciclina. As extrações e purificações de DNA plasmídial em pequena escala foram feitas com os protocolos experimentais descritos em materiais e métodos, e as extrações em grande escala foram realizadas com Kit Quiagen. Após as extrações, os plasmídios foram clivados com as enzimas Xma I e Xho I, o vetor e os fragmentos foram eletroeluídos em gel de agarose preparados com tampão TAE. Posteriormente os fragmentos scFvs foram 
ligados ao vetor pCOMIRES $\triangle 600 \mathrm{com}$ T4 DNA ligase da Invitrogen. Esta estratégia de clonagem encontra- se representada na figura 10. 


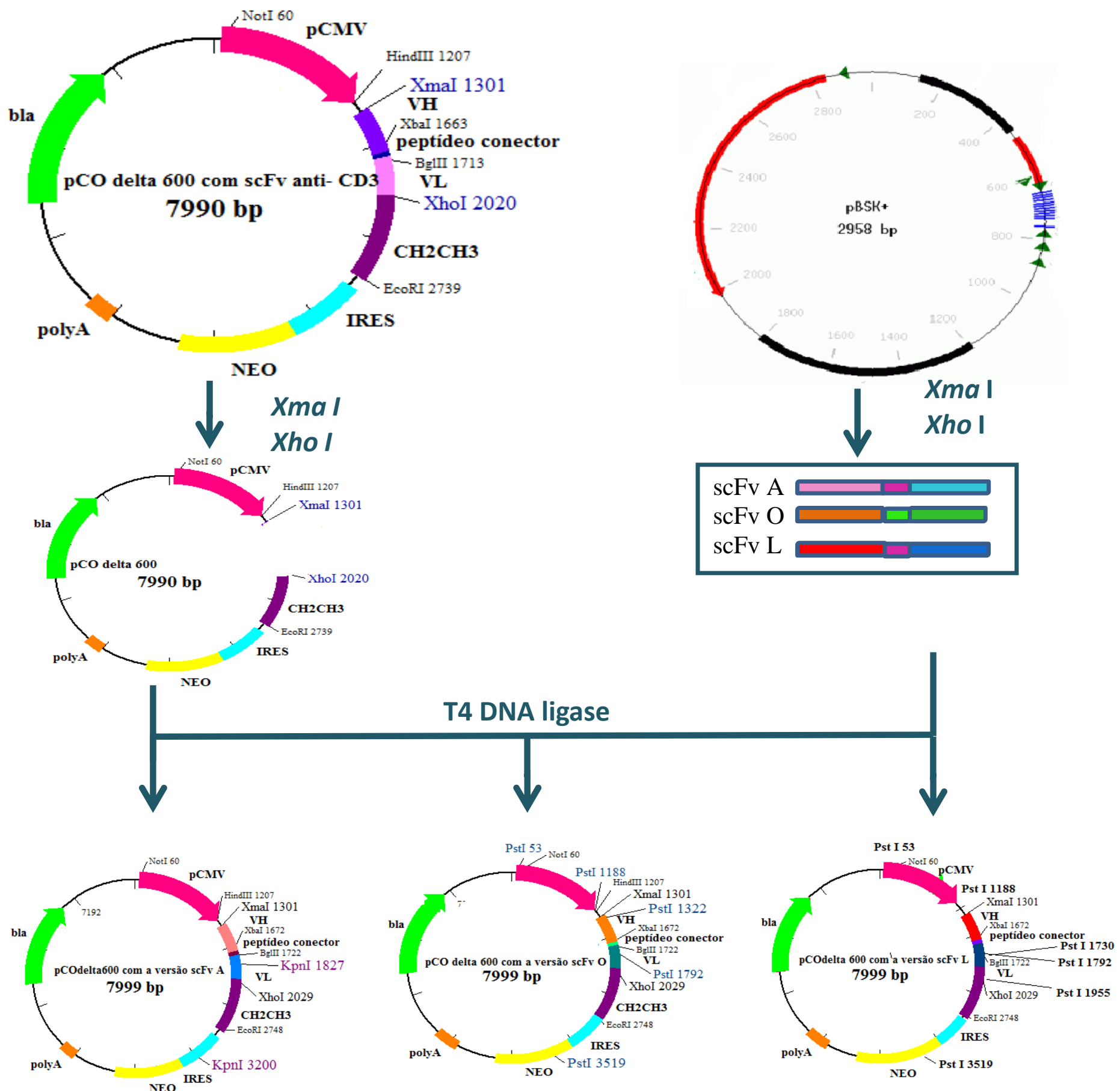

Figura 10. Desenho esquemático da estratégia de clonagem com o vetor de expressão em células de mamíferos pCOMIRES $\Delta 600$. Demonstração da clivagem dos vetores com as endonucleases Xma I e Xho I. Os fragmentos scFvs foram ligados, individualmente, ao vetor pCOMIRES $\triangle 600$ com T4 DNA ligase. Componentes do vetor pCOMIRES $\triangle 600$ : bla (gene de resistência a ampicilina), pCMV (peptídeo sinal), genes para fração Fc de $\lg G(\mathrm{CH} 2 \mathrm{CH} 3)$, IRES, NEO ${ }^{\mathrm{R}}$, e poly $\mathrm{A}$. 
A

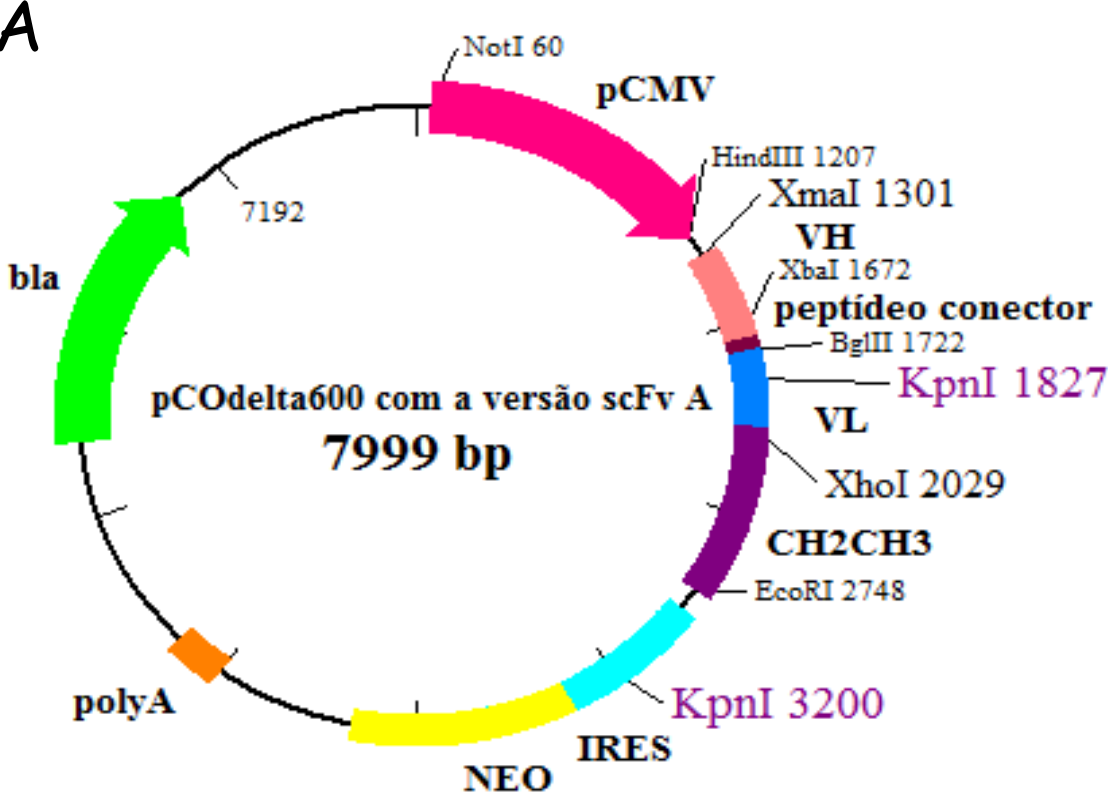

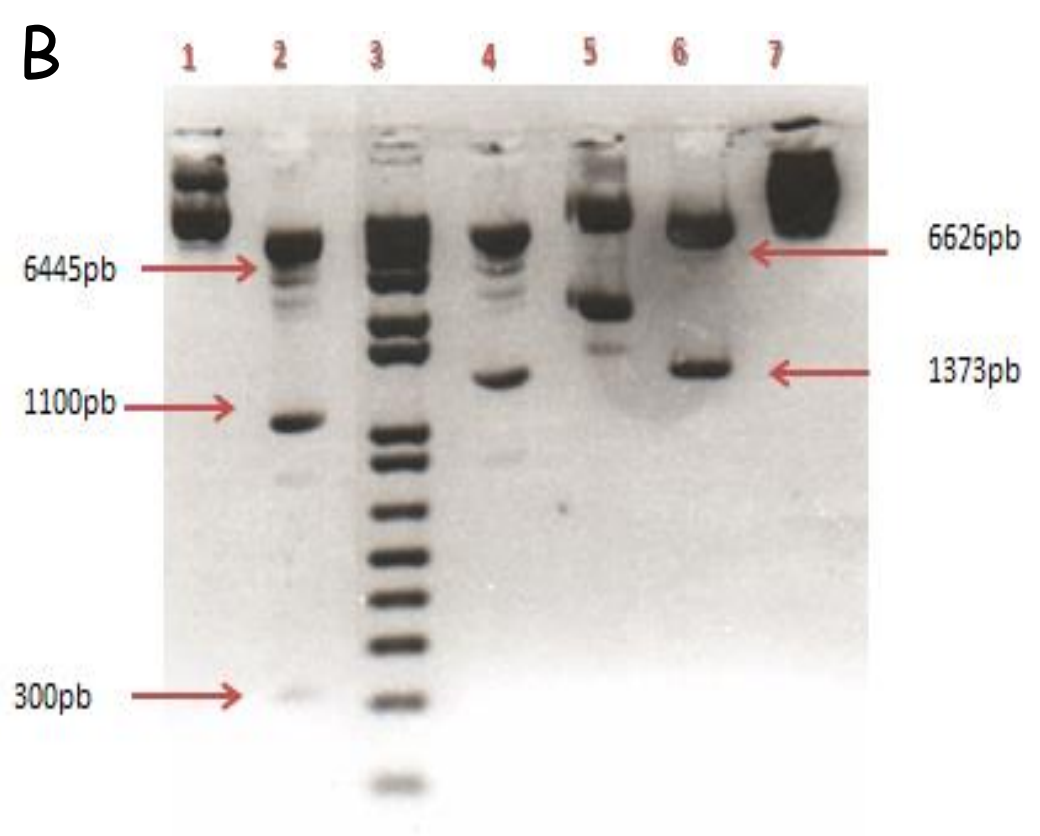

Figura 11. Desenho esquemático do vetor pCOMIRES $\Delta 600 \mathrm{com}$ a versão humanizada $\mathrm{scFv} A$ e análise comparativa do perfil de restrição em gel de agarose. Em A desenho esquemático do vetor pCOMIRES $\triangle 600$ com a versão humanizada scFv A (human VH1-46/VkA27); B: foram realizadas digestões com a enzima Kpn I para diferenciar os clones recombinantes do plasmídio parental original (pCOMIRES $\triangle 600$ versão scFv anti- CD3), 1- : pCOMIRES $\triangle 600$ anti-CD3 intacto; 2- : pCOMIRES $\triangle 600$ anti-CD3 digerido com Kpn I (bandas:6445, 1100, 300); 3-:1kb DNA ladder Plus (Invitrogen); 4-: pCOMIRES $\triangle 600$ scFv A intacto; 5: pCOMIRES $\triangle 600$ scFv A digerido com Kpn I (bandas: 6626,1373); 6: : pCOMIRES $\Delta 600$ scFv A digerido com Kpn I (bandas: 6626,1373) ; 7-: pCOMIRES $\Delta 600$ scFv A intacto. 
A

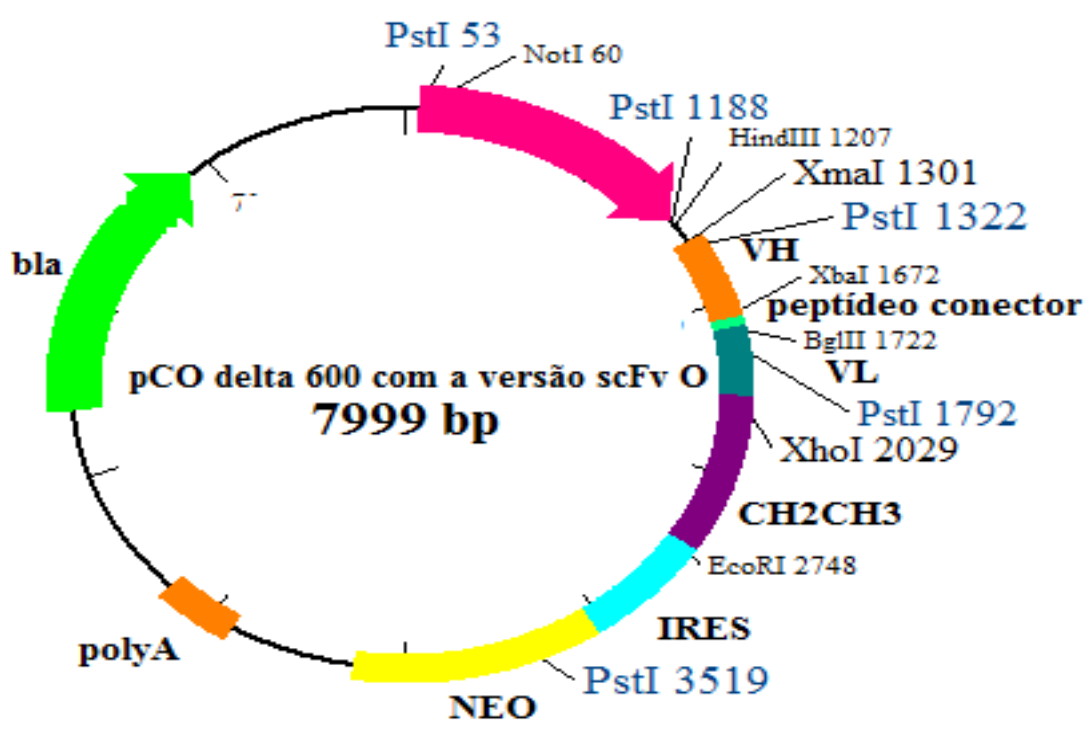

B

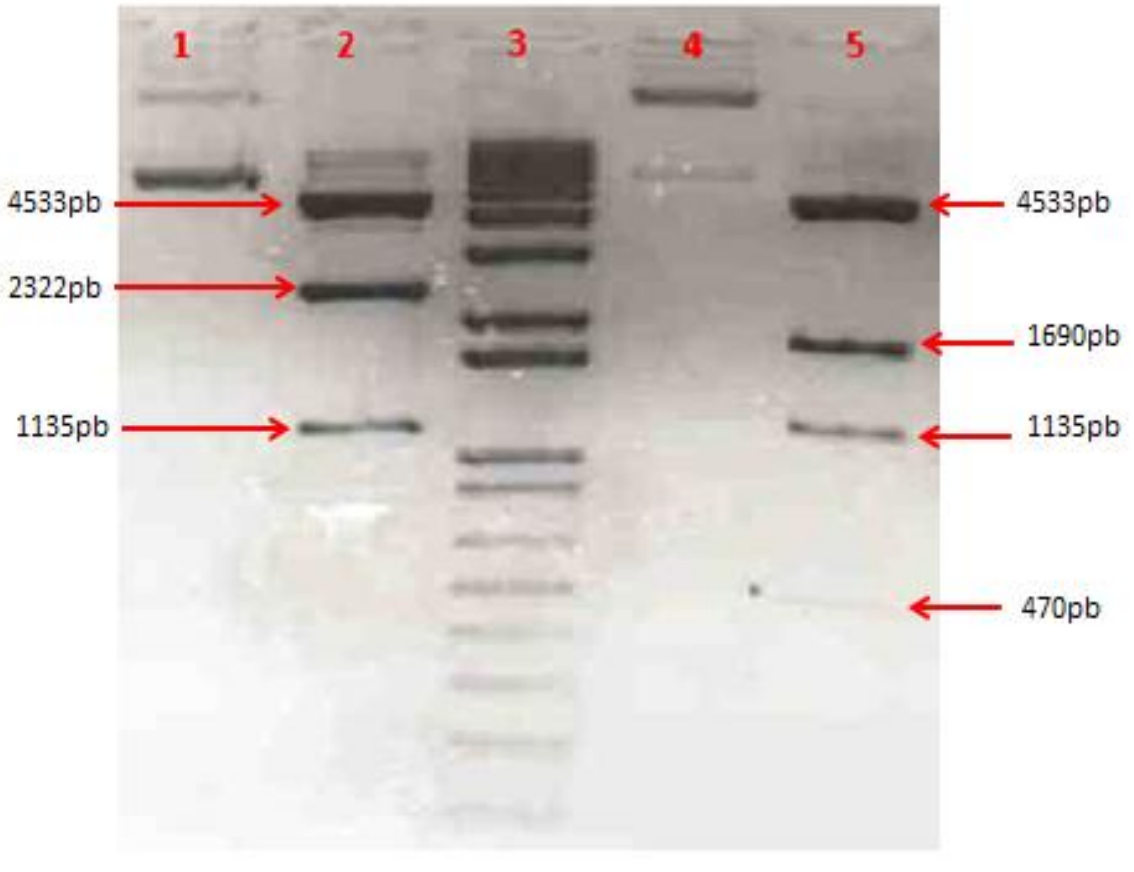

Figura 12. Desenho esquemático do vetor pCOMIRES $\triangle 600$ com a versão murina $s c F v 0$ e análise comparativa do perfil de restrição em gel de

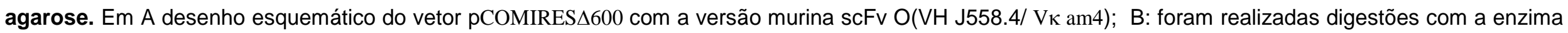
Pst I para diferenciar os clones recombinantes do plasmídio parental original (pCOMIRES $\triangle 600$ versão scFv anti-CD3). 1- pCOMIRES $\triangle 600$ versão scFv anti- CD3 intacto; 2: pCOMIRES $\triangle 600$ versão scFv anti- CD3 clivado com Pst I (bandas:4533,2322,1135); 3: 1kb DNA ladder Plus (Invitrogen); 4: pCOMIRES $\triangle 600$ scFv murino intacto; 5: pCOMIRES $\triangle 600$ scFv murino digerido com Pst I (bandas:4533, 1690, 1135, 470, 162). 

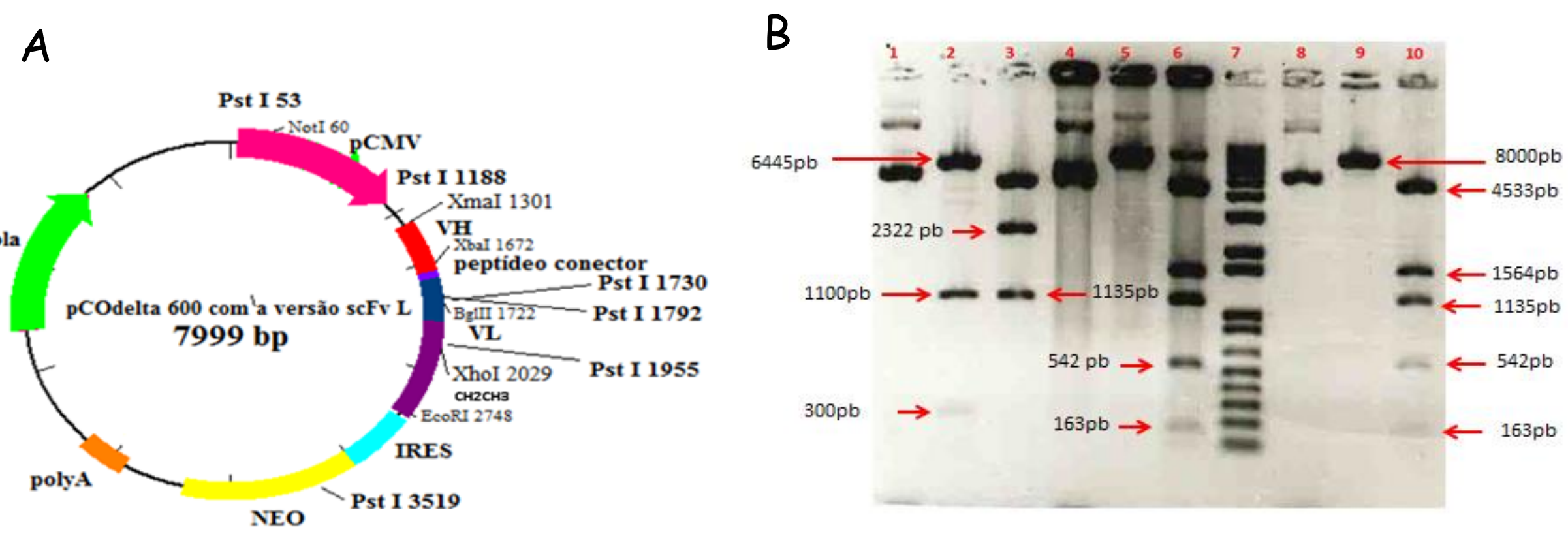

Figura 13. Desenho esquemático do vetor pCOMIRES $\triangle 600 \mathrm{com}$ a versão humanizada $s c F v ~ L$ e análise comparativa do perfil de restrição em gel de agarose. Em A desenho esquemático do vetor pCOMIRES $\triangle 600 \mathrm{com}$ a versão humanizada scFv L (humanVH1-46/ VkL1); B: foram realizadas digestões com as enzimas Kpn I e Pst I para diferenciar os clones recombinantes do plasmídio parental original (pCOMIRES $\triangle 600$ versão scFv anti- CD3). 1- pCOMIRES $\triangle 600$ anti-CD3 intacto; 2- pCOMIRES $\triangle 600$ anti-CD3 digerido com Kpn I (bandas: 6445, 1100, 300 pb); 3- pCOMIRES $\triangle 600$ anti-CD3 digerido com Pst I (bandas:4533,2322,1135 pb). Dois clones recombinantes foram analisados, sendo os poços 4 a 6 referentes ao clone 1, e 8 a 10, ao clone 2. Todos foram digeridos com Kpn I (banda única de 8000 pb, poços 5 e 9 ) e com Pst I (bandas:4533, 1564, 1135, 542, 163, 62pb poços 6 e 10). Os clones recombinantes intactos são mostrados nos poços 4 e 8.0 marcador de massa molecular 1kb DNA ladder Plus_Invitrogen está mostrado no poço 7. 
Após as análises do perfil de restrição dos clones recombinantes em comparação ao pCOMIRES $\Delta 600$ com scFv anti- CD3, foram feitas as análises de PCR. As condições padrões para estas análises estão descritas em materiais e métodos. O objetivo foi verificar se os primers desenhados amplificavam os domínios VH e VL das versões scFvs. O primeiro par de primers Xma I e Xba I amplifica os domínios VH, enquanto que o segundo par de primers Bgl Il e Xho I amplifica os domínios VL (Figura 16).

Como já descrito na Introdução, na humanização dos dois fragmentos scFvs das versões A e L, objetivou-se manter as CDRs murinas da molécula quimérica original. Logo, o desenho dos primers teve como base as CDRs 1 e 3 dos domínios VH e VL, uma vez que são idênticas nas três versões. A figura 14 mostra a estratégia para esta PCR, e a figura 15 mostra a análise em gel de agarose $1,5 \%$ do resultado da PCR das três versões.

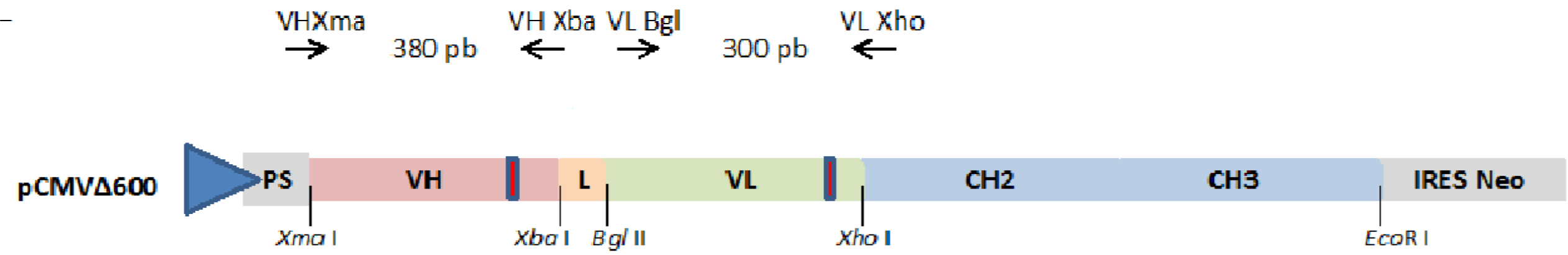

Figura 14: Desenho esquemático dos primers utilizados para a confirmação das clonagens por PCR. 


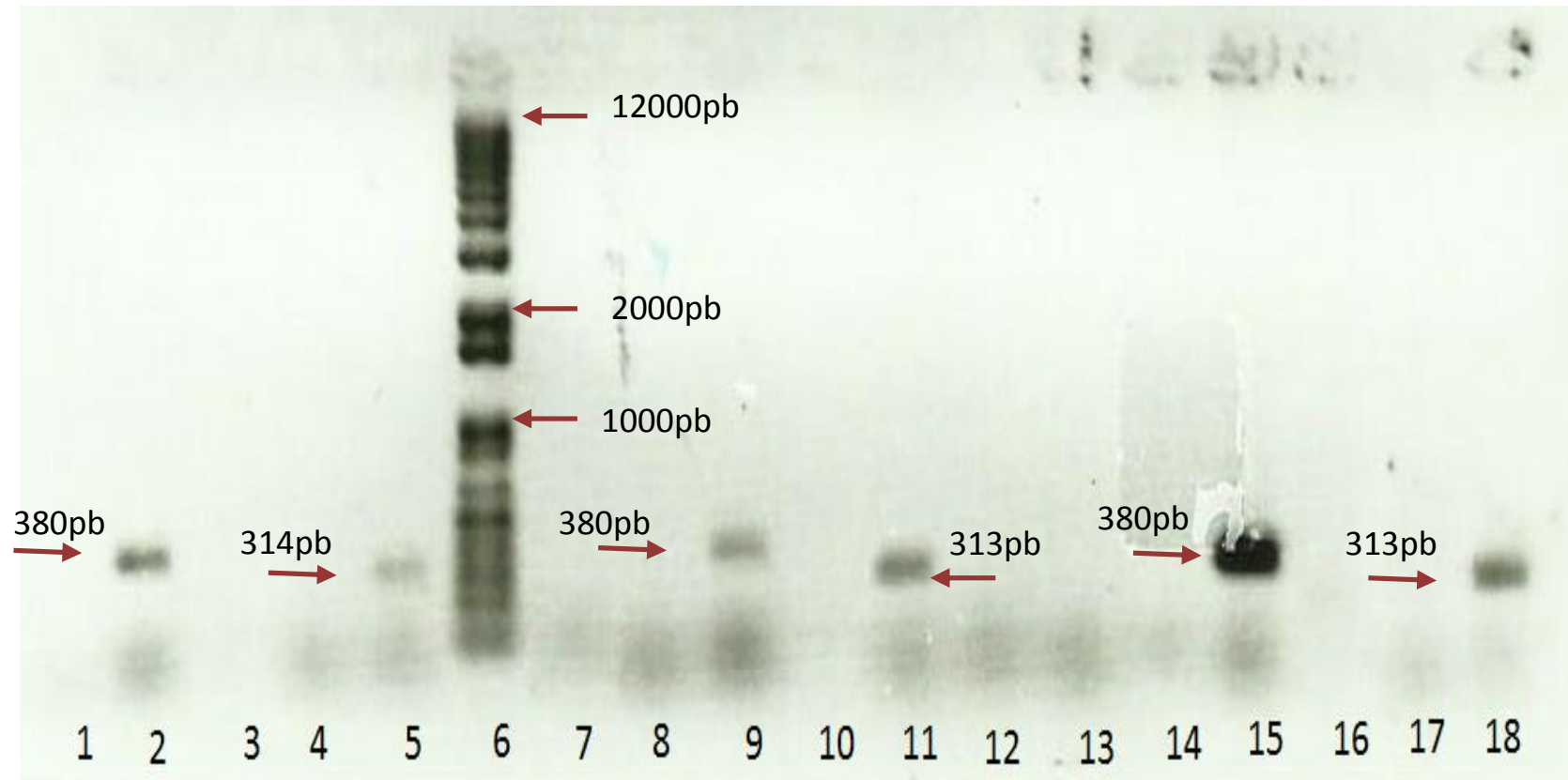

Figura 15: Análise em gel de agarose 1,5\% com o resultado da PCR das três construções. No poço no 2 a VH da versão $O$ com 380 pb e no poço 5 a VL da versão $O$ com 314 pb; no poço no 9 a VH da versão $A$ com 380 pb e no poço 11 a VL da versão $A$ com 313 pb; no poço no 15 a VH da versão $L$ com 380 pb e no poço 18 a VL da versão L com aproximadamente 300 pb. No poço no 6 o marcador $1 \mathrm{~kb}$ DNA ladder plus da Invitrogen.

\subsection{Obtenção de populações mistas de células CHO-K1 produtoras dos FvFcs recombinantes.}

Nesta etapa foram utilizadas células de ovário de hamster chinês versão K1 (CHO-K1), uma vez que, são consideradas um sistema de expressão heteróloga e produção eficiente para anticorpos (Gaillet et.al., 2010). Essas células epiteliais de morfologia fibroblastóide são aderentes e capazes de produzir os fragmentos FvFc com fidelidade em relação as modificações pós-traducionais, como por exemplo a glicosilação dessas proteínas (Gaillet et.al., 2010).

Como descrito em materiais e métodos as células $\mathrm{CHO}-\mathrm{K} 1$ foram transfectadas quando atingiram uma confluência na placa entre 50 a $60 \%$, essa confluência ocorria após 24 horas.

Estas células foram transfectadas na presença de 2ug de plasmídio com 
lipossomas (JetPEI). Para tanto, dividimos as placas em três grupos de acordo com a versão do plasmídio pCOMIRES $\triangle 600$ : placas $A$ foram transfectadas com o plasmídio pCOMIRES $\triangle 600$ versão A (humanVH1-46/VкA27), placas $\mathrm{O}$ com plasmídio pCOMIRES $\triangle 600$ versão $\mathrm{O}(\mathrm{VH}$ J558.4/Vкam4) e, placas $\mathrm{L}$ com o plasmídio pCOMIRES $\triangle 600$ versão L (humanVH1-46/VkL1).

Após 48 horas, as células transfectadas foram mantidas na presença do antibiótico geneticina para a seleção da população mista de células $\mathrm{CHO}-\mathrm{K} 1$ produtores dos FvFcs recombinantes. A concentração de geneticina que melhor se adequou para manter as células transfectadas foi $600 \mathrm{ug} / \mathrm{mL}$. Sendo que, nas primeiras 48 horas a pressão seletiva foi de $400 \mathrm{ug} / \mathrm{mL}$, depois as pressões seletivas foram de $600 \mathrm{ug} / \mathrm{mL}$. Pois, a produção das proteínas recombinantes foi extremamente baixa nas concentrações $500 \mathrm{ug} / \mathrm{mL}$ e $800 \mathrm{ug} / \mathrm{mL}$.

Embora,a obtenção de clones estáveis seja a mais adequada para atingir altos níveis de produção, ela requer mais tempo, decidiu-se trabalhar com a população mista de células $\mathrm{CHO}$ - K1 produtoras dos FvFcs recombinantes, segundo Silva 2008, esta estratégia é possível embora não seja a mais eficaz. Assim que as células sobreviveram e atingiram a confluência de $60 \%$, as células foram tripsinisadas e transferidas para garrafas de $15 \mathrm{~cm} 2$. O sobrenadante de cultura foi avaliado quanto á presença de FvFc por meio de imunodetecção ELISA

O método "ELISA sanduíche" foi utilizado para confirmar a produção dos FvFcs recombinantes. $\mathrm{O}$ anticorpo de Cabra anti-IgG humana $(\mathrm{H}+\mathrm{L})$ utilizado na sensibilização das placas e o anticorpo de Cabra anti-Fc humana conjugado com fosfatase alcalina, mostram a fusão dos scFvs aos domínios $\mathrm{CH} 2$ e $\mathrm{CH} 3$ clonados no vetor pCOMIRES $\triangle 600$, e que, também foi possível a expressão da molécula FvFc inteira. Os anticorpos utilizados e a metodologia estão descritos na seção de materiais e métodos.

Após esta etapa, antes das células serem transferidas para as garrafas de 75 $\mathrm{cm}^{2}$, foi feita a contagem de células viáveis produtoras dessas proteínas recombinantes, para cada construção: $L=18 \cdot 10^{5}, A=19 \cdot 10^{7}$, e $O=17 \cdot 10^{7}$.

Como a quantidade de células era suficiente para o crescimento e produção dos FvFcs recombinantes, passamos a reduzir a concentração do SFB de 10\% para 
$5 \%$ após $48 \mathrm{~h}$, depois de $5 \%$ para $2,5 \%$ após $48 \mathrm{~h}$ no meio de cultura, depois para $1,25 \%$ com low IgG após $48 \mathrm{~h}$ com. A utilização do soro fetal bovino em baixas concentrações no meio de cultura, se faz necessária para minimizar a contaminação com proteínas do soro fetal bovino, melhorando a purificação das proteínas recombinantes. Assim como foi necessário retirar a geneticina do meio de cultura, para diminuir o stress da célula.

Essa diminuição gradativa é relevante não só para adaptação das células que necessitam de SBF para aderirem, mas também para que o promotor CMV não se torne responsivo a quantidades reduzidas de SFB e passe a regular negativamente o processo de transcrição (Silva et.al., 2009). Logo, a cada 48h o sobrenadante era recolhido para análises por meio de imunodetecção ELISA, para as avaliações quantitativas do sobrenadante com low IgG em relação a produção dos FvFcs recombinantes. 
Tabela 4: Quantificação estimada do total de proteínas recombinantes em $\mathrm{ng} / \mathrm{mL}$, referente ao acumulo de sobrenadante de cada garrafa da versão 0 .

\begin{tabular}{|c|c|c|c|c|}
\hline Garrafas & $\begin{array}{c}\text { Média de Produção } \\
\text { dos FvFcs em ng/mL }\end{array}$ & $\begin{array}{c}\text { Total em } \\
\mathrm{mL}\end{array}$ & Semanas & $\begin{array}{c}\text { Quantificação } \\
\text { Total }\end{array}$ \\
\hline O1 & $11,22 \mathrm{ng} / \mathrm{mL}^{ \pm} 0,019$ & 45 & 3 & $504,9 \mathrm{ng} / \mathrm{mL}$ \\
\hline O2 & $7,01 \mathrm{ng} / \mathrm{mL}^{ \pm} 0,015$ & 90 & 6 & $630,9 \mathrm{ng} / \mathrm{mL}$ \\
\hline O3 & $3,59 \mathrm{ng} / \mathrm{mL}^{ \pm} 0,008$ & 150 & 10 & $538,5 \mathrm{ng} / \mathrm{mL}$ \\
\hline
\end{tabular}

Tabela 5: Quantificação estimada do total de proteínas recombinantes em $\mathrm{ng} / \mathrm{mL}$, referente ao acumulo de sobrenadante de cada garrafa da versão $A$.

\begin{tabular}{|c|c|c|c|c|}
\hline Garrafas & $\begin{array}{c}\text { Média de Produção } \\
\text { dos FvFcs em } \mathrm{ng} / \mathrm{mL}\end{array}$ & $\begin{array}{c}\text { Total em } \\
\mathrm{mL}\end{array}$ & Semanas & $\begin{array}{c}\text { Quantificação } \\
\text { Total }\end{array}$ \\
\hline A1 & $2,01 \mathrm{ng} / \mathrm{mL}^{ \pm} 0,003$ & 150 & 10 & $301,5 \mathrm{ng} / \mathrm{mL}$ \\
\hline A2 & $2,2 \mathrm{ng} / \mathrm{mL}^{ \pm} 0,012$ & 120 & 8 & $264 \mathrm{ng} / \mathrm{mL}$ \\
\hline A3 & $2,9 \mathrm{ng} / \mathrm{mL}^{ \pm} 0,012$ & 135 & 9 & $391,5 \mathrm{ng} / \mathrm{mL}$ \\
\hline A4 & $5,53 \mathrm{ng} / \mathrm{mL}^{ \pm} 0,025$ & 45 & 3 & $249 \mathrm{ng} / \mathrm{mL}$ \\
\hline A5 & $6,27 \mathrm{ng} / \mathrm{mL}^{ \pm} 0,006$ & 75 & 5 & $470,25 \mathrm{ng} / \mathrm{mL}$ \\
\hline A6 & $4,24 \mathrm{ng} / \mathrm{mL}^{ \pm} 0,020$ & 90 & 6 & $381,6 \mathrm{ng} / \mathrm{mL}$ \\
\hline
\end{tabular}


Tabela 6: Quantificação estimada do total de proteínas recombinantes em $\mathrm{ng} / \mathrm{mL}$, referente ao acumulo de sobrenadante de cada garrafa da versão $\mathrm{L}$.

\begin{tabular}{|c|c|c|c|c|}
\hline Garrafas & $\begin{array}{c}\text { Média de Produção } \\
\text { dos FvFcs em ng/mL }\end{array}$ & $\begin{array}{c}\text { Total em } \\
\mathrm{mL}\end{array}$ & Semanas & $\begin{array}{c}\text { Quantificação } \\
\text { Total }\end{array}$ \\
\hline $\mathrm{L} 1$ & $15,59 \mathrm{ng} / \mathrm{mL}^{ \pm} 0,020$ & 45 & 3 & $701,55 \mathrm{ng} / \mathrm{mL}$ \\
\hline $\mathrm{L} 2$ & $11,76 \mathrm{ng} / \mathrm{mL}^{ \pm} 0,007$ & 60 & 4 & $705,6 \mathrm{ng} / \mathrm{mL}$ \\
\hline $\mathrm{L} 3$ & $7,06 \mathrm{ng} / \mathrm{mL}^{ \pm} 0,014$ & 75 & 5 & $529,5 \mathrm{ng} / \mathrm{mL}$ \\
\hline
\end{tabular}

Estes sobrenadantes eram congelados semanalmente com inibidores de protease e posteriormente foram purificados.

Diante dos resultados apresentados, a melhor alternativa foi manter a pressão seletiva das células sempre que a produção caísse, e retirar esta pressão seletiva sempre que a quantidade de células aderidas com a morfologia fibroblastóide fosse muito reduzida e não houvesse mais produção das proteínas recombinantes. Com isso, foi feito o acúmulo de muito sobrenadante, durante algumas semanas.

As tabelas mostram a quantidade em $\mathrm{mL}$ que foi acumulada de cada garrafa e 0 número de semanas (uma vez que a troca de meio era realizada semanalmente), foi estimado a quantificação total em $\mathrm{ng} / \mathrm{mL}$ referente ao acumulo de sobrenadante de cada garrafa.

\subsection{Produção e purificação das proteínas recombinantes}

O sobrenadante de cultura, das proteínas recombinantes que foram produzidas a partir das culturas de populações mistas de células $\mathrm{CHO}-\mathrm{K} 1$ transfectadas obtidas como descrito no item anterior, foram submetidos a uma cromatografia de afinidade, utilizando a coluna HITRAP protein A HP da GE, uma vez que a proteína $A$ tem afinidade a Fc humana. Após a purificação as frações coletadas da coluna foram quantificadas por ELISA. Depois foram analisadas quanto ao grau de pureza destes fragmentos de 
interesse por meio de SDS-PAGE e posteriormente Western-Blot. Após a purificação das proteínas recombinantes a quantidade estimada para cada versão foi de: $596 \mathrm{ng}$ para versão A, 906 ng para versão $O$, e 1.273 ng para versão L.

Como podemos perceber o grande acúmulo de sobrenadante com baixas concentrações de proteínas, interfere na quantidade total de proteínas após a purificação, porque ocorreu uma perda substâncial durante este processo. Embora a perda de proteínas recombinantes durante este processo foi baixa.

Após a purificação, os sobrenadantes foram concentrados utilizando a membrana de celulose Centricon da Millipore. Na construção $L$ obtivemos a maior produção e concentração enquanto que na versão A não foi possível obter a mesma proporção após a purificação dos FvFcs recombinantes.

No caso, a proteína A produzida pelo Staphylococcus aureus tem alta afinidade a fração Fc da IgG 1 da imunoglobulina humana. Logo, o princípio desta técnica contribuiu muito para uma boa purificação. A figura 16 mostra o gel SDS- PAGE de poliacrilamida desnaturante com coloração prata e a figura 17 o gel Western Blot, os fragmentos FvFcs possuem $55 \mathrm{kDa}$. 


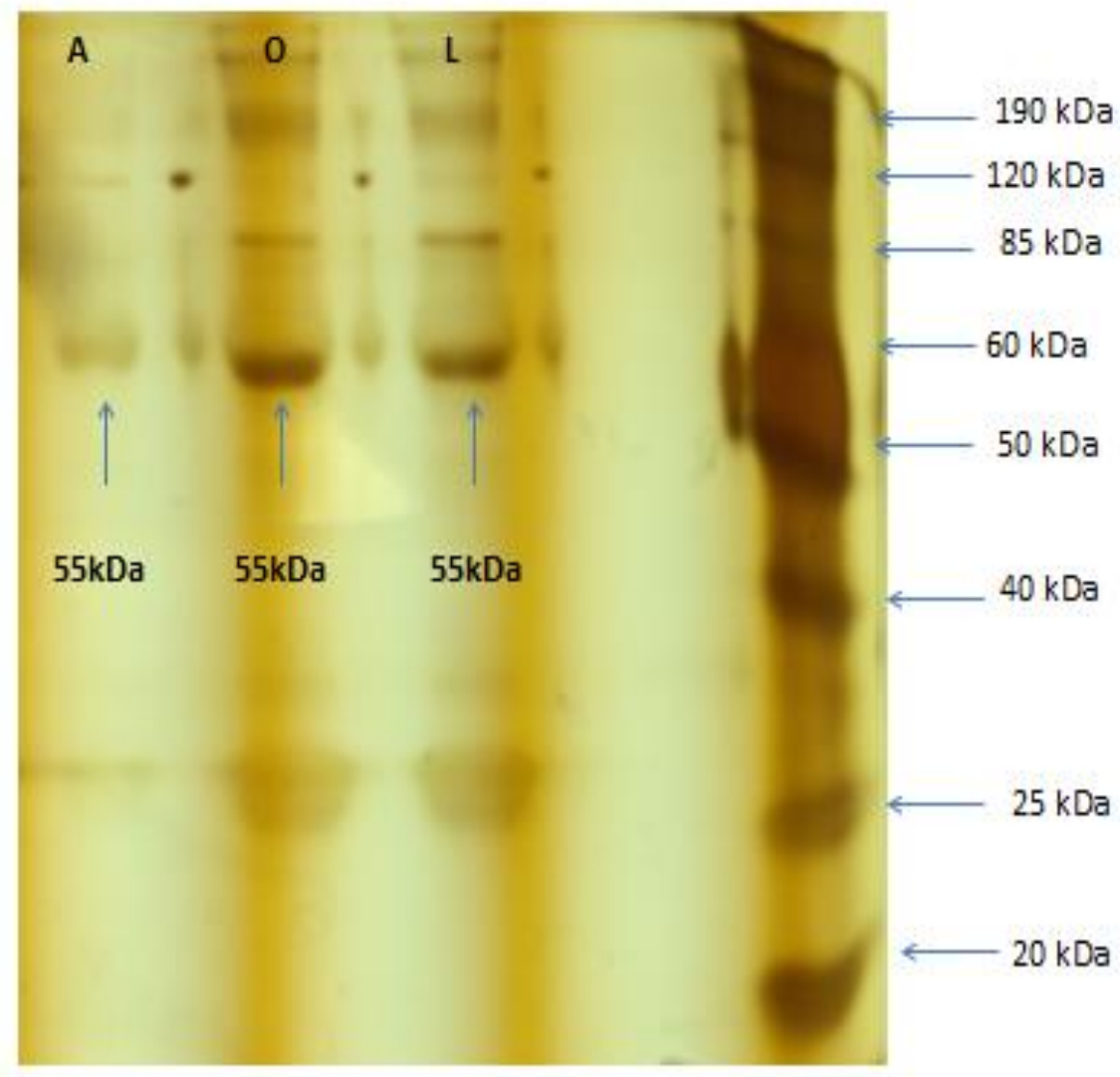

Figura 16 Gel SDS-PAGE mostrando as três construções, após os processos de purificação. Os fragmentos FvFcs possuem $55 \mathrm{kDa}$, respectivamente $\mathrm{A}, \mathrm{O}$ e $\mathrm{L}$. Ao lado o marcador de proteínas da Invitrogen BenchMark pre-stained. 


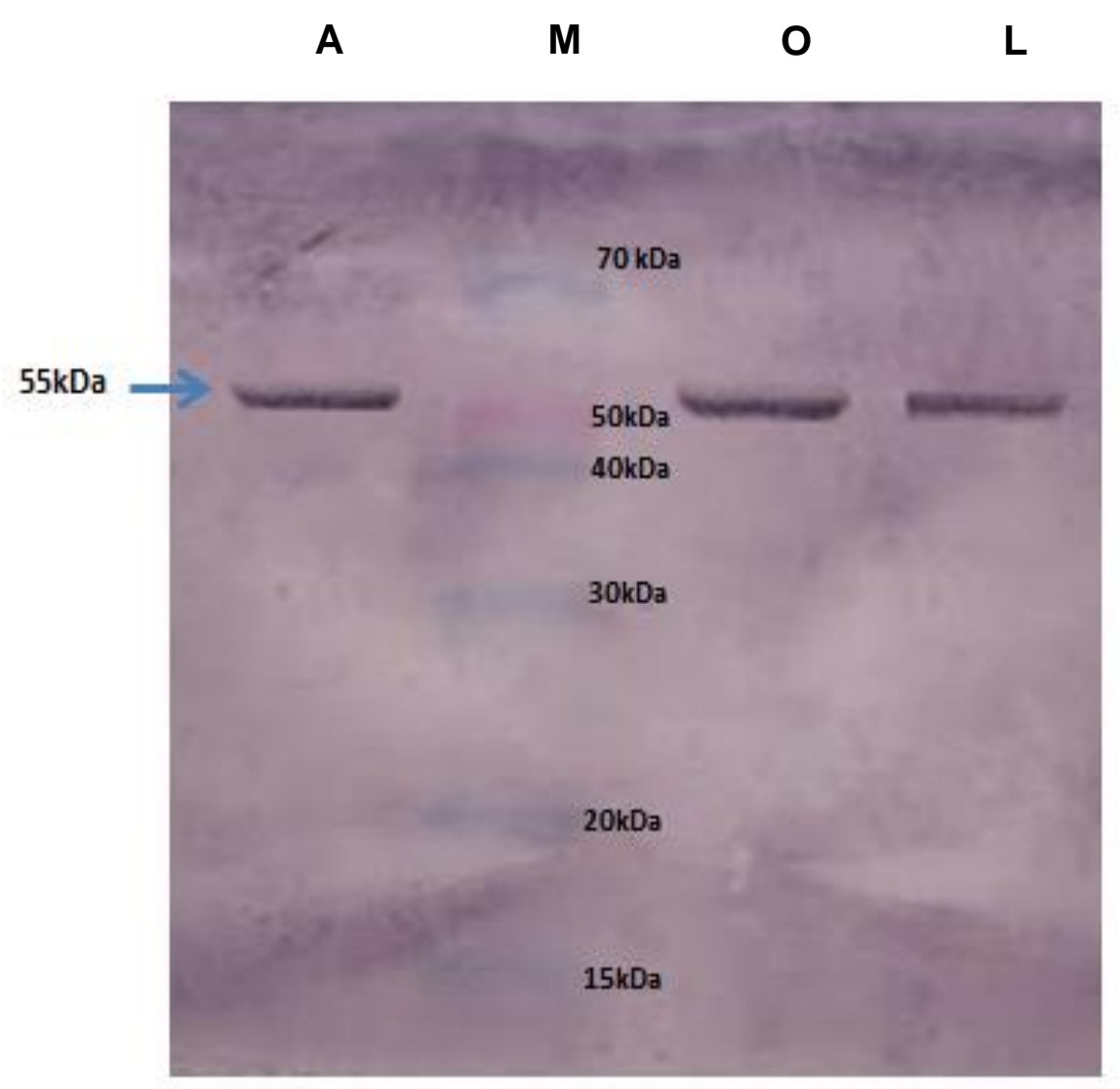

Figura 17 Análise por Western Blot dos fragmentos FvFcs $A, O$ e $L$, após os processos de purificação. Os fragmentos FvFcs $A$, O e L, possuem $55 \mathrm{kDa}$. O M representa o marcador de proteínas Nexus Pointer Mid Range Dual Color da Bionexus.

Os resultados demonstram que os três plasmídios podem promover a expressão das proteínas recombinantes em células CHO- K1 e, é possível produzir essas proteínas trabalhando com populações mistas destas células.

Com esses resultados é possível concluir que o vetor influenciou positivamente no processo de produção das proteínas recombinantes. Foi demonstrado por Quilici e colaboradores (2013), que a versão truncada $\Delta 600$ do Intron A presente na posição downstream do promotor CMV deste vetor de expressão, pode melhorar a expressão heteróloga de fragmentos de anticorpos humanizados, uma vez que, este vetor quando utilizado na transfecção de células CHO- K1 e HepG2 aumentou a expressão gênica do gene repórter da Luciferase (dado também demonstrado por qrPCR: aumento dos níveis de mRNA) (Quilici, et.al. 
2013). Logo, o pCOMIRES $\triangle 600$ é uma ótima alternativa para produção destas proteínas recombinantes.

Além do desempenho do vetor, as condições da cultura são extremamente relevantes para que as células $\mathrm{CHO}-\mathrm{K} 1$ produzam as proteínas recombinantes. Segundo Kim e colaboradores (2012), o acúmulo de amônia e lactato durante a cultura de células $\mathrm{CHO}$ é capaz de afetar negativamente o crescimento celular e a qualidade do produto. Estes dois produtos de lixo tóxico são gerados a partir de fontes de energia, tais como glutamina e glicose. Sendo assim, é preciso que os meios de cultura não contenham excesso desses nutrientes e que, as trocas do meio sejam pelo menos semanais (Kim et.al., 2012).

Segundo Omasa e colaboradores (2010), as células CHO necessitam de condições específicas para produzirem glicoproteínas recombinantes de forma fidedigna em relação aos processos pós traducionais, principalmente em relação a glicosilação. A glicosilação é considerada o processo pós traducional mais longo, diversos fatores podem interferir neste processo, resultando em impactos significativos na estrutura da molécula e na sua atividade biológica. Omasa e colaboradores descrevem que $\mathrm{o}$ teor de nutrientes, $\mathrm{pH}$, temperatura, e as concentrações de oxigênio dissolvido ou de amônia podem ter um impacto significativo sobre a distribuição das estruturas de glicano. Além das condições ambientais e nutricionais da cultura de células $\mathrm{CHO}$, a taxa específica de crescimento celular também pode afetar as estruturas de glicano (Omasa et.al., 2010).

$\mathrm{Na}$ literatura são descritos vários fatores que podem melhorar os níveis de expressão destas proteínas, recentemente um outro trabalho do grupo, desenvolvido por Gullis e colaboradores (2014), propõe a solução para o problema do rápido acumulo na produção de proteínas recombinantes e a quantidade de células viáveis. Os resultados deste trabalho mostram que a proteína XBP-1, relacionada com apoptose celular, pode ser downregulada por meio da co- transfecção com o plasmídio do sistema T- Rex (Invitrogen). Este processo também associa a produção de proteínas recombinantes a temperatura mais baixa $30 \stackrel{\circ}{\circ}$. As células transfectadas eram CHO- K1 aderentes, porém o trabalho não foi desenvolvido com a população mista de células e sim com clones estáveis, o vetor era similar ao que foi utilizado neste trabalho, o pCOMIRES, (sem a deleção de 600 pb no intron A). Pode ser que 
esse processo seja reprodutível para população de células mistas, e que o vetor pCOMIRES $\triangle 600$ possa melhorar a produção dos FvFcs recombinantes propondo estas condições (Gullis et.al., 2014).

Em 2010, Serpieri e colaboradores (2010), compararam o processo de produção de uma IgG anti-CD3 completa com o processo de produção de dois fragmentos FvFcs da mesma molécula, um dos resultados apresentados foi que não houveram diferenças significativas nos níveis de produção destas construções. Sendo assim, seria muito difícil que houvesse diferenças entre a produção do rituximabe e as versões FvFcs (Serpieri et.al., 2010).

Segundo Datta e colaboradores (2013), é extremamente relevante clonar o gene de interesse num vetor de expressão adequado e realizar a transfecção e a otimização da integração do transgene no genoma do hospedeiro, para uma produção em larga escala da proteína recombinante. Os resultados aqui apresentados mostram esta proposta, logo podemos propor a possibilidade de se produzir essas proteínas recombinantes em larga escala, utilizando clones estáveis ou linhagens de células em suspensão (Datta et.al., 2013). 
Conclusão e Perspectivas 
Pode-se concluir que é possível expressar e produzir fragmentos FvFcs antiCD20 humanos, com populações mistas de células $\mathrm{CHO}-\mathrm{K} 1$, utilizando o vetor de expressão em células de mamíferos pCOMIRES $\triangle 600$. Este vetor possibilitou 0 processo de transfecção transiente das células e também a fusão gênica das versões scFvs aos domínios $\mathrm{CH} 2$ e $\mathrm{CH} 3$ de uma IgG humana. Uma vez que, os fragmentos mostrados no gel SDS-PAGE e no Western-Blot, correspondem a $55 \mathrm{kDa}$.

Recentemente, foi determinada a capacidade de ligação das três construções por meio de citometria de fluxo, utilizando células RAJl (células que possuem o antígeno CD20 humano). As três versões FvFcs estabelecem ligações com o antígeno CD20 humano. Logo, podemos concluir o sucesso da construção e expressão dos fragmentos FvFcs anti-CD20 humanos e propor a obtenção de clones estáveis ou produção com linhagens de células em suspensão, para obtenção destas proteínas em larga escala utilizando as três construções com o plasmídio pCOMIRES $\triangle 600$. A figura 18 mostra uma análise destes resultados.

Com estes resultados é possível propor, avaliações das proteínas recombinantes produzidas quanto a estabilidade conformacional, e se podem exercer os mesmos mecanismos fisiológicos que o rituximabe. Demonstrando com isso que as CDRs murinas permaneceram no arcabouço das regiões scFvs e que a estrutura Fc humana é capaz de estabilizar o fragmento FvFc e recrutar as atividades efetoras: ADCC, CDC, ADP e PCD. 


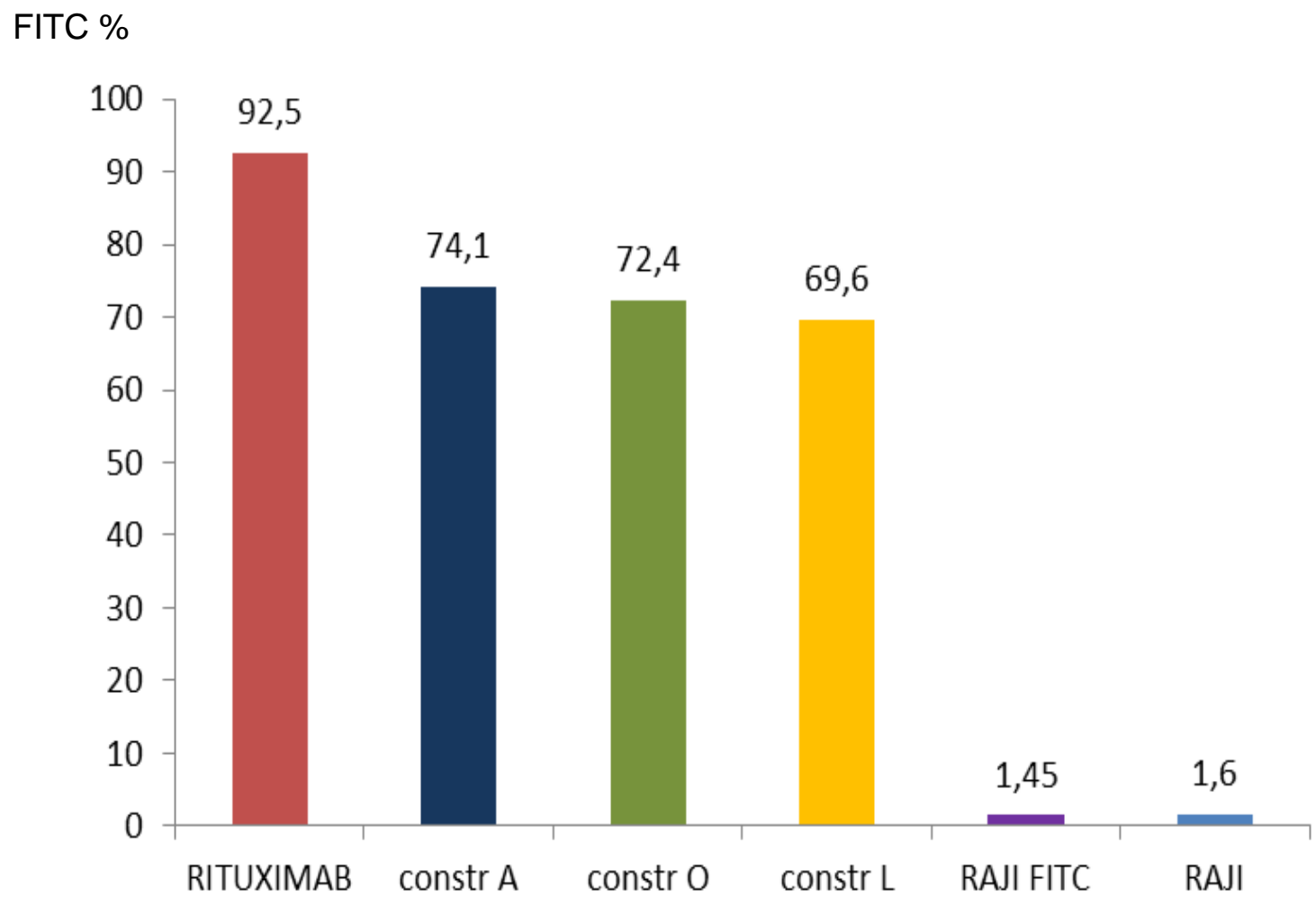

Figura 18 Capacidade de ligação á molécula CD20 das três construções FvFcs em comparação com o anticorpo rituximabe.

Esses dados sugerem que a capacidade de ligação das três construções é considerável com a atividade ligante do rituximabe. Pode-se observar que os FvFcs humanizados (construções $A$ e L), possuem uma capacidade de ligação á molécula CD20 comparável com a capacidade de ligação da versão FvFc murina similar ao anticorpo quimérico rituximabe (construção 0 ). 
Referências Bibliográficas 
Andrade E.V., Albuquerque, F.C., Moraes, L.M., Brígido, M.M., Santos-Silva MA., Singlechain FV with Fc fragment of the human IgG1 tag: contruction, Pichia pastoris expression and antigen bilding characterization. J. Biochen, v.128, n.6, p. 891-895, 2000.

Andrade E.V., Albuquerque F.C., Moraes L.M., Brígido M.M., Santos- Silva M.A., Thermodynamic basis for antibody biding to Z- DNA: comparison of a monoclonal antibody and its recombinant derivates, Biochim Biophys Acta, vol. 128, n.6, p. 891-895, 2005.

Amoroso, A., Hafsi, S., Militello, L., Russo, A.E., Soua, Z., Mazzarino, M.C., Stivala, F., Libra, M., Understanding rituximab function and resistance: implications for tailored therapy, Front Biosci., v16, p770-782, 2011.

Azevedo, M.O., Felipe, M.S.S., Brígido, M.M., Maranhão, A.Q., De-Souza M.T., Técnicas Básicas em Biologia Molecular, UnB, 2003.

Bacorro, E.A., Tehrani, R., Stiff-person syndrome: persistent elevation of glutamic acid decarboxylase antibodies despite successful treatment with rituximab., J. Clin Rheumatol, v.16, n.5, p. 237-239, 2010.

Bassing C.H., Swart W., Alt F.W., The mechanism and regulation of chromosomal V(D)J recombination Cell, vol. 109, p. S45-S55, 2002.

Binder, M., Otto, F., Mertelsmann, R., Veelken, H., Trepel, M., (2005). The epitope recognized by rituximab. Blood, v108, p1975-1978, 2006.

Bornstein, G.G, Quéva, C., Tabrizi, M., van Abbema, A., Chavez, C., Wang, P., Foord,O., Ahluwalia, K., Laing, N., Raja, S., Wen, S., Green, L.L., Yang, X., Webster, C., Stewart, R., Blakey, D., Development of a new fully human anti- CD20 monoclonal antibody for the treatment of $B$-cell malignencies. Invest New Drugs, v.28, p.561-574, 2009.

Brodsky R.A., How I treat paroxysmal nocturnal hemoglobinuria, Blood, v.25, June 25, p. 113- 139, 2009.

Caldas, C., Coelho, V.P., Ridgen, D.J., Neschich, G., Moro, A.M., Brígido, M.M., Design and synthesis of germline-based hemi-humanized single-chain FV against the CD18 surface antigen. Protein Eng. v.13, p.353-360, 2000. 
Costa, P. Caracterização da Atividade Ligante de Domínios Variáveis Humanizados de um Anticorpo Anti-CD3 Humano. Universidade de Brasília, 2004.

Campos-da-Paz, M.; Costa, C. S.; Quilici, L. S.; Simões, I. D.; Kyaw, C. M.; Maranhão, A. Q. e Brígido, M. M. Production of Recombinant Human Factor VIII in Different Cell Lines and the Effect of Human XBP1 Co-Expression. Mol Biotechnol., 2008.

Datta P., Linhardt R.J., Sharfstein S.T., An 'Omics Approach Towards CHO Cell Engineering, Biotechnol. Bioeng. , vol. 110, p. 1255-1271, 2013.

Ernst, J.A., Li H., Kim, H.S., Nakamura, G.R., Yansura, D.G., Vandlen, R.L, Isolation and characterization of the B-Cell marker CD20. Biochemistry, v.22, p.44-46, 2005.

Fang, H., Miao, Q., Zhang, S., Cheng, X., Xiong, D., Zhen, Y., Antitumor effects of an engineered and energized fusion protein consisting of an anti-CD2O scFv fragment and lidamycin, Sci China Life Sci., v54, n3, p255-262, 2011.

Frank M.M., Austen K.F., Claman H.N., Samter`s Immunologic Disseases, 5th ed., Unanue ER, 1995.

Fonseca, A.S.D., Construção e expressão de duas versões humanizadas scFv de duas versões humanizadas anti-CD3, Dissertação de Mestrado, Departamento de Biologia Celular, Universidade de Brasília, Brasília, 2000.

Furger, A.; O'Sullivan, J. M.; Binnie, A.; Lee, B. A. e Proudfoot, N. J. Promoter proximal splice sites enhance transcription. Genes and Development, v.16, p.2792-99, 2002.

Gellert M., $V(D) J$ recombination: RAG proteins, repair factors, and regulation. Annual Review of Biochemistry, vol. 71, p. 101-132, 2002.

Giddings, G.; Allison, G.; Brooks, D.; Carter, A. Transgenic plants as factories for biopharmaceuticals. Nature Biotechnology, v. 18, p. 1151-1155, 2000.

Gibson T.B., Ranganathan A., Grothey A., Randomized Phase III Trial Results of Panitumumab, a Fully Human Anti-Epidermal Growth Factor Receptor Monoclonal 
Antibody, in Metastatic Colorectal Cancer, Clinical Colorectal Cancer, vol. 6, p. 29-31, 2006.

Gullis G., Simi R.C.K., Toledo R.R., Maranhão Q.A., Brígido M.M., Optimização of heterelogus protein prodution in Chinese hamster ovary cells under overexpression of spliced from of humam X-box biding protein.,BMC Biotechnology, vol 256, p. 14-26, 2014.

Houdebine, L.M.; Attal, J. Internal ribosome entry sites (IRESs): reality and use. Transgenic RES, Res, v.8, n.157. 1999.

Holliger P, Hudson PJ., Engineered antibody fragments and the rise of single domains, Nat Biotechnol, v.23, n.9, p.1126-1136, 2005.

Honjo T., Kinoshita K., Muramatsu M., Molecular mechanism of class switch recombination: linkage with somatic hypermutation. Annual Review of Immunology, vol 20, p. 165-196, 2002.

Jayapal, K.P.; Wlaschin, K.F.; Hu, W.S.; Yap, M.G. Recombinant protein therapeutics from CHO cells - 20 years and couting. Chem En Progr. 103: 40-47, 2007.

Jens Nielsen. Production of biopharmaceutical proteins by yeast: Advances through metabolic engineering. Bioengineered, v. 4 (4), pp. 1 - 5, 2013.

Jung D., Unraveling $V(D) J$ recombination: insights into gene regulation. Cell, vol. 116, $p$. 299-311, 2004.

Krauss J. Recombinant Antibodies for the Diagnosis and Treatment of Cancer, Molecular Biotechnology, vol 25: 1-17, 2003.

Keating, G.M., Rituximab: a review of its use in chronic lymphocytic leukaemia, low-grade or follicular lymphoma and diffuse large B-cell lymphoma, Drugs, v.70, p.1445-1476, 2010. 
Klein C.,Lammens A.,Schäfer W., Georges G., Schwaiger M., E. Mössner,Hopfner K.P., Umaña P.,Niederfellner G., Epitope interactions of monoclonal antibodies targeting CD20 and their relationship to functional properties, Landes Bioscience, v.5, p. 22-33, 2013.

Kim L.Y., Kim Y.G., Lee M.G., CHO cells in biotechnology for production of recombinant proteins: current state and further potential, Microbiol Biotechnol , vol. 93, p.917-930, 2012.

Kotani, T., Takeuchi, T., Kawasaki, Y., Hirano, S., Kagitani, M., Tabushi, M., Makino, S., Hanafusa, T., Successful treatment of cold agglutinin disease with anti-CD20 antibody (rituximab) in a patient with systemic lupus erythematosus. Lupus, v.15, p.683-685, 2006.

Kohler G., Milstein C., Continuous culture of fused cells secreting antibody of predetermined specificity. Nature, v.256:, p. 495-497, 1975.

Le Hir, H.; Nott, A. e Moore M.J. How introns influence and enhance eukaryotic gene expression. Trends in Biochem. Sci, p. 215-220. 2003.

Li, J.; Menzel, C.; Meier, D.; Zhang, C.; Dübel, S. e Jostock, T. A comparative study of different vector designs for the mammalian expression of recombinant $\lg G$ antibodies. Blood, JIM, v. 318, p.113-124. 2007.

Lim, S.H., Beers, S.A., French, R.R., Johnson P.W., Glennie, M.J., Cragg, M.S., AntiCD20 monoclonal antibodies: Historical and future perspectives, Haematologica, v.10, p.10-42, 2010.

Liu, K.; Sandgren, E. P.; Pamiter, R. D. e Stein, A. Rat growth hormone gene introns stimulate nucleossome alignment in vitro and in transgenic mice. PNAS, v.92, p.7724:28. 1995.

Litman G.W., Rast J.P., Fugmann S.D.. The origins of vertebrate adaptative immunity. Nature Reviews Immunology, v. 10, p. 543-553, 2010. 
Maranhão, A.Q., Brígido, M.M., Anticorpos humanizados, Biotecnologia Ciência \& Desenvolvimento, v.23, p. 38-43, 2001

Mariati, N.Y.K.; Chao, S.H.; Yap, M.G.S.; Yang, Y. Evaluating regulatory elements of human cytomegalovirus major immediate early gene for enhancing transgene expression levels in CHO-K1 and HEK293 cells. Journal of Biotecnol. 147:160-3, 2010.

Marszal E., Fowler E., Workshop on Predictive Science of the Immunogenicity Aspects of Particles in biopharmaceutical products, Jhournal of Pharmaceutical Sciences, v.101, n.10, p. 3555-3559, 2012.

Mattanovich, Diethard; Branduardi, Paola; Dato, Laura; Gasser, Brigitte; Sauer, Michael and Porro, Danilo. Recombinant Protein Production in Yeasts. Recombinant Gene Expression: Methods in Molecular Biology ,Volume 824, pp 329-358, 2012.

Mayes S., Brown N., Illidge T.M., New antibody drug treatments for lymphoma. Expert Opin Biol Ther., v11, n5, p623-40, 2011.

Measi P.J., Adalimumab: an anti-TNF agent for the treatment of psoriatic arthritis, Expert Opin Biol Ther, vol. 5, p. 1491-1504, 2005.

McLean, G. R.; Nakouzi, A.; Casadeval, A.; Green, N.S. Human and Murine immunoglobulin expression vector cassettes. Molecular Immunology. 37(14): 837-45, 2000.

Montraveta A., Torrent, Mónica X.S., Guerra L., Rosich L., Galán1 P.L., Salaverria I., Beà S., Kalko S.G., Frias M., Campàs C., Roué G., Colomer D., Synergistic anti-tumor activity of acadesine (AICAR) in combination with the anti-CD20 monoclonal antibody rituximab in in vivo and in vitro models of mantle cell lymphoma, V.5, 726-739, Impact Journals/ Oncotarget, 2014.

Niiro H., Clark E.A., Regulation of B - cell fate by antigen- receptor signals. Nature Reviews Immunology, vol 2, p 945-956, 2002.

Oflazoglu, E., Audoly, L., Evolution of anti CD20 monoclonal antibody therapeutics in oncology, Lande Biocience, v.12, p.14-19, 2010. 
Ohyama, T. Intrinsic DNA bends: an organizer of local chromatin structure for transcription. Bioessays, 23:708-715, 2001.

Omasa T., Onitsuka M., Wook-Dong K., Cell Engineering and Cultivation of Chinese Hamster Ovary (CHO) Cells, Current Pharmaceutical Biotechnology, vol. 11, p. 233-240, 2010.

Papavasiliou F.N., Shatz D.G., Somatic hypermutation of immunoglobulin genes: merging mechanisms for genetic diversity. Cell, vol. 109, p. S35- S44, 2002.

Pateinakis P., Pyrpasopoulou A., CD20+ B Cell Depletion in Systemic Autoimmune Diseases: Common Mechanism of Inhibition or Disease-Specific Effect on Humoral Immunity?, Hindawi, v2014, p.5, 2014

Pievani, A., Belussi, C., Klein, C., Rambaldi, A., Golay, J., Introna, M., Enhanced killing of human B-cell lymphoma targets by combined use of cytokine-induced killer cell (CIK) cultures and anti-CD20 antibodies. Blood., v117, p510-518, 2011.

Pinto M. C., Carrasco G.M., Ruiz V.V., Cole T.A., Guarneros M.M., Poblano J.C.S., Said E.P., Lemarroy A.A., Suarez J.F.L., Lara V.L., Alvarez G.R., Leyva R.J., Colomb A.L., The impact of glucocorticoids and anti-cd20 therapy on cervical human papillomavirus infection risk in women with systemic lupus erythematosus, Clinical Science, v.12, p. 1475-1480, 2013.

Pescovitz, M.D., Greenbaum, C.J., Krause-Steinrauf, H., Becker, D.J., Gitelman, S.E., Goland, R., Gottlieb, P.A., Marks, J.B., McGee, P.F., Moran, A.M., Raskin, P., Rodriguez, H., Schatz, D.A., Wherrett, D., Wilson, D.M., Lachin, J.M., Skyler, J.S., Rituximab, Blymphocyte depletion, and preservation of beta-cell function, ․․ Engl J. Med., v.26, p. 21432152, 2009.

Presta L.G., Enegenering of therapeutic antibodies to minimize immunogeniticity and optimize function, Adv Drug Deliv Review, vol. 58, p. 640-656, 2006. 
Quilici, L.S. Caracterização de elementos moduladores da expressão gênica em células de mamífero: estudo do Intron A do gene Precoce Imediato de Citomegalovírus. Tese de Doutorado. Departamento de Biologia Celular, Universidade de Brasília, Brasília, 2013.

Quilici, L.S. Estudo de elementos moduladores da expressão gênica em diferentes linhagens de células de mamífero. Dissertação de Mestrado. Departamento de Biologia Celular, Universidade de Brasília, Brasília, 2008.

Quilici L.S., Silva-Pereira I., Andrade A.C., Albuquerque F.C., Brigido M.M., Maranhão A.Q., A minimal cytomegalovirus intron $A$ variant can improve transgene expression in different mammalian cell lines, Biotechnol Lett, vol.35, p.21-27, 2013.

Robak T., Robak E., New anti-CD20 monoclonal antibodies for the treatment of B-cell lymphoid malignancies, Bio Drugs v.25, p.13-25, 2011.

Ruggiero, L.A. Clonagem de anticorpos recombinantes e expressão em cultura de células de Ovário de Hamster Chinês (CHO). Dissertação de Mestrado. Universidade de Brasília, 2002.

Ruuls S. R., Jeroen J., van Bueren L., van de Winkel J.G.J., 1, Novel human antibody therapeutics: The age of the Umabs, Biotechno, vol. 3,p. 1157-1171, 2008.

Sarkar B.R.S., Philip C.J., Yadav P.C.D., Transfusion medicine and solid organ transplantUpdate and review of some current issues, Elsevier, v169, p. 162-167, 2013.

Sercaz E.E., Berzofsky a., Immunogenicity of Protein Antigens: Repertoire and Regulation, Annu Rev Immunol, v.15, 821, 1987.

Serpieri F., Inocencio A., Oliveira J.M., Pimenta Jr A.,. Garbuio A., Kalil J., Brigido M.M., Moro A.M., Comparison of Humanized IgG and FvFC Anti-CD3 Monoclonal Antibodies Expressed in CHO Cells, Mol Biotechnol, vol.45, p. 218-225, 2010.

Schatz D.G., Ji Y., Recombination centers and the orchestration of $V(D) J$ recombination. Nature Reviews Immunology, vol.11, 2011. 
Silva, H.M., Vieira, P.M., Costa, P.L., Pimentel, B.M., Moro, A.M., Kalil, J., Maranhão, A.Q., Coelho, V., Brígido, M.M., Novel humanized anti-CD3 antibodies induce a predominantly immunoregulatory profile in human peripheral blood mononuclear cells, Immunol Lett, v.125, p.129-136, 2009.

van Oers M.H., Kersten M.J., Treatment strategies in advanced stage follicular lymphoma, Best Pract Res Clin Haematol., v24, n2, p187-201, 2011.

Vincenti F., Interleukin-2-receptor blockade with daclizumab to prevent acute rejection in renal transplantation. $\mathbf{N}$ Engl J Med, vol. 338, p. 161-165, 1998.

Waleed Alduaij and Tim M. Illidge The future of anti-CD20 monoclonal antibodies: are we making progress? Lande Biocience v.117, p. 2993-3001, 2011.

Wang Y.Z., Tian F.F.,Yan M., † Zhang J.M.,Liu Q.M.,Lu J.Y., Zhou W.B.,Yang H., Li J., Delivery of an miR155 inhibitor by anti-CD20 single-chain antibody into $B$ cells reduces the acetylcholine receptor-specific autoantibodies and ameliorates experimental autoimmune myasthenia gravis, Clinical and Experimental Immunology, v.176, p. 207-221, 2014.

Weiner L.M., Surana R., Wang S., Monoclonal Antibodies versatile plataforms for câncer immunotherapy. Nature Reviews Immunology, v10, p 317-327, 2010.

Xinyu X., Yun S., Yun C., Quingquing Z., Fan Y., Heng C., Young G., Mei Z., Liping Y., Tao Y., Inhibition of Increase Circulating Tfh cell by anti- CD20 monoclonal antibody in patients with Type 1 Diabetes, Plos One, v 8, inssue11, 2013. 
